
Digitized by the Internet Archive in 2010 with funding from

Research Library, The Getty Research Institute

http://www.archive.org/details/sylvafloriferash02phil 




\section{SYLVA FLORIFERA:}

THE

SHRUBBERY

HISTORICALI.Y AND BOTANICALLY TREATED.

YOL. II. 
LONDON:

Printed by A. \& R. Spottiswoode, New-Street-Square. 


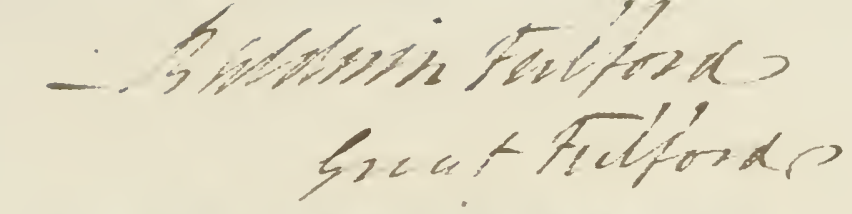

\section{SYLVA FLORIFERA :}

THE

\section{Shrubbery}

HISTORICALLY AND BOTANICALLY TREATED;

WITH

ODSERVATIONS ON THE FORMATION OF

ORNAMENTAL PLANTATIONS,

AND

PICTURESQUE SCENERY.

\section{By HENRY PHILLIPS, F.H.S.}

AUTHOR OF POMARIUM BRITANNICUM, AND HISTORY OF CULTIYATED VEGETABLES.

\footnotetext{
Sylva nemus non alta facit : tegit arbutus herban:

Rosmaris et lauri, nigraque myrtus olent.

Nec densa foliis buxi, fragilesque myrica,

Oid. Ars Am.

Jec tenues cytisi, cultaque pinus abcst.
}

IN THO VOLUMES.

TOL. II.

LONDON :

PRINTED FOR LONGMAN, HURST, REES, ORME, ANI BROWN, PATERNOSTER-ROW.

1823. 



\section{SYLVA FLORIFERA.}

\section{LABURNUM.-LABURNUM : CYTISUS.}

Natural order, Papilionacea, or Leguminose. A genus of the Diadelphia Decandria class.

In streaming gold."

" Nor might she fear in beauty to excel,

From whose fair head such golden tresses fell."

'THis beautiful alpine tree was known to the Greeks under the name of 'Avórup:5, and its emetic qualities gave rise to their proverb, Anagrin commovere, " to work one's own woe." It is observed that the bees avoid the flowers of this tree, whose leaves are so agreeable to the goat. Theocritus, the poet, who flourished VOL. II. 
at Syracuse, in Sicily, about 282 years before the Christian era, remarks, that the wolf pursues the goat with as 'much eagerness as the goat hunts for the laburnum; and Virgil has celebrated it for augmenting the milk of goats. Pliny tells us, that the laburnum belongs to the Alps, and that it was not commonly known in Italy when he wrote his Natural History. He says, the wood is white and hard; and that the bees would not even settle upon the blossoms of this tree.*

The laburnum has long graced the British gardens, as we learn from Gerard that it flourished in Holborn in 1596. What would be the astonishment of this excellent old herbarist, could he be recalled, to see each avenue of his garden formed into streets; houses erected on his parsley beds, and chimneys sprung up as thick as his asparagus; churches occupying the site of his arbours, and his tool-house, perhaps, converted into the British Museum, where is safely housed the lasting memorial of his labours. In vain would he now seek wild plants in Mary-le-bone, where each blade of grass is transformed into granite, and every hawthorn hedge changed for piles of bricks : carriages rattling where snails were formerly

* Book xri. chap. 18 . 
crawling. His ear would be assailed by the shrill cry of "Milk below," and the deep tone of " Old clothes," where he had formerly retired to listen to the melody of the early lark, or the plaintive tones of the nightingale.

6 A breath of unadulterated air, The glimpse of a green pasture, how they cheer The citizen, and brace his languid frame !"

Yet how careful have they been to keep it as distant as possible from thenarrow yard of our metropolitan church, which stands on one of the finest sites in the universe, as will be seen - when the age arrives that will level the buildings which obstruct the view of it from the Thames. Should the cathedral of Saint Paul's ever be seen forming the centre of a crescent, which would open to the south, and whose base would be washed by the noble but now obscured river, it would become the most splendid spot, and the most delightful promenade that the world could boast. What would not the citizens give for so fine and healthy a spot, where themselves and their families might breathe an air, scarce less healthy than that which they must now go many miles to enjoy? What wealthy citizen is there who would not contribute largely to see the finest church on the earth stand at the 
head of a lawn, which gradually ascends from the waves of his boasted river; and what situation could be so eligible for the erection of national galleries, libraries, and museums, as this would offer: - but let us return to the shrubbery; for

" The statesman, lawyer, merchant, man of trade, Pants for the refuge of a peaceful shade."

The laburnum was called Bean-trefoile tree in the time of Gerard, because the seeds are shaped like the bean, and the leaves like the trefoil. It had also the name of Peascod tree in that age, but which has long given way to that of the Latin Laburnum, which Haller says is evidently derived from the Alpine name, L'aubours. In French it is named Cytise des Alpes, Abours, and Faux ebenier, because the wood was often used as a substitute for ebony.

The laburnum is a tree of the third height, and flowers in the shrubbery from eight or ten to twenty feet in height. As it is of the middle stature, so should it generally form a centrical situation. Dark evergreens, of the larger kind, form a good back ground to this cheerful, flowering, and graceful tree, whose yellow pendent blossoms shine more conspicuously by the contrast. Its extending branches should wave their golden treasures 
over the snowy balls of the guelder rose, or the delicate tints of the Persian lilac; whilst the tall eastern lilac may dispute the prize of beauty with its gay neighbour from the Alps, and our native hawthorn's silvery petals shine not in vain ; for

"Thus is Nature's vesture wrought To instruct our wand'ring thought;

Thus she dresses green and gay,

To disperse our cares away."

We have introduced no tree that is more ornamental to our plantations than the laburnum; it relieves alike the gloomy clumps of mountain firs, and the borders of the forest shades; it enlivens the holly hedgerow, and embellishes the cottage garden. It would also become a profitable timber, were we to plant it for that purpose; for the wood is of a hard nature, and approaches near to green ebony. Mr. Boutcher tells us, that he saw a large table, and a dozen of chairs made of this wood, which were considered by judges of elegant furniture to be the finest they had ever seen. Its use for these purposes is common in France, but it has seldom been suffered to stand long enough in this country to arrive at any size. Mr. Martyn says, he has seen trees of the laburnum, in old Scotch gardens, that were fit to cut down for the use of 
the timber, being more than a yard in girth, at six feet from the ground; and these had been broken and abused, otherwise might have been much larger. This able writes: tells us, in his edition of Miller's Gardener's Dictionary, that the laburnum grows very fast, and is extremely hardy, and is well worth propagating upon poor, shallow soils, and in exposed situations.

His Grace the late Duke of Queensberry sowed a great quantity of the seeds of this tree upon the side of the downs, at his seat near Amesbury, in Wiltshire, where the situation was very much exposed, and the soil so shallow, that few trees would grow there; yet in this place the young trees were twelve feet high in four years' growth, and became a shelter to the other plantations, for which purpose they were designed. In neighbourhoods where hares or rabbits abound, these trees will require protection, as they will otherwise bark them in the winter ; and hence it has been suggested, to plant laburnum seeds in plantations infested with these destructive animals, which will touch no other plant so long as a twig of laburnum remains. Though eaten to the ground in winter, it will spring again the next season; and thus constantly supply food for this kind of game. A small 
sum laid out by a farmer in this seed, and judiciously sown in his hedges or coppices, would save his crops, as well as the planter's young trees.

Laburnums are recommended to be planted thick, for the purpose of drawing them up, to form hop poles, which are said to be more durable than those of most other wood. Matthiolus speaks of its being used for making the best bows. It is found to char remarkably well; and the wood is esteemed also for making pegs, wedges, musical instruments, and a variety of purposes for which hard wood is required.

The laburnum is easily propagated by seed, which it produces in great plenty. It is usually sown in the month of March ; but young trees may generally be found in abundance where the trees have scattered their fruit. In forming plantations for poles or timber, the seeds should be sown where they are intended to remain; but for the shrubbery, or ornamental plantation, they should be removed, and their roots shortened, which will cause them to flower more abundantly.

Children should be cautioned not to eat the seeds in the green state, which are violently emetic and dangerous. 


\section{LARCH. - PINUS LARIX.}

Natural order, Coniferce. A genus of the Monœcia Monadelphia class.

"The swain, in barren deserts, with surprise Sees larch trees spring, and sudden verdure rise."

The face of our country has, within the last thirty years, been completely changed by the numerous plantations of larch that have sprung up on every barren spot of these kingdoms, from the southern shores to the extremity of the north, and from the Land's End to the mouth of the Thames. So great has been the demand for young trees of this species of pine, that one nurseryman in Edinburgh raised above five millions of these trees in the year 1796. We have introduced no exotic tree that has so greatly embellished the country in general. Its pale and delicate green, so cheerfully enlivening the dark hue of the fir and pine, and its elegant spiral shape, contrasting with the broad spreading oak, is a no less happy contrast; whilst its stars of fasciculate foliage are displayed to 
additional advantage, when neighbouring with the broad-leafed æsculus, the glossy holly, the drooping birch, or the tremulous asp.

The larch seems created for society, as it shines with additional lustre amidst trees of every cast and character.

"Like some enchantress, with her magic wand, In treasures new she decks the smiling land."

The thanks of the present age, and the gratitude of the next, are and will be given most sincerely to those noblemen and gentlemen who have so greatly contributed to the beauty of our rural scenes, and the profit of themselves and their heirs. These plantations display a most noble love of country, and generous provision for posterity; and that these liberal minded planters may long live to enjoy the beauties they have created, and reap the harvest they have sown, must be the fervent wish of every good Briton.

"Perhaps some sire, in life's declining year, Those woods revisits, to his memory dear ; In infant days that planted by his hand, Now wave aloft, and decorate the land.

For him the groves a smiling aspect wear, And fields and flowers his transport seem to share !"

The larch was considered by the ancients as amongst the most valuable timber trees, 
particularly for the purpose of building, being almost imperishable, and less inflammable. than any other wood; and we read of no tree that exceeded it in height. Amongst the timber which was brought to Rome for the purpose of building the bridge called Naumachiaria, about the 20th year, A. D., was a larch that measured two feet square in thickness throughout, from end to end, and was of the extraordinary length of 120 feet; the tree must therefore have been not less than from 130 to 150 feet in height. Tiberius Cæsar would not allow this wonderful trunk to be used in the erecting of the bridge then building, but commanded it to be placed where all persons might see it as a curiosity; and where it remained for about thirty years, until Nero employed it in building his vast Amphitheatre. Amongst the Romans, the larch was employed, in preference to every other kind of wood, in buildings where strength and durability were required. *

Pliny tells us, that the larch was not found to decay in buildings like other pine timber; and that it burnt more like a stone than wood, never causing flame. 'This quality of the larch was not unknown to Julis, as he calls it lignum igni impenetrabile.

* Pliny, book xvi. chap. 4.0. 
This timber seems to have been scarce in Rome during the Augustine age, as M. Vitruvius Pollio, a celebrated architect of that period, attributes the sudden decay of buildings erected in his time, in a great measure to the want of larch in the neighbourhood of Rome, it having been exhausted before his time; and the expense of bringing it from a distance, in those early days, would have been too great for common purposes.

The larch is a native of the south of Europe and of Siberia; it grows abundantly in Switzerland and in Provence, \&c. : and as it must naturally create considerable interest in the generation that is rising with it in these kingdoms, we shall endeavour to point out the very spot on which it first took root, and the circumstance to which the larch owes its birth; and should the veracity of our account be disputed by any critical reviewers, we will call up all our classical and antiquarian friends to defend a point of so much importance, as that of connecting a beautiful idea with a beautiful tree. Behold then, in the graceful larches, the affectionate sisters of the ambitious Phaeton, who were metamorphosed into these trees, whilst sorrowing round the tomb of Apollo's son on the borders of the Po. 
"And beat their naked bosoms, and complain, And call aloud for Phaëton, in vain :

All the long night their mournful watch they keep, And all the day stand round the tomb and weep.

Four times revolving the full moon return'd, So long the mother and the daughters mourn'd; When now the eldest, Phaëthusa, strove To rest her weary limbs, but could not move; Lampetia would have help'd her, but she found Herself withlield, and rooted to the ground: A third in wild affliction, as she grieves, Would rend her hair, but fills her hands with leaves; One sees her thighs transform'd, another views Her arms shot out, and branching into boughs. And now their legs, and breasts, and bodies stood Crusted with bark, and hard'ning into wood."

As the poplar has been found so abundantly in the neighbourhood of the river Po, it has been conjectured by some that it was that tree into which the daughters of Clymene were transformed; but in a medal of Publius Accoleius Lariscolus, the three sisters are represented as transformed into larches; and it would certainly seem that Ovid rather meant the larch than the poplar, from the tears of the sorrowing trees, which agrees with the former, but not with the latter.

Inde flumt lacrymce: stillataque sole rigescunt

De ramis electra novis: quce lucidus amnis

Excipit, et nuribus mittit gestanda Latinis.

"The new-made trees in tears of amber run,

Which, harden'd into value by the sun, 
Distil for ever on the streams below :

The limpid streams their radiant treasure show,

Mix'd in the sand; whence the rich drops convey'd,

Shine in the dress of the bright Latian maid."

The Greeks call the larch $\Lambda \alpha^{\prime} \rho \xi$, and the Latins after them Larix, from whence the Italian and Spanish name Larice, and the German Larchenbaum, from which we have evidently derived the English name. The French call it Mélèze. The larch is known as the only tree whose foliage is deciduous, that produces cones, as all the other species of pines are evergreens. The larch sends out its leaves in the month of April, of a beautiful pale and yellowish green, shaped like the narrow leaf of grass, and in little clusters of about forty each, disposed like the hairs of a painter's brush, but which afterwards expand into rosettes or stars, which drop off in the autumn. The flowers appear also in April, and generally are of a fine crimson colour, which at first gives them an appearance something like small strawberries; but the male flowers extend in length as the pollen ripens. The female flowers are collected into egg-shaped obtuse cones, which when matured are from one to two inches in length, and whose scales protect the seeds in the same manner as the cones of the fir and cedar, \&c. 
The larch was cultivated in this country as early as 1629, as it is mentioned by Parkinson, in "The Corollary to his Orchard;" but so late as 1656 , when the second edition was published, it was but little known; and as the tree is now more generally distributed over the country since his account of it, we shall give his own words, which were dictated for, and dedicated to the Queen of the unfortunate Charles the First, to whom Parkinson was herbalist. 'This author says, "The larch tree, where it naturally groweth, riseth up to be as tall as the pine or firre tree; but in our land being rare, and nursed up but with a few, and those only lovers of rarities, it groweth both slowly and becommeth not high, the bark hereof is very rugged and thick, the boughs and branches grow one above another in a very comely order, having divers small yellowish knobs or bunches set thereon, at several distances; from whence do yearly shoot forth many small, long, and narrow smooth leaves together, both shorter and smaller, and not so sharp-pointed as either the pine or firre-tree leaves, which do not abide the winter as they do, but fall away every year, as other trees which shed their leaves and gain fresh every spring: the blossoms are very beautiful and delectable, being of an 
excellent fine crimson colour, which, standing among the green leaves, allure the eyes of the beholders to regard it with the more desire : it also beareth, in natural places, (but not in our land, that I could hear,) small soft cones or fruit, somewhat like unto cypresse nuts, when they are green and close."

It was not likely that this tree should have been cultivated during the commonwealth, which was the age for destroying our forest timber; but at the Restoration of Charles the Second, Evelyn stood forth as the champion of the British Sylva, and tells the nation, that there had flourished not long since a larch tree near Chelmsford, in Essex, of good stature, "which," says he, "sufficiently reproaches our not cultivating so useful a material for many purposes where lasting and substantial timber is required."

Mr. Evelyn then tells us that the young larch tree that he had brought up with much care in his garden, was supposed to be dead by his gardener when the leaves fell off, which proves how little the nature of the larch was known in England even at that time.

Mr. Drummond had some larches planted in Scotland as long back as 1734; and two larches were planted on the lawn of the Duke of Atholl's seat at Dunkeld, in Perthshire, in 
the year 1741, the largest of which, in 1796, measured, at one foot eight inches from the ground, eleven feet eleven inches in circumference, and at twelve feet from the ground, eight feet two inches, at twenty-four feet the circumference was seven feet seven inches; at which time some of the younger larches measured upwards of one hundred feet in height. These plants were originally sent from London in earthen pots, rather as a curiosity than from any expectation of their excellency; but they may now overlook whole forests of this timber, of which they have been the parent plant.

The larch having been ascertained to be of a hardy nature and quick growth, thriving better on a poor hungry soil than in a rich earth, and the utility of the timber being universally acknowledged, these considerations induced the Society for the Encouragement of Arts, Manufactures, and Commerce, at London, to offer both honorary and pecuniary rewards for the propagation of this tree; and as long back as 1788, three gold medals and a premium of thirty pounds had been bestowed by the Society for planting larches, and giving an account of the wood; and there is every prospect that the encouragement given by that Society will be the means of 
enriching these kingdoms in a few years, by saving the large sums which are annually sent out of the country for pine timber. Amongst the earliest planters of larch we notice the Duke of Atholl, who, we are told by Dr. Anderson, planted 200,000 every year; and by an account which we have lately been favoured with, it appears that his Grace planted $1,102,367$ in the winter of 1819 and the following spring. They were planted on 556 acres, or 548 Scotch acres, at 2,000 per Scotch acre, at the rate of about 30,440 daily, for thirty-six days, being one day's labour for 1,054 men, or thirty men for the thirty-six days. The expence of planting was about five hundred and seventy pounds, or twelve shillings and sixpence per Scotch acre. The present Duke of Atholl has had the satisfaction of seeing a frigate of thirty-six guns built en-tirely of larch timber of his own planting, which we believe is more than any other individual in the universe can boast of. It was launched from the stocks at Woolwich, about three years back, being named the Atholl. At the same time a frigate, named the Niemer, was built of Riga fir; and as they are both of the same size and form, and are destined to the same station, the government will have a fair trial of the comparative value of these 
timbers. Too much praise cannot be bestowed on his Grace in surmounting the obstacles which were continually thrown in his way by contractors and other interested persons, who endeavoured to prevent this important experiment from being made. A brig, of 171 tons, called the Sarah, has also been built at Perth, of larch timber, from the forest of his Grace the Duke of Atholl. The Diana steam-boat, which plies between London and Richmond, is also composed of the same timber ; it was built by Evans of Rotherhithe.

The Duke has some beautiful cabinets formed of this wood, in his house in Great George-street, Westminster ; and we have lately seen a table made from one of his Grace's larches, which, in point of beauty and closeness of grain, is nearly equal to those formed from the root of the yew-tree. In 1787, and the following year, the Bishop of Llandaff planted 48,500 larches on the high grounds near Ambleside, in Westmoreland. John Sneyd, Esq., of Belmont, in Staffordshire, planted 13,000 larches between the years 1784 and 1786, and 11,000 more in 1795 . W. Mellersh, Esq., of Blyth, planted 47,500. Joseph Cowlishaw, of Hodsock Park, Esq., planted 27,400. Richard Slater Milnes, Esq., of Foyston, near Ferrybridge, in Yorkshire, 
planted 200,000, about four years old plants. In the same county, Mr. George Wright planted at Gildingwells 11,573. Thomas White, Esq., of West Retford, in Nottinghamshire, planted 13,000 about the year 1789 . The late Earl of Fife planted 181,813 in the county of Moray, in Scotland. In 1791, the Rev. T. Dunham Whitaker, at Holme, in Claviger, in the county of Lancaster, planted 64,135 ; and in the same year Thomas Gaitskell, Esq., of Little Braithwait, in Cumberland, planted 43,300, on fifteen acres of high land. The same spirit for planting the larch has continued down to the present time, and extended to all parts of the country where the land has not been thought more valuable for other purposes. In 1820, the London Society for promoting Arts, \&c., presented the gold medal to his Grace the Duke of Devonshire, for planting 1,981,065 forest trees, 980,128 of which were larch.

The larch-tree is now found to ripen its seed perfectly in England. The cones should be gathered about the end of November, and kept in a dry place till the spring; when, if spread on a cloth, and exposed to the sun, or laid before the fire, the scales will open and emit their seeds. These seeds should be sown on a border exposed to the east, where

$$
\text { c } 2
$$


the morning sun only comes on it, as the plants do not prosper so well where the sun lies much on them. The young plants may be pricked out into other beds in the autumn as soon as their leaves have fallen off, and the distance of six inches each way is the space recommended between them. In two years they will be ready to plant where they are intended to stand.

When the young trees are planted out for good, they need not be more than eight or ten feet distant from each other; but they must be planted closer on exposed situations : and it is recommended not to dig the ground between young larches; therefore the weeds should be drawn by the hand, or cut down by the hoe, whilst the plantation is young.

Plants which are intended for exposed situations should not be taken from warm sheltered beds, which naturally cause them to be more tender. It has been proved that those larches planted in the worst soil, and in bleak places, have thriven the best; for where trees of equal size have been planted in good earth at the same time, the others on cold stiff land have in twelve years been twice the height of those planted in good ground. The Bishop of Llandaff informs us, that from many experiments made by himself, and col- 
lected from others, he finds the annual increase in circumference of the larch, at six feet from the ground, to be one inch and a half, on an average of several years ; and that this inference has been drawn from the actual admeasurement of larches in different parts of England and Scotland, and of different ages, from ten years old to fifty. Mr. Hart says, the larch grows slowly the first four years; but in twenty years it will exceed the fir-tree, both in height and circumference, that is double its age. Eight trees being measured in the spring and autumn of the year 1794, the average of their increase in height was nearly three feet nine inches and a quarter; and one of them increased three inches in circumference at two feet above the ground. In another plantation, the trees at eight years' growth measured above twenty feet in height on an average: the trees were from six to nine inches high when planted. At twelve years old they measured, on an average, from thirtyfour to thirty-six feet in height; and this increase is continued until the timber is nearly ready to be felled.

In the Memoirs of the Royal Society of Agriculture at Paris for 1787, there is an account of some birch-trees in some parts of 
Dauphiné, and in the forest of Baye, in Provence, which two men could not grasp.

Of the qualities of the larch wood we have so much to add to what we have already stated, that should any one read our account who has plantations of this timber, and is not yet acquainted with its valuable properties, he will naturally seem to increase in riches as he proceeds from line to line.

Dr. Anderson says it is possessed of so many valuable qualities, that to enumerate the whole would appear extravagant hyperbole.

We have already noticed what the ancients have said of this timber's resisting the flames; in addition to which Mr. Hart observes, that there is perhaps no instance of the cottages in Carniola being set on fire, although their roofs are covered with boards of this wood, and they are so careless as to throw flaming firebrands on them. Matthiolus notices the incombustibility of this wood; but says, unwilling as it is to take fire, yet it is nowise difficult to burn it in kilns, glass-houses, and furnaces belonging to iron-works, when once the inside of these receptacles is rendered intensely hot. Such is the practice in the iron-works of Stiria and the bishopric of 
Trent, where this wood is of singular use, when there is heat sufficiently fierce and strong to penetrate it forcibly.

It is known that the larch timber will resist water in a still stronger degree than it is able to endure the fire, as when employed under water, it remains almost to eternity without rotting. The piles of this timber on which the houses of Venice were built many hundred years ago, are still found as fresh as when first put in. Stakes of it have been tried in the decoys of Lincolnshire, which, between wind and water, have already worn out two or three sets of oak stakes, and do not yet discover any symptoms of decay.

Dr. Pallas, in his survey of the Russian dominions in Asia, observed several tumuli in Kamtschatka, reared at a period so remote, that none of the present inhabitants had any tradition respecting their origin. The platform was covered by larch wood, over which the mound of earth was raised; and the wood was found to be uncorrupted.

It is said that planks of larch are superior to those of oak for many purposes in shipbuilding. At Archangel, ships of the line are built of this timber; and at Venice it is also employed in naval architecture, especially in the lighter parts of the upper works, 
but not where massy pieces of timber are required, on account of its weight. It resists the intemperature of the air more than any wood known in that country, and therefore is much used for outer gates, poles, \&c. In some of the old palaces at Venice there are beams of larch as sound as when placed. Mons. le President de la Tour d'Aigues says, in 1787, " I have in my castle of Tour d'Aigues beams of twenty inches square, which are sound, though upwards of two hundred years old."

We are assured that when used for hoppoles, one set of these would outlast two or three sets of ash; and as it will bear so great a weight, it is particularly adapted for the supporting the roofs in mines, \&e.

There is not a branch or twig of the larch, says Dr. Anderson, that may not be put to some useful purpose. The larger branches may be employed in fencing, and the smaller brush for filling drains, and for fuel. In drains it is more durable than any other. wood; and though the timber will not readily burn, yet the brush is found to make a fire almost equal to the billets of many other trees. The Italians use it for picture-frames, because no other wood gives gilding such force, brightness, and, as it were, a sort of 
natural burnish; and this is said to be the grand secret why their gilding on wood is so much better than ours.

On account of its bitter nature worms will not attack it, and it is not subject to warp like most other panels of wood; and, being extremely solid, it admits of a fine polish or smooth firmness, and is therefore particularly adapted for artists to paint on, as it throws forth the colouring better than any other wood. It is the wood which the incomparable Raphael chose to bear the strokes of his pencil, and his celebrated picture of the Transfiguration was painted on panels of this timber; and let us hope that we have British Raphaels growing up with our British larches, who will, by their enchanting art, show us that they can metamorphose this wood into beautiful figures, as easily as Ovid transformed the sisters of Phaeton into these trees.

The artist not only finds his palette and panel in the larch, but this tree also bleeds freely to furnish him with turpentine and varnish for his paint, and lends its assistance also in furnishing a material for the frame.

It is the larch which produces the turpentine known by the name of Venetian turpentine, which is obtained by making incisions in the trunk of the tree, at about three feet 
from the ground: narrow troughs of about twenty inches long are fixed in the incisions, to convey this liquid into receivers below. The principal season for collecting this resinous juice is from the end of May to September. As our larch-trees become aged, we may fairly calculate on saving much money to the country by using turpentine extracted from our own woods. It is only after the tree has attained the thickness of ten or twelve inches in diameter, that it is thought worth while to collect the turpentine; and from that time, during 40 or 50 years, if it continue in vigorous growth, the tree will continue to yield annually from seven to eight pounds of turpentine.

Martyn calculates that an English acre will contain 682 trees, at the distance of eight feet from each other. Suppose the annual produce to be six pounds a tree, on an average, and the price to be no more than two-pence the pound, the value of the produce would be $3 l .4 s .2 d$. the acre.

It was from old larch-trees that the ancients gathered the agarick, so celebrated by their medical writers; but this fungous substance is now fallen into total disuse as a medicine in this country, though it is still used in northern countries as an emetic in intermitting fevers. 
The Tunguses use it to dye the hair of the rein-deer; and the women, in some parts of Siberia, wash themselves, and even their linen with it, as it is found to be of a saponaceous quality.

It is now calculated that the Highlands of Scotland will in the next age be able to furnish the whole commerce of the island with timber for its shipping; and it is still to be regretted that so much barren land should be suffered to remain unplanted with this and other timber as we find in the counties of Kent, Sussex, and Hampshire ; all of which being connected with some dock-yard, ought not to lie useless to the community when the soil could be so advantageously employed.

Plantations that are formed exclusively of larch destroy the heath and all other vegetation; but, after a few years, a fine grass springs up, that is so valuable for grazing, that it has been let from ten shillings to five pounds per acre for this purpose, which, previous to its being planted, would not bring as many pence. Sir John Hay, Bart., and the Duke of Atholl, have had extraordinary instances of this advantage; but it is observed, that when Scotch firs, or other trees, are mixed in the plantations, this benefit is not derived. 
COMMON LAURRL. - PRUNUS LAURO. CERASUS.

Natural order, Ponacea; Rosacea, Juss. A genus of the Icosandria Monogynia class.

"In various hues; but chiefly thee, gay green! Thou smiling nature's universal robe!

United light and shade; where the sight dwells With growing strength, and ever new delight."

Tномson's Spring.

THis eastern evergreen, which exhibits its large glossy leaves in all our shrubberies, and contributes so considerably to the vernal appearance of our winter walks, seems to have escaped the notice of the ancient Greek and Roman naturalists, although it is a native of the same latitude and longitude from whence Lucullus procured the cherry-tree, which was thought worthy to be placed in the most conspicuous situation amongst the Armenian treasures which he exhibited in his triumphal entry into Rome.

The commion laurel came into Europe with the name of Trebezon curmasi, which means the plum or date of Trebisond; and as its 
leaf something resembled the ancient laurus or bay, it was supposed to be a species of that plant; and as the fruit bears resemblance to our small black cherry, it was called the Bay cherry, and Laurocerasus, Laurel cherry.

As it now seldom has any name added to that of laurel, many persons mistake this shrub for the laurel so celebrated of old for crowning both the victor and the poet; and this error is more frequent, from our having changed the name of the laurus into bay.

The common laurel was first made known to this part of the world by His Excellency David Ungnad, who, whilst ambassador from the Emperor of Germany at Constantinople, sent, in the year 1576, a collection of rare shrubs and trees to Clusius, the celebrated botanist, at Vienna; but owing to the severity of the weather whilst on their journey, and the carelessness of those who brought them, they all perished, excepting the horse-chesnut and the laurel, and Clusius relates that the latter was almost dead when it arrived. He put it into a stove in the same state as it arrived, and in the same tub of earth. The following spring he took it out, cut off the dead and withered branches, and set it in a shady place. In the autumn it began to shoot from the root; and he then 
removed the living part into another tub, and attended it with great care. As it advanced he laid down the branches which took root, and he distributed the plants amongst his friends and men of eminence. Thus the laurel became known throughout Europe. Clusius's plant died without flowering; but another which he gave to Aicholtz flowered in May 1583; and also another a few years afterwards with Joachim Camerarius at $\mathrm{Nu}-$ remberg. *

The laurel is not mentioned by Gerard in 1597, and we may therefore conclude that it was not then known in England. Parkinson says, in his "Garden of Pleasant Flowers," which was published in 1629, that it grew in the garden of Master James Cole at Highgate, where it had blossomed and ripened fruit, and that it was preserved by throwing a blanket over it every winter. Cole was a merchant in London, who appears to have bestowed much pains and expense in collecting rare plants. Gerard calls him his "loving friend," on which account we conclude he had not received the laurel when he published his Herbal ; yet we find that Cole, as well as Gerard, was in friendly correspondence with

* Clus. Hist. 
Clusius, and we cannot well account for the length of intervening time before they received plants of the laurel. Clusius died in April 1609; and, as Parkinson says, in 1629, Cole's laurel had then "flowered divers times, and borne ripe fruit also," he must have received it early in the seventeenth century.

Parkinson tells us, that he had procured the laurel from Master Cole, and that he had also received its seed from Italy, under the title of Laurus regia, the "King's bay ;" but it having no affinity with the bay, Bellonius named it Laurocerasus, "and I should," says Parkinson, "have placed it in my orchard amongst the sorts of cherries; but the beautifulnesse of the plant caused me rather to insert it here, in the Garden of Pleasant Flowers."

Evelyn says, that he was told by a noble personage, that the laurel was first brought to England by the Countess of Arundel, wife to Thomas Earl of Arundel and Surry, to whom this country is indebted for the Arundelian Marbles.

In referring to the history of this ancient family, we find that the Countess of Arundel set out for Italy in 1614, for the purpose of accompanying her two sons to England. It is, therefore, probable that this evergreen 
might have been introduced by her at that time, as it is noticed that wherever she passed she was treated with honours that had never, been before paid to an English subject.

The laurel was become common in this country in 1664, as Evelyn observes, that "from the use we commonly put the laurocerasus, the cherry bay, to, it seems as if it had been only destined for hedges, and to cover bare walls." Ray, in 1688, relates, that it was then very common in English gardens and plantations ; that it flowered and fruited very well; was very patient of cold, and braved our winters even in an exposed situation.

This evergreen grows naturally on the eastern borders of the Black Sea, particularly in the vicinity of Trebisond, as also on the Caucasian mountains, which extend from the Black to the Caspian Sea. It grows also on some mountains in Persia, and in Crimea. It seems to love a moist soil, and to thrive in our atmosphere much better than in most parts of the Continent. At the present time it is even rare in the gardens around Paris; and a very small plant of it at the tomb of Delille is all we observed at Père la Chaise. It is the Cerasus lauro-cerasus of M. Jussieu, the celebrated botanist; but it is commonly 
known in France by the name of Laurieramandier, Almond-laurel, because the leaves give the flavour of bitter almonds : and it is also called Laurier-au-lait, Milk-laurel, from its being used to flavour milk. It was formerly much used in this country to give a flavour to puddings and custards, \&c.; but this practice is much less frequent since it has been ascertained to be a deadly poison. We should therefore caution all persons against its use, and particularly cooks ; for in case of accident, they would be tried for the murder of the sufferer as much as if they had used any other poisonous drug. Dr. Darwin says, "The distilled water from laurel leaves is, perhaps, the most sudden poison we are acquainted with in this country. I have seen about two spoonfuls of it destroy a large pointer dog in less than ten minutes. In a small dose it is said to promote intoxication. On this account there is reason to believe it acts in the same manner as opium and vinous spirit; but that the dose is not so well ascertained." As our shrubbery is meant to amuse, we forbear mentioning the dreadful consequences that have ensued from the baneful juice of this leaf; but we feel it a duty to caution those who may have been in the habit of using it, particularly as custards and puidVOL. II. 
dings are generally eaten by children, whose constitutions may suffer through life from the injury done them by this mode of giving. a relish to their diet.

The laurel is rather a heavy than a graceful shrub, but the beauty of its green leaves will always ensure it a situation in ornamental plantations. The foliage is of the most agreeable yellow green, being brighter than that of either the orange or lemon; and as the greater number of evergreen plants are of a dark or bluish green, and many of them with a tint of reddish brown, nothing in point of colour can therefore be more desirable than the laurel to relieve the sameness which would otherwise too often predominate in our winter greens. The common laurel has flowers in April and May, and although small; their appearing in clusters has a good effect, particularly when the trees have acquired age, so as to produce their white petals in abundance.

The laurel, when trained as a tree with one stem, has a very superior appearance to the common bush, particularly when it can be carried to a considerable height before it branches out; and to obtain this effect more speedily, it is recommended to graft the laurel on a common cherry stock, or upon 
that of the Cornish cherry, which it generally unites better with than the former.

The laurel should not advance too near the foreground in the shrubbery, but the plants should be sufficiently numerous to give a cheerful contrast in the winter months, and it is well adapted to shut out the appearance of disagreeable objects.

It forms the most beautiful foreground to large plantations, when planted by the hand of taste; but we condemn the mode of bordering clumps and groups with it, which give the idea of a frame to the landscape. It should sometimes intermix with, and sometimes advance from the plantation, so as to avoid the idea of a fence; the grouping must also depend on the formation of the ground, and the situations where we wish to give light or shade.

Where holly abounds naturally, or is cultivated, a mixture of laurel gives great relief; and as it is a shrub of such easy propagation, it ought to be found in considerable abundance in all woodland scenes.

At Woburn Abbey, the seat of his Grace the Duke of Bedford, there is a hill covered entirely with laurels, which are grown to a considerable size; and in the plantations of the

D 2 
Earl of Chichester at Stanmore,near Brighton; we have seen a hedge of laurel about 220 yards in length, where they have grown to the height of thirty feet, and some of the principal trunks measure three feet in circumference, at about two feet and a half from the ground. These trees have been pianted about fifty years, and have never been injured by the frost.

The laurel approaches so near in appearance to the orange tree, that when planted in the shrubbery as a screen for defending the citrus tribe, and a few standard laurels interspersed, a very inconsiderable number of these tender trees may be made to give the effect of a plantation of orange trees, at the season when they can be removed from the orangery, or the conservatory.

It will generally be found that the laurels raised from seed produce the finest plants, particularly for standards, as those obtained from cuttings or layers incline more to a horizontal growth, and produce a greater number of lateral branches, but which are also desirable for some situations in the shrubbery. The berries are seldom perfectly ripe before October, when they should be immediately sown in a dry soil, at about two inches deep, 
and the bed should be guarded from frost by any light litter, such as pease, haulm, \&c. being thrown over it. The young plants will appear in the spring, and may be transplanted in the following autumn.

Cuttings should be planted as soon as the ground has been moistened by-the autumnal rains, which generally happens in the month of September. The cuttings must be the same year's shoots, with a small part of the former year's wood at the bottom ; a soft loamy soil is recommended, and they should be planted about six inches deep, and the earth should be pressed tight to the plants.

The common laurel is not without advocates for its medicinal properties; but on account of its known poisonous quality, we strongly decry the use of it, excepting by the advice of those whose time has been devoted to the study of medicine; and with them it is well known that the most beneficial effects are often produced by means of plants which would prove the most baneful in the hands of the ignorant. Linnæus informs us, that this plant is commonly and successfully used in Switzerland for pulmonary complaints. Langrish mentions its efficacy in agues.

Baylies found that it possessed a remarkable D 3 
power of diluting the blood; and from experience recommended it in all cases of disease supposed to proceed from too dense a state of that fluid, adducing particular instances of its efficacy in rheumatism, asthma, and schirrous affections. 
Natural order, Dumosce; Caprifolia, Juss. A genus of the Pentandria Trigynia class.

"Now, all amid the rigours of the year, In the wild depth of winter, while without The ceaseless winds blow ire"

Flora garnishes the cymes of the laurestine with hardy and modest flowers, which seem to say, "I'll tarry with you till your friends return, and cheer the scene with my pale pink buds and pure white petals," with which it ornaments the shrubbery from November's dreary month to the time that Boreas lends to March his strongest breath. We know not how this pretty winter flower stands in the Oral language of the Turks, but we find it emblematical of those British fair who desert the brighter scenes of society to cheer the sorrowing day of the lone widow, or cause the bereft parent to mourn his lost hope with less anguish. We will welcome 
thee, therefore, little laurus, in the shrubbery, even when the quieen of flowers displays her "blushing and odorous petals to the sun; because we know thou wilt come with all thy charms to make our winter walks more gay: and much it must be regretted, that thy mild charms could not detain the great Napoleon to thy native Elba; then many a widowhood would have been prevented, and the name of Waterloo happily never known to the fatherless child of many a sorrowing mother.

The laurestine grows naturally also in many parts of the south of Europe, Spain, Portugal, and it is likewise found wild in Barbary. Old authors give it the name of Laurustinus, from a supposition that it was a smaller species of the bay, laurus; they therefore added the word Tuyos, or Turvos, tine, or tiny, small. The Greeks

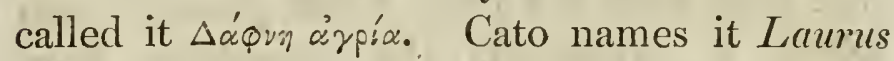
sylvatica; but Pliny says it was thought not to be a laurel in his time.

We are not able to state the exact time when it was first introduced to this country, but Gerard says, in 1596, that it then grew and prospered very well in his garden at Holborn. He calls it the "Wilde baie tree," and "Laurus timus."

The Italians call it Lauro salvatico, the 
Spaniards and Portuguese Una de perro, Follado, and Durilio; the French Laurier sauvage, the Dutch Laurus boom, and the Germans, Lorbeerbaum.

We have several varieties of this winterflowering shrub, all of which are desirable in the shrubbery, as the branches are sent out close to the earth, and take off the naked appearance which would be otherwise conspicuous in the winter months. Where it is desirable to form clumps of evergreens, on lawns, this is a desirable plant, as it completely obscures the bare trunks of taller growing plants, and blossoms so abundantly when all other shrubs have done flowering. It mixes well with the common laurel, as its leaves are of so different a tint.

It has been frequently noticed, that those trees which are raised from seed are hardier than others that are propagated by layers; but where it is intended to cover the ground beneath tall trees, we should recommend the plants raised by layers, as they will run on the earth in such situations like the ivy, and take root as they run. We found this shrub propagating itself in this way to a considerable extent in a plantation near Ryde, in the Isle of Wight, and we have often noticed its fondness for the sea air. 
The autumn is the best time for laying down the branches, which will be well-rooted, and ready to transplant by the following autumn.

Although the blossoms are the most hardy of any plant we introduce into the shrubbery, yet the laurestine is often injured by the severity of the weather, particularly when it is trained up with a naked stem; for as the sap must naturally rise when the tree is in the active state of forming its flowers and seed, it is naturally more susceptible of the frost, and those shrubs of this kind, which have their principal stem protected by branches and leaves, suffer less; and even when the great severity of the winter has killed the branches, we often find vigorous shoots sent forth from the stem when the old wood has been removed.

The berries of the laurestine arevery hot, and inflame the fauces violently; yet we find the starlings frequent this shrub, and devour the berries with as much avidity as the blackbird and thrush do those of the mezereon, which are of a similar nature. 


\section{LILAC. - SYRINGA.}

Nalural order, Sepiarice; Jasminece, Juss. A genus of the Diandria Monogynia class.

"T The lilac, various in array, now white,

Now sanguine, and her beauteous head now set

With purple spikes pyramidal, as if

Studious of ornament, yet unresolved

Which hue she most approved, she chose them all."

Cowper.

THE delightful sensation which the lovely tints of this elegant flower, and its fragrance, produce on us in the month of May, has been compared to the first emotions of love, for nature seems to have ordained that mortals should not be permitted to see the one or feel the other with indifference; for who can behold the flexible and modest, yet dignified clusters of this charming flower, whose colours vary at every movement, and so sweetly descend from the finest violet down to the silvery white, without regretting the short duration of so divine a gift.

Perhaps we have no flower that gives, or an imagination strong enough to conceive, 
greater harmony than is afforded in the happy gradation of colour from the purple bud to the almost colourless flower of these charming groups, around which the light plays and dissolves itself into a thousand shades, which all blending in the same tint, form that incomparable combination that rivets the attention of the most indifferent observer, and throws the painter into despair. We are told Spaendonk himself dropped his pencil before a bunch of lilac; for Flora seems to have designed the thyrsi of the lilac to please the artist by their delicacy, and to tantalize him by their varying tints.

The harmony of colours is so complete in the lilac, that when we place a bunch of the white flowers on a branch of the purple variety, an offensive harshness is instantly observed; nor will the more delicate green of the first kind assimilate with the purple tyrus of the latter, without displeasing the eye.

In the Floral language of the East, where this flowering shrub is a native, and where spontaneously

\section{-_ "the lilac hangs to view}

Its bursting gems in clusters blue,"

they have made it an emblem of the forsaken, because it is the flower that lovers offer their 
mistresses when they quit them; but in this climate, where the charm of the fair is as powerful as this flower is agreeable, the swain is kept in constant fear of receiving the lilac.

However ungallant the Persian beaux may be in giving the lilac, they are not deficient in complimenting the fair in their language, as their expression for a fine woman and a beautiful flower is the same. Lilac, or lilag, is a Persian word, which simply signifies a flower, but which Europe has given to the shrub it has taken from the ancient Elamites; and from the flower we have given name to one of our most delicate compound colours.

That a plant of the tropical climes should be so hardy as to stand the severest winters of the greater part of Europe is admirable in the lilac. Its easy propagation, and speedy growth,are no less conspicuous than its beauty, and which have contributed to its rapid distribution throughout not only the temperate but even some of the colder parts of Europe; for it has naturalized itself in Scotland and in the mountains of Switzerland, and it is now found in the forests of Germany, although it was unknown in this quarter of the globe before the year 1562, when Angerius de Busbeke obtained it from the East, and transported it from Constantinople to Vienna, whence he 
had been sent ambassador from the Emperor Ferdinand I. to the Sultan Soliman.

The generic name of this plant, Syringa, is derived from the Greek $\Sigma$ vgı when the pith is taken from the wood it formed pipes like those which Pan made of the reeds into which the nymph Syrinx was transformed.

"6 'Thou,' he said,

- Who canst not be the partner of my bed, At least shall be the consort of my mind, And often, often to my lips be join'd.'

He for'm'd the reeds, proportion'd as they are, Unequal in their length, and wax'd with care,

They still retain the name of his ungrateful fair."

Ovid.

Hence as syrinx and syringa meant a pipe, the lilac was called the Pipe-tree when first known in England; and under that name Parkinson writes of it in 1640, and Roy in 1665. Although Gerard says, in 1597, "The later phisitions do name the blew pipe-tree Lillach, or Lilac, and some Syringa." This author tells us, that the lilacs were then growing in his garden in very great plenty, where they flowered in April and May: and he adds, " but as yet they haue not borne any fruite in my garden, though in Italie and Spaine their fruite is ripe in September ;" from which we learn it was then common in Europe; but we 
have no means of ascertaining by whom and in what year it was introduced into England. However, as it reached Germany in the second year of Queen Elizabeth's reign, it is probable that plants were soon afterwards sent to her gardener; as we find by the survey of the royal gardens of Nonsuch, in Surrey, which were planted in the time of Henry the Eighth, and were one of the favourite residences of Elizabeth, that in the privy-gardens of that palace there were fountains and basins of marble, one of which was " set round with six lilac trees, which bear no fruit, but only a very pleasant smell." This survey was made in the time of Charles the Second, who gave the palace and gardens of Nonsuch to one of his mistresses, who pulled it down and sold the materials.

Gerard considered the lilac to be a species of privet: later writers took it for a kind of jasmine; and M. Jussieu, in his Natural Classification of Plants, also makes it one of the jasmine family.

In the shrubbery the lilac is amongst thefirst that announce the return of spring; and no flowering tree makes known the welcome tidings in a more pleasing garb, for the beauty of its foliage, and particularly that of the white yariety, is scarcely less agreeable than its 
girandoles of flowers, that shed their perfume so delightfully over our May-day walks.

The praise which Eudosia bestowed on the swan, we may safely borrow for the white lilac, as it is equally an

"Emblem of modest grace,

Of unaffected dignity and ease,

Of pure and elegant simplicity."

Many persons complain of the lilac for shedding its flowers so early, without taking into consideration at what an acceptable period the blossoms appear, and that it lends its beauties, with those of the laburnum, to fill up the space between the flowering of the almond and the arrival of the rose, which leaves us nothing to regret.

The most beautiful variety of the common purple lilac is that known by the title of the Scotch lilac, from its having been first mentioned in the catalogue of the Edinburgh garden. The flowers of this kind are of a much richer colour than those of the blue lilac, the buds and under side of the petals being of a hue between purple and carmine, that gives a kind of ripeness to the appearance of the clusters, which are produced in larger. groups, and with larger flowers also, than any other lilac. This kind likewise gives out its blossoms about fourteen days later than the 
common lilac, which lengthens the season of these flowers very considerably. The Scotch lilac is succeeded by the Persian lilac, which continues in blossom until the end of June, thus decorating our plantations from eight to ten weeks with the most agreeable attire.

During the last year we enjoyed the forced lilacs from the beginning of February until those of the open garden appeared, which pleasure was lengthened by our meeting with them in full perfection at Paris in the months of August and September, where

\section{Le lilas qui pend, avec grace,}

Offre ses bouquets ingénus,

at a season we have not yet met with them in this country, although we have equal means with the French of retarding the time of their flowering.

The art of retarding the ripening of fruits, and the flowering of plants, is scarcely less desirable than that of forcing them. We have, therefore, dwelt on it at considerable length in the third edition of the Pomarium Britannicum, for by this means we join, as it were, the two ends of the year.

The common lilac grows to the height of eighteen or twenty feet, when planted in a rich light soil; therefore it should hold a

VOL. II. 
middle rank in the plantation. And we have already noticed how charmingly it contrasts with the laburnum and the Guelder rose; the purple variety being placed with the snow ball, and the white lilac advancing its pale leaves before the cypress, the bay tree, or other dark evergreens; whilst the blue Persian lilac may spread its more humble, but not less graceful branches, in the foreground of its white relative. The Persian lilac seldom exceeds five or six feet in height in the most favourable situations ; therefore it should only be placed in front of the shrubbery clumps or plantations. It often spreads to a considerable extent, and covers its whole mass with its loose branches of delicate flowers, which are of a more agreeable, though less powerful odour, than those of the common lilac. $\mathrm{NT}_{\mathrm{e}}$ have seen large bushes of the common privetleaved lilac growing on lawns, bending their slender branches to the turf every way, and forming a mount of blossoms, arising from the green sward, that could leave the most voluptuous florist nothing to wish. Of the Persian lilacs, the variety with cut or pinnatified leaves was the first introduced, which Parkinson tells us, in 1640, was then growing in the garden of Master Tradescant, at South Lambeth. It is noticed also by Parkinson, in his 
"Garden of Pleasant Flowers," of 1629, but he there states that it was a stranger to England, and that he described it from foreign accounts, with a hope that some one might be induced to bring it to this country. It is therefore clear that its first introduction was between these two dates. It was formerly. called the Persian jasmine by our nurserymen, although it was first introduced into Europe with the Persian name of Agem. It is generally supposed that the white Persian lilac is only an accidental variety, either raised from seed, or produced from suckers of the blue sort.

The Chinese lilac was first brought to this country in 1795. It is of a middle stature, between the Persian and the common lilac, and its leaves smaller than the common kind, with branches that are generally better furnished with blossoms, and that are both larger and deeper coloured than those of the Persian lilac.

The lilac should never have its branches shortened, as the flowers are always produced at the ends of the shoots of the former year, and just below the girandole of flowers other shoots conre out to succeed them, and contribute much to the beauty of the flower. The part on which the flower stands, decays down 
to the young shoots every winter. Thus nature prunes the lilac, but the trees of the common lilac are greatly improved, by attention in keeping the stem free from suckers, as it will always be observed, that those plants which are so trained, produce the finest and mosi abundant flowers, and on this account, the plants that are raised from seeds are much to be preferred, as they are not so apt to abound in suckers. If the seeds be sown as soon as ripe, they come up the following spring, and generally flower the third or fourth year from seed, which is earlier than those that are taken from suckers. As the Persian lilac seldom ripens its seed with us, it is usually propagated by suckers, but it is more desirable to multiply the tree by laying down the young branches, which in one year will be sufficiently rooted to transplant.

We cannot close our account of the lilac: without observing that it is amongst those trees that retain their verdure the longest; and as it cannot be too familiar with us, it is to be hoped that we shall see it creep into our hedge rows, and sometimes border our woodland scenes. 
LIME, OR LINDEN TREE.-TILIA.

Natural order, Columnifere. Tiliacea, Juss. A genus of the Polyandria Monogynia class.

Diff "And the lime at dewy eve Diffusing odours." Cowpen.

Fasmion reigns over the toilet not with more arbitrary power than she governs the plantation. She even enters the forest, declaring war against and levelling to the earth all such as are not in favour with her court; and as Caprice generally holds the situation of prime minister to this tyrannical goddess, it is not surprising that Folly should so often be employed as first marshal. Reason, who is deemed a traitor by this government, finds his opposition too weak to oppose such a phalanx, and sees the lofty tree and the lowly shrub alike rooted from our native woods, their antiquity and utility no more availing themselves, than their beanty or singularity influences the whimsical disposition of Fashion, who is thought to be a spurious daughter of Taste. In vain did the lime fill 
the sighing breezes with delightful odours,in vain were its agreeable shade and pretty umbels offered as a ransom to appease Fashion, offended by the litter of its early falling foliage; her influence was too great, and the lime bowed its noble head to the axe of Folly, leaving its thinly scattered offspring to the protection of Obscurity, until Reason return to resume his administration. Monsieur Louis Liger remarks, in 1703, that the lime, or linden-tree, was then gone out of fashion in the French plantations, being supplanted in favour by the hornbeam and the elm. But our celebrated nurserymen, London and Wise, tell us, in 1706, that it was then more in use in England than any other tree "for standards and espaliers, having found the inconvenience of planting elms near the fruit trees, or good plants; because the roots of the elm impoverish all the ground where they grow."

This tree is the $\Phi_{i}^{\prime} \lambda$ upa ( $p$ hilyra) of the Greek writers, and the Tilia of the Latin authors. It is thought that the Greeks named it Philyra, because the inner bark formed thin sheets on which they anciently wrote, instead of parchment or paper. The Latin name is supposed to be derived from rínov, which signifies a feather, because the flowers of this tree are produced from a kind of tongue, 
called the bractes, which very much resembles a feather. The Italians follow the Latin name Tilia, from which also the Spanish Teia, and the French Tilleul, seem derived.

The English title seems to be a corruption of the Dutch Linde or Lindenboom, or the German Linden or Lindenbaum, as all our early writers call it Line, or Linden-tree; and as we have now one species of the citrus-tree called Lime, it would be desirable to resume the ancient name of this tree, and call it Linden, to avoid confusing the two.

The linden is a native of Europe, and, according to Thunberg, of Japan also. Mr. Aiton makes it a native of this country; but it is hardly to be supposed that the able compiler of the Hortus Kewensis could possibly follow back the register of each individual plant with the scrutiny of a poursuivant at arms.

We find no English name for this tree but what is evidently borrowed from the Germans, and our earliest writers mention it as a rare tree. Dr. Turner tells us, in 1568, "it groweth very plenteously in Essekes, in a parke within two mile from Colichester, in the possession of one Master Bogges; it is also very common in high Germany." Gerard observes, in 1597, "that the female linE 4 
den-tree groweth in some woods in Northamptonshire; also neere Colchester, and in many places along the highway leading from London to Heningham in the county of Essex. The male linden-tree groweth in my Lord Treasurer's garden in the Strand, and in sundry other places, as at Barnelmes, and in a garden at Sainte Katharine's, neere London."

Parkinson says, in 1640, "the female linden-tree is planted in many places in our land, chiefly for the large sweet shadow it maketh; the others are very great strangers in this land, scarce to be seen any where."

Evelyn complains, and says, "it is a shameful negligence that we are not better provided of nurseries of a tree so choice and universally acceptable." He tells us, that " the young trees were then sent for from Flanders and Holland, to our great cost, although they were to be found in some of our woods."

Excepting the torrid zone there is no part of the globe whose timber-trees do not thrive in this country as well as in their native soil. The famous linden-tree of the duchy of Wirtemberg, which gave to the city of Neustatd the name of Neustatd-Ander grossen Linden (the City of the great Linden), although it was of 
prodigious height and nine feet in diameter, is not to be compared to one in this country, which grew at Depenam, in Norfolk, ten miles from Norwich, which measured near the ground forty-eight feet in circumference, or sixteen feet diameter; and at some distance higher it girthed thirty-six feet, and in the least part of the trunk it measured twenty-five and a half feet, and was to the uppermost branch, ninety feet in height. (The measurement of this tree was sent to Evelyn by Sir 'Thomas Brown of Norwich.)

Switzerland is celebrated by Evelyn for its enormous linden-trees, many of which remain sacred to this day. He particularises the famous linden at Zurich; as also one at Schalouse, under which was a bower composed of its branches, capable of containing 300 persons sitting at ease, and so thick was the foliage that the sun never penetrated.

There is a prodigious linden now standing in the village of Prelly, in the canton of Vaud in Switzerland, under whose shade the rural entertainments of these amiable and interesting people are held. Each village of this canton is governed by twelve men, who are chosen to maintain the observance of the laws; and it was beneath the extending branches of this celebrated tree that the mu- 
nicipality of Prelly formerly held their common council, seating themselves on the roots which have elevated themselves above the earth, as it were to form a natural bench for the justice of these simple people. This lindentree is visited by all who make the tour of Switzerland, and many a traveller exclaims with Langhorne:

"O let me still with simple nature live,

My lowly field flowers on her altar lay, Enjoy the blessings that she meant to give, And calmly waste my inoffensive day!"

We have already noticed that the linden was one of the papyraceous trees of the ancients. Munting affirms he saw a book made of the inner bark of this tree, which had been written about a thousand years; and there is a similar one in the library at Vienna, which contains a work of Cicero, De Ordinanda Republica, et de inveniendis Orationum exordiis. It was formerly amongst the varieties of Cardinal Mazarine, and which the Count of St. Amant, then governor of Arras, 1662, procured for the Emperor at the price of eight thousand ducats, which, if silver ducats, would amount to $1800 l$., and if gold, $3800 \%$.

Pliny tells us, that in ancient times fillets or ribands for chaplets were also made of 
the inner bark of the linden, and which it was esteemed a great honour to wear. The Romans also made cords and ropes from the thready substance which is found between the wood and the inner bark of this tree. The Roman cooks sliced the inner bark of the linden to boil with meats that were over salted, as it was found to make them perfectly fresh.

Of the ancient use of the timber of this tree, we learn from Virgil, who says :

"Of beech the plough-tail, and the bending yoke, Or softer linden, harden'd in the smoke."

Gcor. :

It is from the wood of the linden-tree principally, that the incomparable carvings of Gibbons were formed, which for lightness and elegance of design have never been equalled in modern times, and perhaps not surpassed by the chisels of the ancients, as those beautiful festoons of fruits and flowers in His Majesty's castle at Windsor, and those which ornament one of the noble apartments of the Earl of Egremont's mansion at Petworth, will evince, as well as those which decorate the choir of St. Paul's and other churches, and noble residences both in London and in the country.

Architects make their models of this wood, 
and the carvers prefer it on account of its delicate colour, close grain, easy working, and for its not being liable to split. That it is not subject to worms must be satisfactorily proved by the preservation in which we now see the works of Gibbons, that have been exposed since the time of Charles the Second. It is also remarked by Pliny, that the worm never injured this timber. Evelyn tells us, that this wood is preferable to the willow, being stronger yet lighter. We presume that it was from the strong recommendation of this tree in the Sylva, that it came so much into use in the latter time of that author, as about that time it was planted in St. James's Park; and we find it was also frequently planted in country towns, and trimmed up to screen the windows from the sun; for which purpose it was well adapted, both on account of the fragrance of its flowers and its shade, which is not required after the time the linden throws off its leaves; and few trees were found to bear clipping better than this, as it soon heals the wounds that are caused by the knife; and the branches are so tough that they seldom suffer by the wind, and were found to bear so great a weight that platforms were laid on them, and arbours made in the tree one over the other.' Dr. Turner 
says he had seen one in Germany witl a table on it, around which ten men could sit. Parkinson also notices one which he liad seen at Cobham in Kent, that formed three arbours over each other, "which was a goodly spectacle."

The leaves of this tree begin to open about the middle of April, and are generally fully expanded by the 20th of that month. The flowers begin to open by the middle of May, but are not in their full beauty before the middle of July. They are in some degree similar to those of hawthorn, but 'neither so' white nor quite so large, and the flower-stalk is attached to a whitish tongue-shaped leaf. Their fragrance is agreeable to most people, and very attractive to the industrious swarm, for

Sits on the bloom, extracting liquid sweet
Deliciously."

But it is observed that no animal will eat the fruit or seed of the linden-tree; Columella recommends the leaves as a good fodder for cattle.

A coarse cloth was formerly made of the inner thready bark, but it was more generally used for cordage, because it has the property. 
of remaining in the water without rotting. The Greeks made bottles of the middle bark. of the linden, which were lined, with pitch to prevent leakage.

It is said that no wood chars better than this for the purpose of gunpowder. It is also turned into bowls and dishes, and little pillboxes were made of it before those of paper were invented.

The flowers were formerly held in esteem by the apothecaries, being accounted cephalic and nervine, and good for the apoplexy, epilepsy, and palpitation of the heart, \&c. They were sometimes added to the spirits of lavender, and they formed the aqua florum tilice of the last age. The berries, reduced to powder, were used in dysenteries, and the bleeding at the nose. Hoffman speaks in high terms of the infusion of the flowers in water after the manner of tea, by which he says he has known an inveterate epilepsy perfectly cured.

Notwithstanding the rules of fashion, we shall always be glad to meet the linden-tree in our summer walks or rides, whether it spring from the hedge-row, the enclosed park, the open street, or form the boundary of the shrubbery, where we hope the sight of it will 
remind the young orator of the eloquence of him whose works, we have already noticed, are preserved on its bark.

In humbler situations we would have this tree give the artist emulation to excel the hitherto unsurpassed Gibbons.

So great was the honour thought of planting a linden-tree on the continent, during the confederacy, that as soon as one party had made themselves masters of a village, they planted a linden in the public place, destroying those which their adversaries had set, and which was again hewed and another planted as often as victory decided in favour of a fresh party.

The finest linden-trees are those that are raised from seed, which should be sown in the autumn, as soon as they are ripe, and covered with mould about three quarters of an inch deep. They are also propagated by layers, which in one year will make a good root: these should be laid down and transplanted about Michaelmas. The linden is also increased by cuttings; but the tree seldom forms so fine a cone-like shape when propagated by either of the latter methods, as when raised from seed. 


\section{MAGNOLIA. - MAGNOLIA.}

Natural order, Coadunatc. Magnolia, Juss. $A$ genus of the Polyandria Polygynia class.

"Columbus shew'd

The western world to man."

IF we except the general deluge and the origin of Christianity, the discovery of America may be considered the most important event that has been recorded since the creation of the world. It has discovered to us an immense territory of land; a people whose habits and minds were new to us; it exhibited unknown animals, and afforded us vegetables no less novel than numerous. It has had the effect of a new creation; new wants have arisen, and new inventions have sprung up to gratify them.

“ Then commerce brought into the public walk The busy merchant; the big warehouse built;

Raised the strong crane; choak'd up the loaded street With foreign plenty; and thy stream, O Thames!

Large, gentle, deep, majestic, king of floods !

Chose for his grand resort."

Thomson 
The shrubs of the new world have been transplanted into our gardens, and the forest trees of America rear their heads in our woods; whilst, in return, we hav eplanted colonies on the newly-discovered shores, who have reared their national constitution and laws with such care, that it may probably be found thriving there in its purity when time and corruption shall have destroyed the parent trunk.

The magnolia grandiflora, or laurel-leaved magnolia, is a native of that part of America which has been named Florida, from the beautiful plants with which it abounds; and when growing in its native soil, the magnolia is esteemed the most beautiful tree known; it reaches from 90 to 100 feet in height, and is clothed with an evergreen leaf of the most lucid colour on the upper surface, and of a russet tint beneath. The shape is nearly that of the common laurel leaf, but much larger; and being agreeably waved on the edge, it has not the heavy and stiff appearance of the laurel leaf, although the consistency is the same. It is sessile, and placed without order on every side of the branches. The flowers appear from June to September, during which time they perfume the air for a considerable distance round with the most agreeable odour, which at one moment reminds us of 
the jasmine or lily of the valley, and the next, of the violet mixed with the apricot.

During the last summer we saw a fine tree of this description in the exotic gardens of M. Bourseau, Rue Mont Blanc, in Paris, which scented the whole of that elegant plantation.

We have also seen a most noble magnolia in the grounds of the Priory, near Ryde, in the Isle of Wight; and which, we were then told, often wafted its delightful fragrance to more than half a mile in distance. The flowers are produced at the ends of the branches, and are so large as to measure from seven to eight inches in diameter, and are composed of eight or ten petals, narrow at their base, but broad, rounded, and a little waved. They spread open like a tulip, and have the appearance of white kid leather more than of a vegetable substance. In its native country this tree begins to flower in May, and gives out a succession during the whole summer, so that the woods are constantly perfumed with its odour. The pencil can give but a faint idea of the splendour of this beautiful tree, which defies the pen altogether to describe its charms; its leaves are more glossy than those of the laurel, and from nine to ten inches in length, and about three inches in breadth, with a softness on the underside, that gives great variety to the foliage. 
The young branclies are of a fine purplish brown, and when each spray, for a hundred feet in height, is holding up its petaled vase, as if to offer incense to the sun that nourishes its fruit, a mass of beauty is composed, that rivals the proudest work of man.

The fruit of the magnolia is seated in the flower in a manner similar to the strawberry, which afterwards becomes a strobile or cone, composed of many capsules, each of which, when perfect, contains two scarlet seeds. We are not aware that the fruit has ever matured its seed in this country, though we have seen some old plants that have formed strobiles of considerable size.

This splendid plant received the title of magnolia from Plumier, who so named it in honour of Pierre Magnol, prefect of the botanic garden at Montpelier, and author of several works on plants.

Sir John Colliton is thought to have reared the first plant of this kind in England, at Exmouth, in Devonshire, some time prior to 1737. It was unknown to Mr. Miller, in 1724, when he published the first edition of his Gardener's and Florist's Dictionary ; but in a later edition, he mentions that there were a great many plants in England before the year 1739, but the severe winter of that year destroyed most of the young ones. He also 
tells us, that he had a pretty large plant which was apparently killed by the severe winter of 1739-40, but that he cut it down after Midsummer, and that it shot up again the year following. We notice this circumstance more particularly, because in case of similar accidents, gardeners may not be too hasty in grubbing up the roots. The magnolia is generally injured most by the early frost, as the extremities of the young shoots are then tender.

His Grace the Duke of Richmond has two of the finest standard magnolia grandiflora trees in this country, at his seat at Goodwood in Sussex, one of which at six inches from the ground, girths three feet one inch, and at four feet from the ground, two feet five inches; at about five feet from the earth it divides into branches, forming a very beautiful head about twenty-three feet in height. The other is thirty-five feet in height, and measures four feet in circumference at fourteen inches from the ground: these trees flower abundantly every year. The time of their having been planted cannot be now correctly ascertained.

The magnolia should occupy a situation sheltered from the north and north-east winds, but fully exposed to the south or south-west sun. It seems tothrive in the sea air, when the situation is not exposed; and the soil congenial to this tree is a deep rich loam, rather dry than moist. 
From the great rarity and extreme beanty of this tree, we think it deserving of more care than is generally bestowed on it, so as to secure it from the frost, and which might easily be done by placing blocks of wood in the earth, with mortices in them, into which poles might be fixed, and a frame or wirework thrown over, to lay mats or other covering on during the inclement nights. Tall evergreens, of the darkest foliage, form the most proper back ground for this tree.

Our nurserymen raise these trees from seeds, which are sown in pots, and plunged into old hotbeds of tanners' bark. 'They are seldom strong enough to be planted in the open ground under six years; therefore gardeners are justly entitled to a considerable price for a plant that has required so much of their attention in its propagation. The magnolia may also beraised from layers and cuttings; but these seldom make handsome standard trees.

We have now eighteen species of this plant, nine of which are natives of North America, and nine belong to India, China, or Japan; and should we be able to naturalize them so as to endure our winters in the open air, as the common tulip tree has been made to do, they cannot fail of being regarded as one of the greatest ornaments of the shrubbery.

The swamp magnolia, glauca, was the speF 3 
cies of this plant first cultivated in England, as it is mentioned by Ray, in 1688, as being amongst the rare exotic trees and shrubs then growing in the episcopal garden at Fulham, where it was sent by Banister to Bishop Comptom. This shrub seldom exceeds sixteen feet in height in its native soil; it is found in low, moist, or swampy ground in North America, but not more northerly than Pennsylvania. The perfume of this plant resembles that of the lily of the valley, with a mixture of aromatic odour; and its fragrance is so great, that the trees may be discovered at the distance of three quarters of a mile by the scent of the blossoms, particularly towards the close of day, when it is, we are told, beyond description pleasant to travel in the woods at the season of their flowering. The tree is known in America by the name of White Laurel, Swamp Sassafras; but it is more generally called the Beaver-tree, because the root is eaten as the most favourite food of the beaver, and it is therefore employed to catch these animals. The flowers of this species of magnolia are similar to those of the grandiflora. They consist of eight petals, but are not more than three or four inches over. The bark of the swamp magnolia, as well as the fruit and the young wood, form one of the American domestic medicines. 


\section{MAPLE TREE.-ACER.}

Natural order, Trihilatce. Acera, Juss. A genus of the Polygamia Monocia class.

"Nor less attractive is the woodland scene, Diversified with trees of every growth."

I $\mathrm{T}$ is in our hedgerows principally that we find the common maple, as it is seldom, if ever, allowed the honour of adding its shade amongst the number of those that compose the British shrubbery; although, according to Chaucer, it formed the bower of the fair Rosamond de Clifford; and Virgil celebrates it as the throne of Evander, and its branches as the canopy under which he received and seated Eneas.

"On sods of turf he sat, the soldiers round;

A maple throne, rais'd higher from the ground, Receiv'd the Trojan chief; and o'er the bed A lion's shaggy hide, for ornament, they spread."

ÆNEIS, 8.

Pliny enumerates ten different kinds of the maple that were known to the Romans in his time, the timber of some of which was in the highest estimation on account of its fine grain and beautiful veins. It was considered

$$
\text { F } 4
$$


next to the citron wood in value; and we are told that in some instances, when it was finely spotted, it brought its weight in gold. To such a height did the fondness of the Romans for curious wood carry them at one period of their history, that their tables were more expensive than the jewels of their ladies.

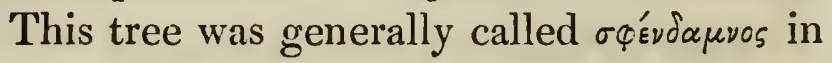
Greece, although they distinguished different kinds of maple by different appellations, which was also the custom of the Romans; but it is most commonly named acer in Latin, from acer, acris, on account of the hardness of the wood, or from acre ingenium, from its being so much in use by the most ingenious artificers in fine works. Evelyn tells us, that the wood of the maple is far superior to that of beech for all kinds of turnery ware; and that in his time it was turned into cups and bowls, and worked so thin as to be almost transparent; and it was also greatly esteemed for its lightness, and sold under the name aier. It was likewise in considerable demand for making various musical instruments. The author of the Sylva states, that by shredding up the boughs to a head, he caused the maple to shoot to a wonderful height in a little time; at present it is seldom suffered to arrive to the size of a 
tree, being generally kept as underwood, and this has in all probability arisen from its character of being noxious to the subnascent plants of other kinds, by the clammy dew which it sheds upon them. It is, however, of quick growth, and affords good fuel, and when allowed to grow into timber, it makes excellent gunstocks, screws for cyder presses, and other purposes that require hard wood. In the vale of Gloucester and other places where oak timber is scarce, it is used for making gates and for other purposes of husbandry.

The largest maple tree in England, is in the church-yard of Boldre, in Hampshire, under whose branches the Rev. William Gilpin, author of "Remarks on Forest Scenery," \&c. lies buried.

The common maple, accr campestre, flowers in the beginning of April, and the leaves appear about fourteen days later. It is raised by seed, but very seldom cultivated at present, though there are thirteen distinct species of maple, besides several varieties. The sugar maple, acer saccharinum, is of great importance to the inhabitants of North America, as its saccharine sap affords them sugar, and little if at all inferior to what is obtained from the cane in the West India islands. Our 
account of this tree will be found under the article Sugar, in the history of cultivated vegetables.

The scarlet flowering maple, acer rubrum, is cultivated as an ornament for the shrubbery, where it flowers in April. It is a native of North America, and is found abundantly in the swamps of Pennsylvania, where the bark is used to dye a dark blue colour, and also for an ingredient in making ink.

The Canadians tap this tree, from the juice of which they make both sugar and treacle, as well as from the sugar maple. Mr. John Tradescant cultivated the scarlet flowering maple in this country as long back as 1656. 


\section{MEZEREON. - MEZEREUM.}

\section{A SPECIES OF DAPHNE.}

Natural order, Vepreculce. Thymelae, Juss. $A$ genus of the Octandria Monogynia class.

"See Nature hastes her earliest wreath to bring With all the incense of the breathing spring."

Pope.

" Mezereon too,

Though leafless, well attired, and thick beset With blushing wreaths, investing every spray."

CowPER.

This pretty shrub, which decks its branches with garnet-coloured petals so amply as to hide its dead-looking wood, and often so early that its murrey flowers shine above a bed of snow, has been made in floral language to express a desire to please, whilst others make it the emblem of coquetry, comparing it to a nymph, who in the midst of winter seeks admiration in her summer robes.

As our admiration is demanded in the saloon by the well-dressed coquette, so is our notice attracted in the shrubbery by this 
early-flowering plant, whose perfume, like the arts of coquetry, is both delightful and dangerous.

The mezereon sometimes blossoms as early as the end of January or beginning of February, and when three or four of them are planted in a group, the effect is very agreeable, as the whole shrub becomes a mass of flowers without confusing the branches, the top of each of which terminates with a tuft of leaves like the crown of a pine apple, but of a beautiful yellow green, which harmonises as agreeably with the garnet set spray, as the grey green contrasts with the golden fruit of the ananas. It is no small recommendation to the mezereon, that it holds its flowers for a considerable length of time, and seldom fades until eclipsed by the arrival of the more delicate petals of the almond, that also blooms on a leafless bough.

The fruit of the mezereon is a berry of a fine red colour, that is exceedingly ornamental in June and July, but whose qualities are of a more deadly poison than the arts of the coquette, whose injuries seldom prove mortal.

The whole of the mezeron is extremely acrid, particularly when fiesh, and if retained in the mouth excites great heat and inflam- 
mation, particularly of the throat and fauces. The branches should therefore never be suffered to be cut for nosegays, as young people may be injured by putting the sprigs into their mouths. Children should be especially cautioned against gathering the berries. Mr. Bradley tells us that he ate some of this fruit, which were not unpleasant in taste, but that in about an hour after he had swallowed them, he found an extraordinary heat in his throat, which caused a violent burning pain for about twelve hours.

Nature, whose works never cease to excite our admiration, astonishes us by the wonders contained in the buds of this plant, where not only the flowers, but the parts of fructification may be distinctly seen the year before they unfold themselves. How infinitely do these secret labours surpass the most finished performance of the ablest human artist, yet how few regard them in comparison to the number that run after the works of man!

Modern botanical works claim the mezereon as a native of our soil, but we are decidedly of opinion that their claim is founded on error. It does not appear to have been known to our earliest writers on plants, and is not mentioned by Turner, in 1568; and Gerard tells us, in his roluminous work of 
1597 , that " this plant groweth naturally in the moyst and shadowie woods of most of the East countries, especially about Elbing, which we call Meluin, in Polande; from whence I have had great plentie thereof for my garden, where they flower, flourish, and bring their fruit to maturitie." This author calls it " Spurge Flaxe, or Dwarffe Bay," which he says " the Dutchmen call Mezereon, and the English, Dutch Mezereon ; but we," he adds, " had rather call it Chamelaa Germanica." Parkinson gives it this latter name with the addition of that of mezereon, in his work on plants, entitled " the Garden of Pleasant Flowers," which was published in 1629 ; and in his larger work of 1640 , he retains the same name, calling it also Flowering Spurge; and he says "it grows naturally in Germanie;" but that the Spurge laurel grows wild in England. It was never discovered by the indefatigable Ray, or his immediate successors in this country.

Miller was the first author who mentions the mezereon as a native of this country; and which was not until about 240 years after it had been introduced by Gerard. Miller considered it indigenous to our soil, because it had been found growing near Andover, in Hampshire. It has since been found by $\mathrm{Mr}$. 
White, in Selborne-lianger, in the same county ; by Mr. Woodward, at Laxfield in Suffolk; and it has also been seen in the beech woods of Buckinghamshire. But these late discoveries by no means prove it a native of the soil, as it is well known how anxiously the thrush and blackbird hunt the garden for the berries of this shrub, the seeds of which are thus conveyed into the copse or wood; where when one plant has sprung up, others would soon succeed, as we have always observed numerous young plants springing up beneath this shrub in the plantation.

We now reckon eleven different species of the daphne, one of which daphne laureola, spurge laurel, is a native of our woods, and although a plant whose flowers make but little show, its fine evergreen leaves recommend it to the planter, and more particularly as it thrives under the shade of trees or taller shrubs, where but few other plants will exist.

There is a variety of the mezereon with white blossoms, and yellow berries, and another with variegated leaves. They are all raised by seed, sown as soon as ripe in August. The bed or border should be exposed to an eastern aspect; and the plant thrives best in a light sandy earth that is dry, for in 
cold wet land it becomes mossy, and neither makes much progress, nor produces many flowers.

The mezereon seldom exceeds from three to four feet in height, and therefore it should be placed in the foreground of taller shrubs, for when set in the middle of the plantation it is sooner obscured by faster and taller growing shrubs.

The Neapolitan mezereon, Daphne Collina, is an evergreen that covers the hills and fields on the banks of the Vulturnus, in Italy, as the furze does our commons in England, and it is now found to endure the winters of our climate nearly as well as the common mezereon. It was first cultivated in this country in 1752 ; but as an ornament to the shrubbery we prefer the deciduous kind, as the flowers of the Neapolitan mezereon are partly obscured by the leaves.

This genus of plants is supposed to be the $\Delta \alpha \varphi \nu \eta$ of Theophrastus and Dioscorides; but as there is some doubt of this from the brief remarks they have made on the plant under that name, we shall confine ourselves to the discoveries which modern physicians have made of the virtues of the mezereon, the most important of which was found out by Dr. Russel, whilst physician to St. Thomas's 
Hospital; but as it only concerns the sons of Esculapius and the disciples of Venus, we shall refer them to the London Med. Obs. vol. iii. p. 189.

The considerable and long-continued heat and irritation that is produced in the throat, when mezereon is chewed, induced Dr. Withering to give it in a case of difficulty of swallowing, seemingly occasioned by a paralytic affection. The patient was directed to chew a slice of the root as often as she could bear it, and in about a month she recovered her power of swallowing; she had suffered the above complaint upwards of three years, and was greatly reduced, being totally unable to swallow solids, and liquids but very imperfectly. *

The medical men of France have a practice of applying the bark of this plant to the skin, for the purpose of producing a discharge or issue without blistering; and it is thus rendered useful in chronic cases of a local nature, answering the purpose of what is termed a perpetual blister, whilst it occasions less pain and inconvenience. The operation is performed, by affixing to the skin a piece of the bark about an inch square, that has been pre-

\section{* Woodville.}

VOL. II. 
viously soaked in vinegar; an ivy or plantain leaf is then bound over it, and this is renewed night and morning until a discharge is established, then once a day is sufficient.

Gerard notices the medicinal qualities of this plant, and tells us in his usual quaint manner, that " if a drunkard do eate one graine or berric of it, he cannot be allured to drinke any drinke at that time, such will be the heate of his mouth and choaking in the throte." 
MOUN'TAIN SERVICE. - MOUNTAIN ASH, on QUICKEN TREE. - SORBUS AUCUPARIA.

Natural order, Pomacer. Rosacea, Juss. A genus of the Icosandria Trigynia class.

"Where shrubs and fruits their mingled sweets exhale, Or flowers, or trees, whose branches proudly bend, Their different bloom, their different race extend; Through them what interest do your fields present ! Observe their varied colours, form, and bent."

Delille.

This elegant tree seems designed by nature as an ornament to our mountainous plantations of fir and pine, whose dark and fixed foliage contrast so decidedly with the light green tint of these long pinnated leaves, which are seen to move with additional grace when placed in the foreground of sombre trees. It is in this natural situation that the large corymbs or umbelliferous clusters of white flowers are so conspicuously beautiful in the month of May, when each branch is terminated by these bouquets of pearly blossoms. But it is in the months of August and

$$
\text { G } 2
$$


September, that the mountain ash adds so much to the gaiety of picturesque scenery, when the glowing vermilion fruit decorates the boughs so superbly by its pendent pomes, for botanical language will not allow us to say berries, because the seeds of this plant are disposed like that of the apple in a fleshy pulp, and divided into cells.

Ancient poets tell us, that the Amazons formed their spears of this wood, by which they boldly defended themselves against mortals, whilst the Cambro and the North Britains, in later times, depended on the powers of this wood to protect them from supernatural enemies; and there are still some persons, who cling so obstinately to superstition, as to believe that any small piece of this tree carried about them, will prove a sovereign charm against all the effects of enchantment or witchcraft.

In Wales, says Mr. Evelyn, "this tree is reputed so sacred, that, as there is not a church-yard without one of them planted in it, (as amongst us the yew), so on a certain day in the year, every body religiously wears a cross made of the wood, and it is reputed to be-a preservative against fascinations and evil spirits, whence perhaps we call it witchen, the boughs being stuck about the house, or 
the wood used for walking staves." It seems to have been one of the sacred Druidical trees, as stumps of it were frequently found near the circle of their temples; and Mr. Lightfoot remarks, that this tree may to this day be observed to grow more frequently than any in the neighbourhood of the Druidical circles of stones, so often seen in North Britain.

It is curious to observe for what opposite purposes plants are used in different countries. The mountain-ash, which our northern friends so religiously planted to keep off enchantment and sorceries, is most carefully propagated by our more southern neighbours, as one of the principal charms by which they entice the belles of Paris into the public gardens, where they are at liberty to use all the spells and witcheries which they are mistresses of; and it must be confessed that no tree has a more enchanting appearance when lighted up with lamps than the mountain-ash, by its brilliant scarlet fruit, in the months of August and September.

At Strathspey, in Scotland, it is the practice of the country people to make a hoop with the wood of this tree, through which they oblige all the sheep and lambs to pass both in the morning and evening of the first

$$
\text { (c) } 3
$$


of May; and the Scotch dairy-maid will drive her cattle to the shealings or summer. pastures, with no other rod than that of the roan-tree, by which name it is generally known in Scotland. It obtained the name of mountain-ash, in England, from its growing in hilly situations, and its leaves being pinnated like those of the common ash, fraxinus; but it has no more affinity to the ash, than the apple-tree has to the oak.

The trivial name of aucuparia was given it from the practice of the fowlers, who use the fruit to bait their springes with, by which they entice the redwings and fieldfares to their snare. The Scottish highlanders, as well as the inhabitants of Kamtschatka, distil an ardent spirit from this fruit; and in Wales the poor people infuse it in water, and make an acid liquor resembling cider, which they drink with pleasure.

In the island of Jura they use the juice of this fruit as an acid for punch.

The wood of this tree is tough and closegrained, but not hard; and it appears to have been much more plentiful in our woods formerly, than at present; as Evelyn says, it is mentioned in a statute of Henry the Eighth, and he observes, that the fletchers, commend 
it for bows next to yew, and that the wheelwrights praise it for being all heart.

It is a native of cold mountains, and grows naturally on Mount Libanus, and also in Siberia, as well as in Wales, Ireland, Scotland, and the northern parts of England, where it becomes a considerable-sized timber-tree.

This highly ornamental tree is raised from seed, and it will grow upon almost any soil, either strong or light, moist or dry. Its situation in the pleasure ground should be between the tallest flowcring shrubs and the forest trees. We have already noticed the colour and time of its flowering as a guide to what neighbour the planter should give it; but it is in the latter part of the summer that it makes the greatest figure, when loaded with its showy bunches of fruit, that have a delightful effect in the shrubbery, when there are but few shrubs in flower, and just before the trees change their summer tints for their autumnal hues.

The fruit of the mountain service is so tempting to the thrush and blackbird, that it is sure to attract these sweet warblers to the grove where it grows.

"Sanguineisque inculta rubent aviaria baccis." VIRGIL. 


\section{MYRTLE. - MYRTUS.}

Natural order, Hesperidec. Myrti, Juss. $A$ genus of the Icosandria Monogynia class.

" " and the fragrant branch Of glossy myrtle." Mrs. M. Robinson.

"Now let us range both far and wide, 'Thro' all the garden's boasted pride, There rising myrtles form a shade, There roses blush, and scent the glade." Cotron.

THIs beautiful plant, which attracts our attention by its irresistible charms, was made the emblem of Love, and dedicated to Beauty, when Venus first sprang from the froth of the sea. Mythological writers tell us, that when this fair goddess first appeared on the bosom of the waves, the Hours preceded her with a scarf of a thousand colours, and a garland of myrtle.

"Her waving locks immortal odours shed, And breath'd ambrosial scents around her head. To the soft Cyprian shores the goddess moves, To visit Paphos and her blooming groves; Where to her pow'r a hundred altars rise, And breathing odours scent the bahny skies. 
Conceal'd, she bathes in consecrated bow'rs, 'The Graces unguents shed, ambrosial show'rs, Unguents which charm the gods: she, last, assumes Her splendid robes; and all the goddess blooms."

Pope's Homer, and PitT's Virgil.

From the delightful perfume of the myrtle, the delicacy of its blossoms, and the glossy green of its perpetual foliage, it seems destined to ornament the forehead of beauty, and the temple of Venus, who was crowned with myrtle by the loves, after her victory over Juno and Pallas. It was with the branches of this tree that the mother of Cupid revenged herself on the audacious Psyche, who had dared to compare her transitory charms to an immortal beauty. It is also related, that Venus being surprised by a troop of satyrs as she was coming out of the bath, took refuge behind a myrtle-bush, which increased her attachment to this tree.

We learn from mythological fables, that crowns of myrtle were anciently called $\mathrm{Nau}$ cratites, from the following miraculous story which is related of Herostratus, a Naucratian merchant, who was overtaken by a terrible tempest at sea, that threatened to destroy his ship and all the mariners, until they implored the assistance of a little statue of Venus which he had brought into the vessel. Their supplications being attended to by the goddess, 
she caused a great number of myrtles to rise in and around the ship, with which the sailors formed crowns; and on their safe arrival at Naucrates, Herostratus presented the statue and the myrtles to the temple that was consecrated to Venus; on which occasion he gave a feast, where he distributed the crowns of myrtle to the guests, whence they were called Naucratites.

Pliny tells us that the Romans and the Sabines, when they were reconciled, laid down their arms by a myrtle-tree, where they purified themselves with the fragrant boughs of this sacred tree; and that to make atonement, and to ratify their marriage with the Sabine women, the former people built a temple on the spot, in which-was placed an image of the goddess, and which was dedicated to Venus Cloacina, from cluere, that is, to cleanse. The same author informs us, that myrtles were amongst the first trees that the people planted in the public places of Rome, to presage future events; and that there were two sacred myrtles growing before the temple of Quirinus, one of the oldest edifices in Rome, and erected in honour of Romulus. One of these myrtles was called Patritia, the myrtle of the nobility, and the other Plebeia, the myrtle of the commonalty; and as either of these trees 
flourished or decayed, so the success of these opposite parties was prognosticated. The temple of Quirinus was repaired under the consul Lucius Papirus Cursor, in the year 306 before Christ, when the first sun-dial that had been seen at Rome was set up.

There was also in Rome an ancient chapel and altar consecrated to Venus Myrtea, by which name the goddess was often worshipped.

Pausanias relates, that at Lemnos there was a statue of Venus, formed of myrtle, which Pelops caused to be made to insure his marriage with Hippodamia.

The myrtle-wreath was worn by those generals who obtained victories without bloodshed. Posthumius Tubertus, when consul of Rome, was the first who was honoured with this crown when he entered the capital in ovation, after having conquered the Sabines without shedding blood. These chaplets were dedicated to Venus Victrix. Papyrius Masso, who triumphed over the Corsicans, was allowed for ever after to wear this crown when he visited the Circensian games.

The weapons of war were also formed of this tree, as Virgil writes,

"The war from stubborn myrtle shafts receives;" and we learn from the same poet that it formed the arms of Camilla, a Volscian queen. 
"She shakes her nyyrtle javelin; and behind, Her Lycian quiver dances in the wind."

ANein, vii.

The ancients made great use of this plant in medicine, and they formed a kind of wine from the berries, as well as an oil which they extracted from the ripe fiuit of the myrtle. The Romans flavoured their wine with the berries, as well as many of their dishes in cookery, before the use of pepper was known to them, and even then it was in high estimation for making sauce for the brawn of the wild boar.

The myrtle is a native of Asia, Africa, and the southern parts of Europe. It grows common in Italy as an underwood; yet Pliny considered it as not being a native of that country, or of any part of Europe. He tells us, that the first myrtle which was seen in Europe was near Circeii, where the tomb of Elpenor, one of Ulysses' companions, stood ; and he remarks, that in his time it retained the Greek name, from which he also considered it a stranger. It is indeed the Greek name of this tree, Mupros, which has been followed by all the European languages. In Latin, it was called Myrtus; in German, Myrte ; in Dutch, Myrtus; in Danish, Myrter; in Swedish, Myrten; in French, Mirte; in Italian and Spanish, Mirto; in Portugueze, Myrta, or Murta. The Arabians call it Aes, Alas, and As. 
Fable informs us, that the Greeks named this tree Mupros, from Myrsine, an Athenian damsel, who, being overcome in wrestling and the race by Pallas, died of envy; but being a favourite of Minerva, she was metamorphosed into a myrtle-tree, which the goddess held next in esteem to her sacred olive : but Pæna says, it was so named from the fragrance of the berries and plant, nearly resembling the celebrated odour of Myrrha, myrrh. This beautiful evergreen has been made sacred to Veritas, as well as to Venus and Minerva.

"Unfading branch of verdant hue,

In modest sweetness drest, Shake off thy pearly tears of dew,

And decorate my breast.

" Dear emblem of the feeling mind,

Truth's consecrated tree!

Still shall thy trembling blossoms find

A faithful friend in me."

Mrs. Mary Robinson;

Cato wrote on three kinds of myrtle only, but Pliny mentions eleven varieties that were known in his time, and says that the most odoriferous myrtles grew in Egypt. It has been observed that this tree grows naturally only in hot sandy situations, from which it seems to remove all other plants, as if it would reign alone in the ground it occupied, thus imitating the goddess of which it is symbolical, who, when once she has taken possession 
of the heart, leaves no place for other sentiments.

"The spiry myrtle with unwith'ring leaf Shines here and flourishes."

Cowper.

It was upon a memorable occasion, that the myrtle was introduced into this countiy, as it is said to have been brought from Spain by Sir Walter Raleigh and Sir Francis Carew in 1585, when they resided in Spain, and discovered the preparations for the Spanish armada against us.

Sir Walter, we may presume, would lay this emblem of love at the feet of his royal mistress, who seems to have had no objection to such acts of gallantry; whilst Sir Francis, we may conjecture, took no less pleasure in planting Venus's favourite tree at Beddington in Surrey, where he had about the same time planted the first orange-tree that graced the British soil.

'This account of the period when the myrtle was introduced, seems confirmed by the writings of the prior and succeeding authors, for in Dr. 'Turner's history of plants, which was published in 1568, no mention whatever is made of the myrtle; but in 1597, Gerard speaks of it as a plant of late introduction, as he remarks that myrtles bear no fruit in England. 
Spenser, a poet high in the esteem of Queen Elizabeth and Sir Walter Raleigh, thus notices the myrtle in his " Faerie Queene."

"Beside the same a dainty place there lay, Planted with mirtle trees and laurells greene, In which the birds sang many a lovely lay."

Miller tells us in his first edition of the Gardener's and Florist's Dictionary,printed in 1724, that " at Sir Nicholas Carew's, at Beddington, is a myrtle of the Spanish broadleaved kind, which is above eighteen feet high, and spreads above forty-five feet." If this were the original tree, it would then be 156 years old, and most probably perished with the original orange-trees, that were killed by the severe winters of 1739-40, being then about 160 years old.

Evelyn says in 1678, "I know of a myrtle near eighty years old, which has been continually exposed, unless it be, that in some exceeding sharp seasons a little dry straw has been thrown upon it." It is most probable that he alludes to the tree at Beddington, as he frequently mentions in his diary having been there.

Parkinson informs us that he had three varieties of myrtle growing in his garden in 1629, which were the broad-leaver, and two varieties of the box-leaved. 
The myrtle is not so tender a plant as is generally supposed, and there are not many gardens but what afford some situation where this elegant evergreen will grow, particularly if it be slightly covered from the frost in the winter; and it is much less likely to be killed by the cold when planted in the ground, than when plantedin pots or tubs. Unfortunately, this plant is just too tender to endure exposed situations in the interior of this country, without some shelter or protection, but its beauty entitles it to a greater portion of our care, than it receives at present. It might even be preserved on the lawn by placing a light iron cage over it in the winter, that might be covered with moss or pannels of some ornamental design. It has always been observed that the myrtle thrives best in the sea air, on which account some suppose it to have been dedicated to Venus; and it is found just hardy enough to prosper in the southern and western coasts of England without cover. We have noticed very fine trees of the broadleaved or Roman myrtle, growing in Devonshire, and in the Isle of Wight, where it stands detached from any buildings, and is so common, that we have observed it in cottage gardens covered with linen hung out to dry. It 
grows freely in the neighbourhood of Worthing, and does not seem particular as to aspect, as we have observed trees of considerable height covering the east front of a cottage at Lancing, as well as the rectory house at Broadwater. In Worthing we have frequently known it ripen its fruit, and perfect its seed, in a western as well as in a south aspect. These trees are all of the common broadleaved variety, which is often called the flowering myrtle, because it blossoms more freely in this country than some other varieties. But we have seen a fine tree of the rosemary-leaved myrtle, growing in the south front of Mr. Upperton's house, at Sompting, two miles from Worthing, which is annually covered with blossoms. In September 1821, it measured eleven feet in height, and spread ten feet in breadth, the stem near the ground was eighteen inches in girth. This tree formerly belonged to $\mathrm{Mr}$. Whicher of Petworth, and is known to be considerably upwards of forty years old. The flowers of this variety are smaller, but not less beautiful, than those of the Roman myrtle, as its petals are agreeably proportioned to the size of its foliage.

We shall pass over the double-flowering VOL. II. 
myrtle, and other tender varieties, which belong to the green-house or conservatory,

Unconscious of a less propitious clime,

May bloom exotic beauty, warm and snug,

While the winds whistle and the snows descend."

COWPER.

The myrtle loves a warm dry soil, and is propagated by cuttings, which should be taken from vigorous young shoots, in July. These should be about five or six inches in length, and the leaves of the lower part stripped off, and the part twisted which is to be placed in the ground. The earth should be of a rich and light nature, and pressed tight to the cuttings. The pots should then be placed under the frame of a hotbed, and plunged either into some old dung or tanners' bark, to keep them moist. The pots will require water every few days; and carefully shaded from the sun, in about six weeks they will have taken root, when they should be gradually inured to the open air.

The double-blossomed, and other varieties of narrow-leaved myrtles, may be inarched upon the common kind; but this adds more to the curiosity of the plant than to its beauty. 
The Italian ladies still consider the tree of Venus to be favourable to beauty, and they therefore drop into their baths a water distilled from the leares of this tree; whose fragrance they prefer to the most costly essence of the Eastern nations.

OAK. - See Pomarium Britannicum. 


\section{PASSION FLOWER. - PASSIFLORA.}

Natural order, Cucurbitacea. Passiflorece, Juss. A genus of the Monadelphia Pentandria class.

"Les Grenadilles éclatintes,

Allongeant leurs flexibles mains,

Escaladent le front des plantes,

Et s'unissent à leurs destins."

Tris superb genus of climbing plants, of which we have now so splendid a collection in this country, was unknown before the treasures of the western world were discovered by Columbus. Its ancient American name is Murucuia, or Maracoc; but when first found by the Spaniards in South America, they called it Granadilla; from a resemblance they conceived the fruit to bear to that of the pomegranate, which is named Granadilla in Spanish. It appears to have been cultivated in Europe about the end of the sixteenth, or very early in the seventeenth century, as we find it pictured by Dr. Aldine, in 1620, from a plant that had flowered in the garden of 
Cardinal Farnesius; as also in a work that was published, in folio, at Rome, in 1625, under the title of "Exactissima descriptio rariorum quarumdam plantarum qua continentur Romce in horto Farnesiano. Tobias Aldinus Cesenatensis, Card. Odoardi Farnesii Medicus. It was also figured in a work, entitled, Theatrum Flore Johannis Robini, published at Paris in 1612, and by Parkinson, in 1629 , who tells us, that it had not then produced fruit in England.

When it was first introduced into Italy, superstition found a mysterious representation of the passion of Christ in this flower; and the crafty, who are always ready to impose on the credulous, soon turned this vegetable prodigy to account. The plant was pronounced a miraculous emblem of the sufferings of the Son of God, and received the sanctimonious titles of Fior della Passione, Flos Passionis, and Christi Passionis Imago. The leaf of the plant was expounded to be the spear which pierced the side; the twined thready substances of red and white, which form the crown of the flower, and which nature seems to have intended as a security for the nectar, were made to represent the lashes of the whip tinged with blood; the fine encircling stamens 
the crown of thorns; the column in the centre of the flower, a miniature of that, which served in the flagellation; the three clavate stigmas, the three nails used in the crucifixion.

To such a height was this ridiculous fantasy carried, that figures of the flowers were manufactured for devotional purposes, instead of the presumptive symbol; and so well did the makers of these religious flowers understand their trade of deceit, that they substituted iron nails for the stigmas, and a wreath of real thorns for the thready rays of the flower. But let us not from this anecdote judge too severely of the religious superstition of all the Italians; lest they should retaliate by representing us all as being sectaries of Johanna Southcott.

" Beneath the covert of o'er-arching trees, Bright Muruccia woos the cooling breeze. The passing Indian turns the admiring eye, Smit by the glories of her crimson dye, And stops in pleased attention to survey Her vivid leaves and variegated ray.

But loftier thoughts the rising mind inspire, When warm devotion lends her holy fire. Haply amid the convent's virgin train, Bosom'd in shades beyond the western main, At rosy morn, or evening's silent hour, Some fair Enthusiast views the sainted flower, When lo! to rapt imagination's eye, Springs the sad scene of darken'd Calvary! 
The thorny crown the heavenly brows around, The scourging thorns, the galling cords that bound, And nails that pierced with agonizing wound; Sudden she lifts to heaven her ardent eye In sileut gaze and solemu ecstacy;

'Then, fill'd with timid hope and holy fear,

Drops on the flower a consecrated tear."

Sнaw.

Linnæus changed the name of this genus of plants from Flos Passionis, by combining the words, into the technical name of Passiflora. This great botanist also ranged the plant in the natural order of Cucurbitacere, because the fruit has a nearer resemblance to the gourd family than that of any other fruit; but M. Jussieu has arranged it under a distinct order, since we have had so many species of this plant introduced into Europe.

The flesh-coloured passion-flower, Passiflora incarnata was the first variety known in Europe; but this is just too tender to endure the epen air of our country, though it is sometimes planted in the greenhouse for the sake of its fruit, which is of an egg shape, but more globular, varying in size from that of the pigeon to the duck. When fully ripe, it is of a colour between a grey and a dingy damascene, with a yellowish-green pulp. The flavour is slightly aromatic, and thought to partake of that of both the melon and the 
strawberry; but to us it appears more mawkish, and much inferior to either of these fruits.

The common or blue passion-flower, Passiflora corulea, which is found to thrive in the open air in England, is a native of Brazil, and was cultivated in this country by the Duchess of Beaufort, as long back as 1699, and is far more beautiful than the former variety. This species frequently sends out shoots of from ten to fifteen feet in one summer, and may be trained up more than forty feet high; and, as it is the most elegant climber known, no pleasure-grounds should be without it, either to cover trellis-work or a wall. It loves a south aspect, and will sometimes flower when permitted to climb trees that stand in warm sheltered situations. In the Brazilian forests these beautiful plants climb to the height of sixty feet, forming festoons from tree to tree, which are spangled with these brilliant stars in the most superb manner. Amongst the most conspicuous of these is the Passiflora racemosa, or bunch-flowered passion-flower. 'The petals of this species are of a fine crimson, and the rays of the crown purple, springing from a ring of a dark puce, regularly spotted with white, that has the appearance of a circle of pearls. The converging crown that covers the nectary is of a fine green. 
The corolla, before it expands, has the form of a balloon purse; and as the extremity of the branches hang loaded with the buds in a progressive state, it has a most lovely effect.

This species of passion-flower was observed by the late Mr. E. J. A. Woodford, growing wild in the shade of the woods, near the shore, about three miles from the city of Rio Janeiro. Mr. Woodford conveyed it to Lisbon, where he cultivated it with success. In its native country, it blossoms in November and December, producing generally two stems from the same stock, one of which proves fertile, and is without leaves, while in that state; the other remains barren and in leaf, but becomes fertile in its turn the succeeding year. It was thought that this beautiful plant could only be made to thrive in the stove; but we saw, in the summer of 1821, a fine plant of this kind in full flower, in a conservatory belonging to the Earl of Egremont, at Petworth. The petals of these flowers are keel-shaped, and when fully expanded each blossom measures from four to five inches in diameter, and it is perfectly without scent.

The square-stemmed passion-flower, Passiflora quadrangularis, is the most magnificent of all the varieties yet known; and the flowers 
which are the largest, display in colouring the happiest harmony combined with gaiety that can be conceived; the whole resembling a well disposed mass of gems, including all the tints of amethyst, ruby, garnet, topaz, turquoise, and emerald, sprinkled with jet and pearls. This fine flower requires the heat of a stove in our climate, but in the West Indies it is much cultivated as an ornamental climber for arbours and covered walks, for which its rapid growth, large foliage, and beautiful and fragrant bloom, make it admirably adapted; but the advantage of this splendid covering is more than counter-balanced by the danger which lurks in its shade, as it is said to be peculiarly liable to be infested by the most noxious serpents, who haunt it for the sake of the mice and squirrels that feed upon the fruit, and are the favourite prey of these reptiles. The fruit of this species of passionflower is nearly as large as the egg of a swan, but of a more oblong shape, and of a grateful sweetish acid taste. It is grown in great perfection in the hothouse of the Comtesse de Vandes, at Bayswater, near Kensington, and was cultivated in England as long back as 1760, by Mr. P. Miller.

The common passion-flower generally sends up numerous suckers, by which it is 
commonly increased. It may also be propagated by laying down the branches, which will be well rooted in one year, when they may be taken from the old plant, and placed where they are to remain. The cuttings will also take root, if taken in the spring before they begin to shoot, and planted in a loamy soil, not too stiff. These require to be covered with hand-glasses until they put out shoots, when air must be admitted to them. But the plants raised by these means seldom produce much fruit; and therefore it is more desirable to cultivate them by seed, which should be sown upon a good hotbed in the spring; and when the plants are fit to remove, they should be planted in small pots, filled with good kitchen-garden earth, and plunged into a bed of tanners' bark. The following spring they may be turned out of the pots, and planted against a wall in a south aspect.

POMEGRANATE.-See Pomarium Britanicum. 


\section{PINE. - PINUS.}

Natural order, Coniferce. A genus of the Monocia Monadelphia class.

"To loftier forms are rougher tasks assign'd, The sheltering oak resists the stormy wind, The tougher yew repels invading foes, And the tall pine for future navies grows."

BARBAULd.

Eтyмодogists differ considerably respecting the derivation of the generic name of this species of resinous trees. Linnæus places Pinus amongst the Latin names of unknown origin; and Martyn leaves it unexplained, in his splendid edition of Miller's Gardener's Dictionary; but the lexicographers are mostly content to refer to its Greek synonym $\pi$ irus; and it is possible that both words had the same source. M. Pirolle derives it from the Greek pitys, and Pinos from the adjective pion, fat, because they extracted pitch and turpentine from these trees; but De Theis deduces Pinus from the Celtic, and shows it to exist, variously modified, in all the dialects of that ancient language, its basis being pin 
or pen, a mountain or rock; whence we have the Apennines; the Pennine Alps, \&c. The Gallic pinwidden, like the German pyn-baum, means merely a mountain-tree.

The Greeks distinguished this species of deal-tree, from that of the fir and larch, by the name of Пвu'rn; but its use in naval architecture seems to have been the same as that of the former trees, from the earliest ages.

\section{Dant utile lignum}

Navigiis Pinus.

Georg. ii。

"The useful pine for ships."

It is impossible to behold these towering trees with indifference, that appear to be by nature intended to support the wings of our vessels; and thus enable us to enjoy the rarities of the most distant parts of the globe, with as much facility as if it had only been the produce of remote parts of our island. It is, therefore, with sensations of gratitude and pleasure that we should regard these resinous trees springing up, that are perhaps at some future day to be planted on the main for the defence of our country, or the maintenance of our commerce. This useful family of trees is generally found to prosper in soil and situations that would otherwise lie waste and barren, which is an important circum- 
stance, as they neither lessen our quantity of grain, nor occupy ground where the oak would thrive. We have already, in the history of the fir-tree, noticed the individual advantage that may be derived from forming plantations of this tree; and the benefit is not less in a national point of view, as the country cannot be enriched without contributing in some degree to the comforts of the most humble individuals, and we are decidedly of opinion, that there is no spot to be found in this nation, but what could be turned to profit if proper attention were given as to what kind of regetation was most suitable to the soil. We have still many thousand acres of land lying waste that would afford masts to all our vessels, from those which bring the finny tribe to our shores, to those which protect them by their wooden walls; and much as we dislike the sound of war, we would wish, in the midst of peace, to see our defensive weapons springing around us for future security.

The ornamental plantation, as a national advantage, is not duly appreciated; for it is in such situations that trees foreign to our soil have become naturalized, and their properties so made known to us, that we might judge how far their cultivation would answer 
in these kingdoms ; for as the change of climate affects quadrupeds, so that those which are removed from cold countries to warmer latitudes, lose a part of their warm covering, by their hair becoming short and thin, we may naturally expect a similar change in vegetables, whose fibres may become more firm or relaxed according to the countries from whence they are removed. It was in the pleasure-grounds that the common larch, which now makes so conspicuous a figure on the face of our poorest lands, was first raised; and the Weymouth pine, or New England larch, pinus strobus, was also introduced from North America by Lord Weymouth, and first planted to add grace to the grounds of the Duchess of Beaufort, in 1705. It was also planted at Sir E. Ḱnatchbull's seat in Kent, and some few other places, from whence the seeds have been principally obtained for the larger plantations that have been formed within the last fifty years. This species of pine is distinguished from others by the length of its setaceous foliage, of a bluish green, which is produced in little bunches of five out of each sheath. The cones are also of considerable length, and pendent, and the tree altogether forms the connecting link between the pine and the larch tribe. 
In its native country, it grows to the height of 100 feet, from whence great quantities of this timber are imported, under the name of white pine; and so much has it been esteemed for naval purposes, that there was a law made in the ninth year of Queen Anne for the preservation of the trees, and to encourage their growth in America.

In 1736, a tree of this species was cut down on the banks of the river Merimack, that was seven feet eight inches in diameter at the butt end ; and it is now ascertained that this tree, as well as the Scotch fir and the common larch, produce a profitable and serviceable timber when planted in British soil.

In flat countries, where the timber-trees are principally oak, or other round-headed kinds, a few of these pines, by their spiry tops, give force and character to the heavy and dull sameness of the scene; and when towering over the trees of the forest, they break the uniformity of the sky outline, with an effect similar to that which the spires of churches give to towns and villages. In hilly situations, the pine plantation should occupy the most elevated spot, as it adds considerably to the grandeur of such scenery, and throws a softness on the valleys below, by the contrast of colour. 
The want of judgment and taste in planting these trees, in little courts and gardens before the fronts of houses, where there is scarce room for a lilac or cherry-tree to thrive, is too conspicuous in most parts of the country, and is scarcely less ridiculous than a pair of jackboots would appear at a dress-ball.

The Weymouth pine grows best upon a moist light soil, not too wet: it will also thrive on a loamy soil, if it does not approach too near to clay. When planted in a soft, hazel loam, it often makes shoots of thirty inches in one year; but it is not so well adapted to exposed situations, as the Scotch fir or the larch, and the seeds require to be sown with a little more care than those of the latter trees, that is, by giving them more sheltered spots, or by shading the young plants with. mats from the sun, but which should be removed so as to admit the dews of the night. 
ORIENTAL PLANE.TREE.-PLATANUS.

Natural order, Amentacea. A genus of the Monœcia Polyandria class.

- When the sun begins to fling His flaming beams, me, goddess, bring To arched walks of twilight groves." MiltoN.

"His spreading planes their pleasant shade extend, Where he enjoys his bottle and his friend."

LAUderdale's Virgil.

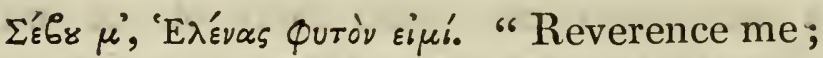
I am the tree of Helen." Thus Theocritus represents the virgins of Sparta, singing in the Epithalamium of their princess, who afterwards caused her husband, her handmaids, and her country so much woe.

This beautiful Asiatic tree, which the ancients consecrated to the Genii, seems to have bewildered the mind of Xerxes, as much as the beauty of Helen had overpowered the reason of Paris, for Elian tells us very seriously, that this Persian monarch was so attracted by the charms of a plane-tree which he found in Phrygia, that he caused his prodi- 
gious army of 1,700,000 soldiers to halt whilst he adorned the tree with all the jewels belonging to himself, his concubines, and the principal men of his court, until the branches were loaded with gems, necklaces, bracelets, scarfs, and ornaments of every kind. He called it his mistress and his goddess, and it was some days before he could be prevailed on to leave the tree of which he was so enamoured, and even then he caused a figure of it to be stamped on a gold medal, which he constantly wore about him. Herodotus relates that he encircled this favorite tree by a fence of gold, and that he appointed one of his suite to guard it. We are more disposed to consider that Xerxes had some political cause for this action, more than the bare infatuation which the beauty of the tree could create, unless it recalled to his remembrance some interesting circumstance of his life that was dear to his heart.

The Greeks named this tree $\Pi \lambda \alpha^{\prime} \tau \alpha \nu \circ$, from $\pi \lambda \alpha \tau$ is wide, on account of the wide spreading of its branches, for which, and for the beauty of its shade, it was so greatly esteemed at Athens, that it formed the principal shade in the groves, where the philosophers of that city held their discourses or retired to study.

The plane-tree was always planted on the 
plots allotted to the gymnastic games of the city, and the porticoes of its sumptuous buildings generally terminated in groves of these trees.

The Romans named this fine tree Platanus, from the Greek, and they seem to have held it in equal veneration with their more eastern neighbours, for we read in Pliny that when it was first introduced into Italy, they irrigated the roots with wine instead of water. This author informs us that it was first brought over the Ionian sea, into the island of Diomede, where it was planted to ornament the tomb of that hero.

Dionysius the Tyrant brought the planetree into Sicily, from Rhegium in Calabria, about 400 years before the Christian era.

This tree was so highly esteemed when first introduced into France, that none of the natives were allowed to repose under its shade, without paying a tribute or tax for that purpose to the Romans.

The oriental plane-tree is thought to be so great a purifier of the air, as even to defend places which it surrounds from the plague. Evelyn says, "A worthy knight, who staid at Ispahan, in Persia, when that famous city was infected with a raging pestilence, told me, that since they have planted a greater number 
of those noble trees about it, the plague has not come nigh their dwellings." The Turks in Constantinople seem to enjoy no greater luxury than that of reclining under the umbrageous boughs of these majestic trees, and smoking their tobacco in a state of perfect indifference to all sublunary things.

From accounts which we have lately received from the Sublime Porte, we conclude that no part of Europe can boast of such gigantic trees as the planes which are to be found in that neighbourhood. Lady Craven also speaks of some which she saw in the Turkish dominions, of such magnitude, that the largest trees we have in England, placed near them, would appear only like broomsticks.

It is to be regretted that no just calculation can be formed as to the age of these celebrated trees, which are only second in dignity and durability to the cedars of Lebanon. The Turks, who lop off heads with as much indifference as our gardeners cut their cabbages, preserve these trees with a religious tenderness.

Pausanias, a celebrated historian, who flourished about the middle of the second century, tells us of a plane-tree of extraordinary size and beauty in Arcadia, supposed to have been planted by Menelaus, the husband of 
Helena, which would make the age of the tree about 1300 years.

Pliny also records the particulars of several remarkable plane-trees, and tells us of one in Lycia, that had a cave or hollow in the trunk, which measured 81 feet in circumference, in which were stone seats covered with moss, and that Licinius Mutianus, when consul, with eighteen of his friends, used to dine and sup in the cavity of the tree, the branches of which, we are told, spread to. such an extent, that this single tree appeared like a grove, and this consul, says our author, preferred sleeping in this hollow tree to his marble chamber, where his bed was composed of curious needlework, and canopied with beaten gold. Caligula, the tyrannical emperor, who was murdered in the year 41 , A. D. had also a similar plane-tree in Velitra, which he called his nest, in the cavity of which, this haughty Roman and fifteen of his debauched courtiers used to sit and dine, leaving ample room for his train of attendance to wait on the party.

The peasants about Apamia and Phrygia showed a large plane-tree, on which they affirmed Marsyas was hanged up, and flayed by Apollo, who was incensed at his presumption, in pretending to contend with him in music. Fable pictures to our view 
"The Satyr's fate, whom angry Phœbus slew,

Who raised with high conceit, and puff'd with pride,

At his own pipe the skilful god defied.

'Why do you tear me from myself?' he cries;

'Ah, cruel! must my skin be made the prize?

This for a silly pipe?' he roaring said,

Meanwhile the skin from off his limbs was flay'd."

Croxall's Ovid.

The oriental plane-tree called dulb by the Arabians, appears to have been first introduced into England about the middle of the sixteenth century, as Turner says in his Herbal of 1568, "I have sene two very yong trees in England, which were called there Playn trees. Whose leues in all poyntes were lyke vnto the leues of the Italian Playn tre. And it is doutles that these two trees were either brought out of Italy, or of som farr countre beyond Italy, wherevnto the freres, monkes, and chanones went a pylgrimage." Gerard does not notice having seen the plane-tree in this country in 1597; but he tells us that his servant, William Marshall, whom he sent as surgeon in the Hercules of London, found these trees growing in Lepanto in Greece; from whence, says Gerard, "he brought one of those rough buttons, being the fruit thereof."

Our noble philosopher, Bacon, seems to have been one of the earliest planters of the 
plane-tree in this country; but that he was not the first we have already shown from Turner. Evelyn says, "The introduction of this true plane among us is, perhaps, due to the great Lord Chancellor Bacon, who planted those (still flourishing ones) at Verulam; as to mine, I owe it to that honourable gentleman, the late Sir George Crook, of Oxfordshire, from whose bounty I received an hopeful plant now growing in my Villa."

Goodwood Park in Sussex has long been celebrated for containing one of the finest oriental plane-trees in Europe, excepting perhaps those in the vicinity of Constantinople.

Miller notices that there were very few large oriental plane-trees to be seen in this country; which he thinks might be owing to the great esteem persons of the last age had for the lime-tree, which being much easier to propagate, and of quicker growth during the first three or four years; became more fashionable for avenues and shady walks near habitations. As the stately avenues have now nearly disappeared, we may perhaps see this celebrated tree of the ancients become fashionable again in our plantations, for although it is late in putting forth its leaves, and sheds them again early in the autumn, 
yet no tree affords a more agreeable shade than the plane, during the summer months; and it is worthy of remark, that the foliage of this tree, like that of the lilac, mulberry, and walnut, which are also eastern trees, is never injured by insect or blight. The eastern plane-tree has also the quality of cleansing its trunk from moss and other parasitical incumbrances, by annually throwing off its bark.

The leaves of the plane-tree are about seven inches long, and eight inches wide, deeply cut into five segments, and are what are termed palmated leaves: the upper surface is of a deep green, and the under side pale. The flowers come out upon long peduncles, hanging downward; and the seed or fruit is of a globular shape, and gracefully suspended from the branches, until it falls to pieces; when the seeds, which are covered by a kind of down, are transported to a considerable distance by the wind. Thus nature has provided them with wings, that as they require much room for their growth, they may be scattered thinly over the country.

"'There lives and works

A soul in all things, and that soul is God, The beauties of the wilderness are his."

Cowper.

The plane-tree seems designed by nature 
to stand singly, for its lower branches shooting horizontally, soon take a direction to the ground, and offer a more delightful retreat from the midday sun, than any tree in the park. We have frequently remarked that this Asiatic tree thrives better in the smoky atmosphere of our metropolis than most other trees; which should induce the planters, in the immediate vicinity of London, to cultivate it more generally. Dr. Hunter tells us, that a plane-tree which was eight feet high, was planted at Shadwell Lodge, in Norfolk, the seat of John Buxton, Esq., in April 1744, which in April 1775, was sixty-five feet nine inches high; the girth at half a foot from the ground was seven feet nine inches; at twenty feet, four feet six inches.

Ricciolus says that the Turks used to build most of their ships with this timber. It is said to be close and hard, and to take a fine polish; and is useful for a variety of purposes. It is raised generally from layers, but these seldom produce so fine trees as those obtained from seed, which should be sown when ripe, in a moist and shady situation. This tree may also be propagated by cuttings, which should be planted early in autumn in a moist, good soil.

The American plane-tree, platanus occi- 
dentalis, grows naturally within the same latitudes in the western world, that the platanus orientalis flourishes in the East. The American plane appears to have been known to us about two hundred years, as Johnson says in his edition of Gerard's Herbal, printed in 1633. "There are two young ones at this time growing with Mr. Tradescant;" and Parkinson states, that "the American planetree was introduced by Mr. John Tradescant, jun."

This species of plane-tree is now much more common than that of the East, although it is not superior to the latter in any particular. Mr. Gilpin tells us, that one of the finest occidental planes stood in his garden at Vicar's-hill, where its boughs, feathering to the ground, formed a canopy of above sixty feet in diameter.

These trees love a moist soil, and should therefore be plentifully watered when young, which will ensure them as rapid a growth in modern times, as the irrigating them with wine did in ancient days.

Tantumque postea honoris increvit, ut mero infuso enutriantur: compertum id maxime prodesse radicibus; docuimusque etiam arbores vina potare.-PLIN. 
POPLAR.-POPULUS.

Natural order, Amentacec. A genus of the

Diøcia Octandria class.

". And poplar, that with silver lines its leaf." Cowper.

" The poplar is by great Alcides worn." VIRGIL.

"A double wreath Erander twined,

And poplars black and white his temples bind." . Ів.

These towering aquatic trees, which the

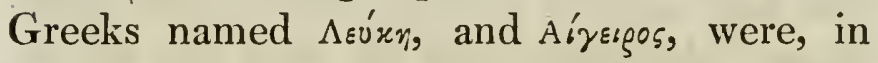
ancient times, held sacred to Hercules, who wore a crown, composed of the foliage of the poplar, in his descent to the infernal regions. The ancients, who had a fable for every subject for which they could not find a philosophical reason, thus accounted for the different hues which the leaf has on its opposite sides. The leaves of which the hero's crown was composed, on the side next his head, retained their natural pale colour, or, as some say, received that pallid hue from the perspiration of his brow; but the other side, being exposed to the smoke and noisome vapours of the dismal dominions he was visiting, took a darker tint, which they still retain. 
The poplar was dedicated to Hercules, in consequence of his destroying Cacus in a cavern adjoining to the Aventine Mount, where these trees formerly abounded.

" From that blest hour th' Arcadian tribe bestow'd Those solemn honours on their guardian god. Potitius first, his gratitude to prove, Adored Alcides in the shady grove; And with the old Pinarian sacred line These altars raised, and paid the rites divine, Rites, which our sons for ever shall maintain; And ever sacred shall the grove remain. Come, then, with us to great Alcides pray, And crown your heads, and solemnize the day. Invoke our common God with hymns divine, And from the goblet pour the generous wine. He said, and with the poplar's sacred boughs, Like great Alcides, binds his hoary brows."

PitT's Virgil.

All those who had gloriously conquered their enemies in fight, wore a garland of the branches of the white poplar, from the example of Hercules. *

It is related that Homer first recited his matchless verses beneath a poplar. This king of poets says, in the Iliad, that the buckler of Ajax, son of Telamon, was made by a skilful workman of Hyle, named Tychius ; and, it is pretended, that it was through gratitude that

* The altar of Hercules, Ara Maxima, was at Rome, between the Aventine and the Palatine mountains, in the open place called Forum Boarium (the ox market). 
Homer made mention of this artist, because, when in want of subsistence, this great poet had been kindly received and treated by a currier of Hyle, in Bœotia, named Tychius; and for many ages the place was shown where Homer recited his verses to his host, under the shade of a poplar. From the beautiful manner in which the author of the Iliad compares the fall of Simoïsius, by the hand of Ajax, to a poplar just cut down, we may conclude that it was a favourite tree with this celebrated Greek writer. Pope thus translates the verse :

"So falls a poplar, that in watery ground Raised high the head, with stately branches crown'd, (Fell'd by some artist with his shining steel, To shape the circle of the bending wheel)

Cut down it lies, tall, smooth, and largely spread, With all its beauteous honours on its head."

Ovid notices the poplar as the tree on which lovers wrote their verses. In the epistle from OEnone to Paris it is thus mentioned:

" There grows a poplar by the river side,

Whose trunk engraved records my once loved name:

Live, poplar, live, that wavest o'er the tide

With this memorial of my lover's shame:

- When Paris flies, and reckless of his love,

- Can breathe unblest by his OEnone's eyes,

- Then Xanthus backward from his course shall move,

" And to their fountain-head his waves shall rise."

H. P. jun. 
The poplar is a native of Europe, and has been found growing naturally near rivers and brooks from Italy to Sweden, as well as in Siberia and Barbary:

"The stately poplars o'er our fields that grow, Admit their brethren from the distant Po."

Delille.

The banks of the Po have ever been celebrated for these spiral trees, on which account some writers have thought that the sisters of Phaeton were changed into poplars; but this does not appear from Ovid, as we have noticed in the history of the larch, yet it is slightly alluded to by Virgil in the 10th book of the Aneis :

" For Cycnus loved unhappy Phaeton, And sang his loss in poplar groves, alone, Beneath the sister shades."

Sterne, in his Sentimental Journal, has pictured Maria sitting under a poplar, in such forcible melancholy colours, that when we see this tree in rural situations by the side of a brook, we almost expect to meet the " hapless damsel," or hear " the evening service to the Virgin," or a tale of woe, told by the "sweetest notes" of her plaintive pipe :

"6 'Twas near a thicket's calm retreat,

Under a poplar tree,

Maria chose her wretched seat,

To mourn her sorrows free." 
Notwithstanding that we might avail ourselves of the authority of the British Botanist, and the able compiler of the Hortus Kewensis, for claiming both the white and the black poplars as natives of this country; yet, from our own observations, and the remarks of our oldest writers on the subject, we do not feel justified in pronouncing both of them aboriginals of our soil. Turner says, in 1568, "As touching the whyte asp, I remembre not that euer $\mathrm{I}$ saw it in any place of England. But I haue sene it in great plentye in Italy, by the ryuer sede of Padus; where, as it is called albera, and in hyghe Germany by the reuer syde, where as it is called saurbaum. If it be found in England, it may be called a whyte asp, or a whyte popler." Gerard, who wrote about thirty years after 'Turner, says, "The white poplar groweth not very common in England, but in some places heere and there a tree: I found many both small and great growing in a lowe medow turning vp a lane at the further end of a village called Blackwall, from London; and in Essex at a place called Ouenden, and in diuers other places." We do not find any old English name for these trees, as the word poplar is as evidently from the Latin populus, or the French peuplier, as the name of abele is from the low Dutch 
abeel, a name which they gave to this tree on account of its hoary or aged colour.

The Lombardy or Po poplar, populus dilatata, whose tapering form so conspicuously marks it from all other deciduous trees, is said to have been first introduced into this country by the Earl of Rochford, who planted it in Essex, about the year 1758; since which time it has, from its easy propagation and quick growth, spread itself throughout the country; and on this account it is not generally admired, because we too often meet with these vegetable grenadiers injudiciously planted, either in single rows, or in enclosing small gardens, and for which we have but few trees worse calculated.

The planting of the Lombardy poplar should have been confined to the hand of the landscape planter, when we should have found it one of the greatest ornaments of our sylvan scenes, as its shape contrasts so singularly with our native forest trees, without any offensive harshness, and particularly when it rises in clumps of two or three trees in the midst of the plantation. In some situations we have found a detached poplar give good effect, and in others a plantation of them have added considerably to the beauty of extensive grounds; but so much depends on the

VOL. II. 
general arrangement of the groves, and the undulation of the ground, that it is scarcely possible to give directions where to plant this Italian tree, without being on the spot. However, we may venture to recommend its being planted in places where it is desirable to break the uniformity of the sky line. This tree possesses one beauty peculiar to itself, which is its waving mien when agitated by the wind, for its whole body bows in as graceful a manner as the bending corn; whilst other trees have only their foliage, or smaller branches, mover by the air, and although it does not catch masses of light in the happy manner of the elm, yet the quivering playfulness of its foliage is both agreeable to the eye and the ear.

The value of different timber-trees in different countries, depends greatly on the customs and habits of the people. In the plains of Naples, where there is a demand for this soft wood, it is customary for a peasant, on the birth of a daughter, to plant a row of poplar trees, which are cut down and sold at the end of seventeen years, to make up a fortune for her ; for it is not customary in that country for a young man, however poor he may be himself, to take a portionless wife.

In many parts of Italy, the poplar is still 
planted as a support to the climbing vine; and the vine-dresser may now be seen, as of old, swinging on a rope, formed of twisted willows, whilst lie trims up the poplar, or prunes its luxuriant spouse; and his voice is still heard abusing the lads and lasses, as they return from market, with the same gross wit and low jests that gave such zest to the farces of Atella in ancient times.

In Lombardy, all the vessels in which the grapes are carried from the vineyards, are formed of poplar planks, of about two inches thick, and in them the grapes are squeezed. These vessels are said to last from thirty to forty years; and their lightness is also a considerable recommendation, as these troughs are often of a size that will contain upwards of fifteen hundred weight of grapes.

We are assured that thirty acres of this wood, when fit to cut, are worth in Italy about four thousand pounds. The trunk of the poplar, when about two feet in diameter, and thirty feet in length, which size it attains in about seventeen or eighteen years, is sold in Lombardy to the dealers for twelve or fifteen shillings. It is cut at the water-saw mills whilst green, into thin boards, for packers of bales of woollens, boards to put in the middle of silk pieces, or other manufactures, and also 
for boxes and packing cases, as the lightness of the wood saves much expence in carriage, and nails do not split the poplar plank, which is also a recommendation to this wood, and it rather gives way than splits when thrown to the ground.

The timber of the Po poplar is said to be inferior to the common black poplar, but it is in demand for many purposes where soft wood is required, and vast quantities of wooden shoes are made from it in France and other parts of the continent. It answers tolerably well for floors and other purposes where it is not exposed to the weather. For packing cases we can have no better wood, which will always ensure it a good sale in this mercantile country.

A correspondent in Young's annals affirms, that this kind of poplar is fit to cut for building purposes in twelve years, and that at eight years' growth, it is forty feet high. For rafters, small beams, studs, boards, \&c. he says, they have stood sixteen years without the least decay, having been brushed over with oil, tar, and brickdust laid on hot.

The growth of this tree, like that of most others, depends upon the soil and situation in which it is planted. Mr. Young, in his Irish tour, mentions some Lombardy poplars 
which grew to the height of thirty-five feet in five years, and many at two years old to the height of twelve feet. Martyn says, "I have measured one of my own trees, which has been planted about twenty-five years, and find that it measures six feet five inches round, a foot above the ground, and six feet, at the height of five feet; it is sixtythree feet five inches high, and has not increased so much in height as in girth, for some years past."

The most extraordinary trees of this kind that we have seen, were in a swampy situation on the borders of the Seine, near Rouen, in Normandy, where they seemed aspiring to reach the height of the towers of the cathedral of that city. These trees had not been planted more than about twenty years; yet their height is such, as to make it quite awful to walk in the avenues. The moisture of the soil in which they are planted, and the height of the mountains that shelter them, have both contributed to draw them up in an extraordinary manner.

In some parts of Flanders great profit is made by planting the common kinds of black and white poplar ; and the like advantage would be made in this country, were more attention paid to planting these trees in boggy 
and waste lands, where neither corn or grass will prosper; but it seems a fashion rather to let these plots of ground lie waste, than to plant them with trees to which the soil is suitable, although, if their speedy growth and small expense in planting be taken into consideration, it would be found perhaps more profitable by making quick return, than the oak or elm, which require good soil and ages to render them advantageous. Poplars have been known to drain moist ground so effectually, and to manure it by the fall of their leaves, so as to render it fit for meadow or pasture land.

These trees are propagated by cuttings, which should be planted in the spring; they should be taken from the most vigorous shoots of the last year, or at most, not above two years' growth; these should be planted about a foot deep in the earth, and it is advisable to rub off all the side shoots for the first year or two which gives strength to the young plants.

All the kinds of poplar are alike bad wood for fuel, as it rather roasts away than burns, giving a great deal of smoke, but no flame. On this account it is desirable for building of cottages and stables, \&c., as the boards are so slow in taking fire, that the flames are said 
to have been stopped at that part of a building on fire, where this timber had been used.

We shall pass over in silence the many books that have been written on the medicinal qualities of every part of this tree, as we do not find that our forefathers were exempt from the pains of the gout, although they assure us, that the leaves of the poplar are an infallible cure for this vexatious complaint.

The buds of both the white and the black poplar, have an agreeable perfume early in the spring, and when pressed between the fingers yield a balsamic resinous substance, which extracted by spirits of wine smells like storax.

The flowers of the poplar have but little attraction, excepting to the bee and the botanist ;

"Swung in the wind the poplars nod in love;"

whilst the bee collects the superfluous pollen to convert into waxen cells.

Scheffer, whose industry and ingenuity almost equalled that of the inhabitants of the hive, collected the cotton down which covers the seeds of these trees, and converted it into paper. 
PORTUGAL LAUREL. - PRUNUS LUSITANICA.

Natural order, Pomacea. Rosacer, Juss. A genus of the Icosandria Monogynia class.

"Hail, Albion, native country! See, how changed Thy once grim -aspect ! how adorn'd and gay Thy howling forests, where together ranged The naked hunter and his savage prey!" West.

THis beautiful evergreen, which is one of the greatest ornaments of our shrubbery, was first obtained from Portugal, on which account it is called the Portugal laurel, although it is very doubtful whether it be a native of that soil. The French name it Laurus Maderiensis, and in their own language, Laurier de Madire; and we are disposed to believe, that it is indigenous to the Azores as well as Madeira. The Azores lie in the same latitude with Portugal, and the Portuguese name for this plant is Azoureiro, which strongly indicates their having procured it from these islands. 
Knnowlton's manuscripts inform us, that it was first cultivated in this country by $\mathrm{Mr}$. Thomas Fairchild, in 1648.

Miller, who calls the common laurel the cherry-laurel, calls this species the cherrybay, and he observes, in 1724, that, " it holds out our hard winters best on our coldest and openest grounds, and is a glorious tree for standards on most grounds."

It is with great delight we see, of late years, even our native woods interspersed with exotic timber-trees, and in many instances embellished with foreign flowering shrubs. The forest of St. Leonard's, in Sussex, which we remember a most gloomy and desolate waste, the retreat of footpads and contraband dealers, is now become one of the most embellished parts of the country; and we behold with surprise, groves of valuable timber spring up in spots where we were formerly told a rabbit could not find subsistence.

"Waste sandy valleys, once perplex'd with thorı, The spiry fir and shapely box adorn."

Pope.

'These agreeable metamorphoses are principally owing to the spirited manner in which the grounds have been cleared and planted by Lord Erskine, Charles George Beauclerc, 
Esq., John Aldridge, Esq., George Matcham, Esq., - Knowles, Esq., - Sugden, Esq., and others; who will eventually reap as profitable a harvest from these sylvan scenes, as they collect from their richer valleys where Ceres reigns; and we may add from Crabbe,

"Thy walks are ever pleasant; every scene Is rich in beauty, lively, or serene-

Rich - is that varied view with woods around, Seen from the seat, within the shrubbery bound."

The Portugal laurel has hitherto been planted only as an ornament to the shrubbery; but we would strongly recommend its being cultivated in the forest we have just noticed, as well as in other plantations; and not for its beauty alone, but for its fruit also, which is, as well as the fruit of the common laurel, the favourite food of the pheasant. It is desirable to draw these beautiful birds from the fields of the farmer, by furnishing them with food in our forests; and it is well known that birds which feed on berries have a much finer flavour than those that are bred in cornlands.

Pheasants are natives of and originally came from the same spot from whence the common laurel was first brought, that is from the banks of the ancient river Phasis that 
flows into the Black Sea, and from which they received their name, being called by the Greeks Фaravòs. The Latin phasianus is the same, and our pheasant, and the French faisand, have the same derivation.

The Portugal laurel ripens its fruit in October, which is a drupe of a dark purple colour and spicy flavour. The seed is contained in a nut or stone similar to that of the cherry, but more pointed at the top, and smaller than that of the common laurel. The wood of the Portugal laurel appears to be nearly as hard as that of box ; and as it grows with a strong tree-like stem to the height of twenty or thirty feet, it may turn to account as a substitute for box-wood.

It has a fine effect in the plantation during the month of June, when it is often covered with long pendent racemes, or strings of white rosette flowers, opening in succession from the top of the flower-stalk, whilst the buds are gradually diminished to the end, like pearlbeads set in the most graceful manner. The branches are covered with a shining purplish bark, and the young wood and leaf-stalks are of a fine red tint, which contrast most happily with the lucid green of the upper surface of the leaf; whilst it harmonizes in an equally agreeable manner with the pomona green of 
the under side. These leaves hang much more gracefully than those of the common laurel, and are not so liable to be injured by the frost in severe winters.

The severe winter of 1740 , which killed most of the common laurels, scarcely affected the Portugal laurel, and although these shrubs were injured by the frost in January 1776, most of them recovered when cut down. They love a loose moist soil, not too wet, but will thrive in most kinds of earth ; although they do not prosper so well when planted in a very dry soil, or in ground that is over wet. The finest trees are raised from seeds, as they are then more disposed to take an upright growth. To obtain the seeds perfectly ripe, it is necessary to protect them from the birds. They should be sown in drills as soon as gathered; for if kept until the spring, they will not germinate until the second year. It is advisable to cover the beds with any light litter that will protect the ground from the frost, and to keep the young plants moist by watering should the summer prove dry, by which means they will be fit for transplanting the following autumn.

The best season for propagating these trees by cuttings is about the end of September, as soon as the autumnal rains fall to moisten 
the ground. The cuttings should be from the same year's shoots, and if they have a part of the former year's wood to their bottom, they will more certainly succeed, and form better roots. They should be planted about six inches deep, and the earth pressed close to them. When increased by layers, the young branches should be laid down in the autumn, and they will take root in one year, when they may be detached from the parent stock, and removed to the nursery. 


\section{PRIVET. - LIGUSTRUM.}

Natural order, Sepiario. .Jasminece, Juss. A genus of the Diandria Monogynia class.

"Alba ligustra cadunt, vaccinia nigra legunur." VIRGiL.

" Nor will the breast where fancy glows Deem every flower a weed, that blows Amid the desert plain."

Shenstone.

"But who their virtues can declare? who pierce With vision pure, into these sacred stores Of health, and life, and joy." ThOMSON.

This native shrub is one of the prettiest ornaments of our hedgerows, which it continues to embellish for a longer period than most other plants; for, although it is deciduous, the leaves seldom fall until thrust off by those of the succeeding spring. And its spike-formed thyrsi of white monopetalous flowers, which in shape resemble those of the lilac in miniature, are in blossom from the beginning of May to the end of June, agreeably perfuming the hedges; and its clustering bunches of deep purple shining berries garnish the spray of this shrub during the whole 
winter, affording food to the bullfinch and thrush, and a

"Fit dwelling for the feather'd throng,

Who pay their quit-rents with a song." .Green.

The leaves of the privet feed the sphynx ligustri, or privet hawk moth; and the phalcena syringaria is also nourished by it in the caterpillar state; and meloe vesicatorius, cantharides, or blister-beetle, is found on it.

The leaves being bitter and slightly astringent, are but seldom eaten by cattle; horses refuse it entirely, but kine, sheep, and goats, will sometimes browse on it.

It is a valuable plant in the shrubbery, as it grows well under the drip of trees, and bears clipping, which makes it desirable in those situations where it is necessary to form hedges, either for shelter or ornament, and as it has only fibrous roots, it impoverishes the ground less than any other shrub.

The privet is not liable to be injured by insects or blight, and it is found to be one of the few plants that will thrive in the smoky atmosphere of the squares or gardens of London, but it seldom produces flowers in these confined situations. In open places it arrives to the height of six or seven feet, and the 
wood becomes hard and fit for the use of the turner.

We learn from Pliny, that the berries of this shrub were in ancient times given to chickens to cure them of the pepia, or pip, a disease that often destroys whole broods of poultry, and which is caused by a thin white skin or film that grows under the tip of the tongue, and hinders their feeding. It usually arises from want of water, or from the drinking of puddle-water, or eating filthy meat. It may be cured by pulling off the film with the fingers, and rubbing the tongue with salt. Hawks are particularly liable to this disease, especially from feeding on stinking flesh.

"See man from nature rising slow to art!

To copy instinct then was reason's part;

Thus then to man the voice of nature spake Go, from the creatures thy instruction take:

Learn from the birds what food the thickets yield;

Learn from the beasts the physic of the field."

Pope.

Old medical writers tell us that the leaves and flowers of privet are cooling, drying, and restringent, good for ulcers and inflammations of the mouth and throat, bleeding of the gums, and relaxation of the uvula.

The leaves of this plant give a faint tinc- 
ture of red to blue paper; but the flowers and fruit give it much deeper. From this and the chemical analysis, it was conjectured that there was an aluminous salt involved in a great deal of sulphur in the leaves, but that this salt is very much disengaged from it in the flowers and fruit. It yields a great quantity of oil and acid liquor by distillation, as well as a little urinous spirit. All these principles mixed together, are thought to render the privet very detersive.

The gargarisms made of the juice or distilled water of this plant, were formerly much used for the diseases of the throat, as they were supposed to dry away ulcers, and also to assuage the inflammations of the eyes, and scalds, \&c., and were said to stop the spitting of blood, and cure hæmorrhages.

This plant is indigenous to most temperate climes, but it is said not to be found in Poland. The Greeks called it $\Phi, \lambda$ $\lambda$ upéa (Phillurea), the Latins Ligustrum, the Arabians Mahaleb. In Spanish it is named Alfena and Alhena, in Portuguese Alfena, in Italian Ginstrico, in German Liguster Rheinweden, and Mundholtz, in Russian Schost, in Dutch Keelcruyt, in French Troëne, and in English it was formerly called Prim, Print, and Primprint, from being, as is supposed,

VOL. II.

L 
kept clipped in a neat manner. Parkinson tells us that it was used to cover arbours, bowers, and banqueting-houses, and he adds, " it is wrought and cut into many formes of men, horses, birdes, \&c. as the workmen list, supported at the first with timber, poles, and the like, but afterwards groweth strong of itselfe, sufficient to hold it in the forme it is made into." The same author tells us, that the berries were dried with the young branches, and ground into powder, which formed a considerable article of commerce with the Turks, who used it to give a yellow colour to their hair, hands, and nails, and that they also dyed their horses' manes and tails with this powder, to make them gay on festival days.

The Italian or evergreen privet, is now generally supplied by our nurserymen, as it is equally hardy and the flowers something larger; but this variety seldom produces fruit in England, and therefore is not so valuable in the plantation as our native kind of privet.

The best plants are raised from seed, which should be treated in the same manner as the direction given for sowing the holly-berries. It is easily propagated by laying down the young shoots in autumn, and it may be increased also by cuttings, as well as by the suckers, which it sends forth in great plenty. 
The foliage of this shrub is of a purplish green, and it agrees well with the yellower tints of the common laurel. When planted with box or other dwarf evergreens, its clusters of shining berries have a good effect in the winter months.

From the pulp of the berries, a rose-coloured pigment may be prepared. With the addition of alum, they dye wool and silk of a good durable green; for this purpose they must be gathered as soon as ripe. 


\section{ROSE.-ROSA.}

Natural order, Senticose. Rosacea, Juss. A genus of the Icosandria Polygynia class.

"I am the Rose of Sharon." Solomon's Song, ii. 1.

"The wilderness and the solitary place shall be glad, and the desert shall rejoice and blossom as the rose."

IsAIAH, xxxv. i.

"The nightingales warbled their enchanting notes, and rent the thin veils of the rose-bud and the rose." J JMI.

"Rose! thou art the sweetest flower

That ever drank the amber shower;

Rose! thou art the fondest child

Of dimpled spring, the wood-nymph wild!

Even the gods, who walk the sky,

Are amorous of thy scented sigh ; -

Cupid too, in Paphian shades,

His hair with rosy fillet braids."

Moore's Anacreon, Ode 44.

" The rose abashed, with a comely blush

Unveils her virgin cheeks, and to the gods

Due honours pays, and with its fragrant smell,

Sabean odours like, perfumes their domes."

Columella, lib. $\mathbf{x}$.

“ Non è, non è la porpora

De la Monzese rosa,

Non e de la muscosa

Il vermiglio gentil. 
Par quel langour vezzeggiano

- Le piu soavi aurette,

Ne miglior don permette

A Vergin crine April.

Esce da l'umil calice

Cinnamomea fragranza,

Onde l'indica stanza

Flora cotanto amò.

E Nice, che in lei beasi,

Sorride in cuore e pensa,

Che ben virtù compensa

Quando beltà mancò."

Montani.

" Aimable rose! an lever de l'aurore,

Un essaim de zéphyrs badine autour de toi;

Chacun d'eux jure qu'il t'adore,

Chacun d'eux et promet une éternelle foi.

Mais le soleil, en se couchant dans l'onde,

Voit à leurs tendres soins succéder le mepris:

La troupe ingrate et vagabonde

Te déserte sans scrupule arec ton coloris.

Les Amours de Leucippe.

" Thy scented buds life's joys disclose,

They strew our paths with magic sweets,

Where many a thorn like thine, fair rose,

Full oft the weary wanderer neets :

And when he sees thy charnis depart,

He feels thy thorn within his heart."

Mrs. M. Robinsox.

'THE rose, which is the emblem of beauty and the pride of Flora, reigns queen of the flowers in every part of the globe; and the bards of all nations and languages have sung its praises. Yet what poet has been able, or

L 3 
language sufficient, to do justice to a plant that has been denominated the daughter of heaven, the glory of the spring, and the ornament of the earth?

As it is the most common of all that compose the garland of Flora, so is it the most delightful. Every country boasts of it, and every beholder admires it; poets have celebrated its charms without exhausting its eulogium, for its allurements increase upon a familiarity, and every fresh view presents new beauties, and gives additional delight. Hence it renovates the imagination of the bard, and the very name of the flower gives harmony to his numbers, as its odours give sweetness to the air.

To paint this universal emblem of delicate splendor in its own hues, the pencil should be dipped in the tints of Aurora, when arising amidst her aerial glory. Human art can neither colour nor describe so fair a flower. Venus herself feels a rival in the rose, whose beauty is composed of all that is exquisite and graceful.

It has been made the symbol of sentiments as opposite as various. Piety seized it to decorate the temples, whilst Love expressed its tenderness by wreaths, and Jollity revelled adorned with crowns of roses. Grief strews 
it on the tomb, and Luxury spreads it on the couch. It is mingled with our tears, and spread in our gayest walks; in epitaphs it expresses youthful modesty and chastity, whilst in the songs of the Bacchanalians their god is compared to this flower. The beauty of the morning is allegorically represented by this flower, and Aurora is depictured strewing roses before the chariot of Phobus.

"When morning paints the orient skies, Her fingers burn with roseate dyes."

It is thought to have given name to the Holy Land where Solomon sang its praise, as Syria appears to be derived from Suri, a beautiful and delicate species of rose, for which that country has always been famous; and hence called Suristan (the Land of Roses).**

"Each common bush shall Syrian roses wear."

VIRGIL.

" Now, upon Syria's land of roses Softly the light of eve reposes."

T. MOORE.

Forster says, "the rose of Kashmire for its brilliancy and delicacy of odour has long been proverbial in the East."

* Richardson.

L 4 
"Who has not heard of the vale of Cashmere, With its roses the brightest that earth ever gave."

T. Moore.

The oriental poetry abounds in flowery allusions to this plant.

"You may place a hundred handfuls of fragrant herbs and flowers before the nightingale, yet he wishes not, in his constant heart, for more than the sweet breath of his beloved rose." ${ }^{*}$

" Oh! sooner shall the rose of May

Mistake her own sweet nightingale, And to some meaner minstrel's lay

Open her bosom's glowing veil."

T. Moone.

The Ghebers say, that when Abraham, their great prophet, was thrown into the fire by order of Nimrod, the flame turned instantly into " a bed of roses, where the child sweetly reposed." †

According to the Indian mythology, Pagoda Siri, one of the wives of Wistnou, was found in a rose.

The island of Rhodes owes its name to the prodigious quantity of roses with which it abounds.

Ludovico Verthema, who travelled into the East in the year 1503, observes, that Taessa 
was particularly celebrated for roses, and that he saw a great quantity of these flowers at Calicut, both red, white, and yellow ; and Sir William Ouseley tells us, in his work on Persia, that when he entered the flower-garden belonging to the governor of a castle near Fassa, he was overwhelmed with roses. In Persia, wine and other liquors are brought to table with a rose in the bottle instead of a stopple or cork.

Jackson says, that the roses of the Jinan Nile, or garden of the Nile (attached to the Emperor of Morocco's palace), are unequalled, and that mattrasses are made of their petals for the men of rank to recline upon; and we read in Father Catrou's "Histoire du Mogol," that the celebrated Princess Nourmahal caused an entire canal to be filled with rose-water, upon which she took her pleasure with the Great Mogul.

The heat of the sun disengaging the water from the essential oil of the rose, this substance was remarked floating on the surface of the canal; and it was thus that the essence or otto of roses was first discovered.

A perfumer in Paris, who made otto of roses for the court of Louis the Sixteenth, says, it required four thousand pounds weight 
of rose leaves to produce seventeen ounces of the oil.

Of the birth of the rose, it is related in fable, that Flora having found the corpse of a favourite nymph, whose beauty of person was only surpassed by the purity of her heart and chastity of mind, resolved to raise a plant from the precious remains of this daughter of the Dryads, for which purpose she begged the assistance of Venus and the Graces, as well as of all the deities that preside over gardens, to assist in the transformation of the nymph into a flower, that was to be by them proclaimed queen of all the vegetable beauties. The ceremony was attended by the zephyrs, who cleared the atmosphere, in order that Apollo might bless the new-created progeny by his beams. Bacchus supplied rivers of nectar to nourish it, and Vertumnus poured his choicest perfumes over the plant. When the metamorphosis was complete, Pomona strewed her fruit over the young branches, which were then crowned by Flora with a diadem, that had been purposely prepared by the celestials to distinguish this queen of flowers.

Anacreon's birth of the rose stands thus translated by Moore. 
" Oh! whence could such a plant have sprung?

Attend - for thus the tale is sung:

When, humid from the silvery stream,

Venus appear'd, in flushing hues,

Mellow'd by Ocean's briny dews -

When, in the starry courts above,

The pregnant brain of mighty Jove

Disclosed the nymph of azure glance -

The nymph who shakes the martial lance!

Then, then, in strange eventful hour,

The earth produced an infant flower,

Which sprung, with blushing tinctures drest,

And wanton'd o'er its parent's breast.

The gods beheld this brilliant birth,

And hail'd the rose - the boon of earth !

With nectar drops, a ruby tide,

The sweetly-orient buds they dyed,

And bade them bloom, the flowers divine

Of him who sheds the teeming vine:

And bade them, on the spangled thorn

Expand their bosoms to the morn."

Ode 55.

Fabulous authors also account for the delicious perfume of the rose, by telling us that Love, in a feast of Olympus, in the midst of the gaiety of a light and lively dance, overthrew, with a stroke of his wing, a cup of nectar, which precious liquor falling on the rose, embalmed it with that heavenly fragrance which it still retains.

The rose is said to have been originally white, and its change of colour is thus elegantly accounted for by the luxuriant imagination of Catullus. 
" While the enamour'd queen of joy Flies to protect her lovely boy,

On whom the jealous war-god rushes;

She treads upon a thorned rose, And while the wound with crimson flows,

The snowy floweret feels her blood, and blushes!"

Mythological writers also relate that Rhodante, queen of Corinth, to avoid the pursuit of her lovers, fled into the temple of Diana to conceal herself; but being besieged by lovers, and obliged to appear, she called on the people for assistance, who, on beholding her beauty, threw down the statue of Diana, and declared her to be the goddess of the temple; upon which Apollo changed her into a rose.

The first rose ever seen was said to have been given by the god of love to Harpocrates, the god of silence, to engage him not to divulge the amours of his mother Venus; and from hence the ancients made it a symbol of silence, and it became a custom to place a rose above their heads in their banqueting rooms, in order to banish restraint, as nothing there said would be repeated elsewhere; and from this practice originated the saying, "Under the rose," when any thing was to be kept secret.

The Turks are great admirers of this lovely flower, and Mussulmen in general believe, that it first sprang from the perspiration of 
Mahomet, on which account they will not suffer a rose leaf to lie upon the ground, or permit any one to tread upon this sacred flower.

The Greeks named this flower 'Podóv, which, according to some etymologists, is derived from the two words ¿́ǵov and $\delta \dot{\delta} \mu \dot{y}$, on account of the sweet odour which it exhales. 'O $\delta \mu$ ' being derived from the verb $\% \xi \omega$, it is probable that the Latins derived their name for the rose, Rosa, from the Greek $s$ being restored for the zeta instead of delta, and all the modern languages have followed the Latin with but slight deviations.

In the luxurious days of the ancients, even the warriors crowned themselves with garlands of roses, during their principal repast; and Pliny tells us that their delicate meats were either covered with the petals of these fragrant flowers, or sprinkled with its odourous oils. At a feast which Cleopatra gave to Antony, the royal apartments were covered with rose leaves to a considerable depth.

The triumvir, when dying, begged of the captivating queen that she would scatter perfumes on his tomb and cover it with roses.

In Turkey a rose is sculptured on the monument of all ladies that die unmarried; and in Poland they cover the coffins of chil- 
dren with roses, and when the funeral passes the streets, a multitude of these flowers are thrown from the windows. Camden tells us, " There is a classical custom observed, time out of mind, at Oakley, in Surrey, of planting a rose-tree on the graves, especially of the young men and maidens who have lost their lovers; so that this church-yard is full of them." It is the more remarkable, since it was anciently used both amongst the Greeks and Romans ; who were so very religious in it, that we find it often annexed as a codicil to their wills (as appears by an old inscription at Ravenna, and another at Milan), by which they ordered roses to be yearly strewed and planted on their graves. Hence the line of Propertius :

Et tenerâ poneret ossa rosâ;

"And lay his bones in soft roses."

And Anacreon, speaking of it, says, that it protects the dead,

" Preserves the cold, inurned clay, And marks the vestige of decay."

Moore's Anacreon.

This ancient custom of decorating graves with flowers, the symbols of fleeting mortality, has almost passed from recollection in 
this country, and is rapidly disappearing in most parts of Wales; but we read in the "Beauties of England," that Thomas Stevens, a poor and aged man, who lies buried in the church-yard of the village of Stokenchurch, in Oxfordshire, left a request that his eldest son would annually dress his grave with flowers on the recurrence of (the wake) St. Peter's.

It seems now to be a study in this country to make our tombs monuments of oblivion, whilst in Paris they have renewed the ancient custom of planting flowers on the graves of their departed friends, particularly at the cemetery of Père la Chaise. It is impossible to visit this vast sanctuary of the dead, where the rose and the cypress encircle each tomb, or the arbor vitæ and eglantine shade the marble obelisk, without feeling a solemn, yet sweet and soothing emotion steal over the senses as we wander over this variegated scene of hill and dale, columns and temples, interspersed with luxuriant flowering shrubs and fragrant herbs, that seem to defy the most profane hand to pluck them. In these winding paths, where contemplation loves to dwell, we could not forbear reciting these lines of "L'abbé de la Chassagne : 
"Roses, en qui je vois paroître Un éclat si vif et si doux,

Vous mourrez bientôt; mais peut-etre

Dois-je mourir plutôt que rous !

La mort, que mon âme redoute,

Peut m'arriver incessamment.

Vous mourrez en un jour, sans doute, Et moi peut-être en un moment!"

At this instant we found a funeral procession slowly winding towards us, amid the monumental stones, and avenues of trees, to avoid which, we ascended the height, where our attention was attracted by a grave covered with fresh moss, and thickly strewed with the most odorous white flowers, such as the orange-blossom, jasmine, myrtle, and white rose. At each corner stood white porcelain vases, filled with similar flowers, all of pure white; the whole was covered with a fence of wire-work; and the monument was without a name, and had only this simple and pathetic inscription, "Fille chérie - avec toi mes beaux jours sont passés! 5. Juin, 1819."

We were told that the afflicted parent still continued to indulge in the sad duty of replenishing the grave with fresh Howers, at the earliest opening of the gates of this melancholy garden of graves.

The most trivial objects will sometimes make impressions on the mind, even against 
our reason, and it is with difficulty we avoid sensations of affliction, when we now look upon bouquets of colourless flowers, whereas others equally enliven us; but these, too forcibly remind us of the elegant child with whom we can no more tread the consecrated ground of Père la Chaise.

The Mexicans, says the Abbé Clavigero, have from time immemorial studied the cultivation of flowers and odorous plants, which they employ in the worship of their gods; and in the temple of the true God the high priest was formerly crowned with roses. The Catholic church has still preserved the use of these flowers in its most sacred ceremonies, as it is always the rose that they strew before the holy sacrament in solemn processions.

There is now to be seen at Rome, in the church of Saint Susan, an old Mosaic, which represents Charlemagne kneeling, receiving of St. Peter a standard covered with roses. The custom of blessing the rose is still preserved at Rome, and the day is called Dominica in rosâ. They make in that city artificial rose-trees of pure gold, which are blessed by the Pope on the first Sunday in Lent, while they sing Lætare Jerusalema, VOL. II. 
and which after mass he carries in procession; and then sends to sovereigns or presents to princes who visit his capital: and it was the custom until about these last forty years, for the prince who received this rose-tree to give a sum equal to five-humdred pounds to the person who brought him this present from the Pope; but the rosetree by its weight alone was worth twice this sum.

Pope Julius the Second sent a consecrated rose of gold, dipped in chrism, and perfumed with musk, to Archbishop Warham, April 5, 1510, to be presented to Henry the Eighth, at high mass, with the apostolical benediction. The king received the precious rose, and more precious benediction, with profound reverence and excessive joy. But every body knows how soon the remembrance of this rose faded with this capricious monarch.

Mary Stuart, Queen of Scots, sent a magnificent silver rose-tree to Ronsard, the French poet, of the sixteenth century, which was valued at two thousand crowns, with this inscription: Ronsard, l'Apollon de la Source des Muses. As a specimen of his verse we give his ode on the rose.

" Mignonne, allons voir si la rose,

Qui ce matin avoit déclose 
Sa robe de pourpre au soleil, N'a point perdu cette vesprée, Les plis de sa robe pourprée Et son teint au vôtre pareil.

Las! voyez comme un peu d'espace, Mignonne, elle a, dessus la place,

Las! las! ses beautés laissé choir!

Oh! vraiment, marâtre nature, Puisqu' une telle fleur ne dure Que du matin jusques au soir, Donc si vous me croyez, mignonne,

Tandis que votre âge fleuronne En sa plus verte nouveauté, Cueillez, cueillez votre jeunesse; * Comme à cette fleur la vieillesse Fera ternir votre beauté."

Bayle relates an accident which happened at the baptism of Ronsard. In those days it was customary to bring large vases full of rose-water, and baskets of flowers to christenings; and as the nurse was going to church with the infant bard she let her flowers fall, and in turning to recover them, she touched the attendant who carried the vase of rosewater, and spilt it on the child; and this, says Bayle, was since regarded as a happy

* This idea recalls to recollection the lines of Waller:

Song to a Rose.

" Tell her that's young

And shuns to have her graces spy'd,

That hadst thou sprung

In deserts where no men abide,

Thou must have uncommended died." 
presage of the good odour that would some day scatter his poetry.

Painters represent Saint Dorothy holding a nosegay of roses, because it is told in her life that an angel gave her a bunch of roses; and a prodigy is related of Saint Louis, a bishop, who was nephew to Louis the Ninth of France. It is pretended that a rose was seen to come out of his mouth after his death.

In the abbey of Saint Croix, at Poictiers, they show a pillar that was raised to commemorate a pretended miracle, and where they tell you a rose-tree in full blossom sprung out of the grave of a young man, on the day after his interment. It is truly shocking that the teachers of Christianity should countenance such absurd superstitions. We could enumerate many others coupled with the rose; but we are more anxious to give space for an account of the agreeable use to which this flower was put by Saint Médard, who about the year 530, instituted the most affecting prize that piety has ever offered to virtue. It was a crown of roses for that villager's daughter who was the most modest, most obedient to her parents, and the most discreet. The first rose-tree was his own 
sister, whom he crowned in the church of Salency.

We cannot pass over unnoticed the wellknown story of the rose-leaf, which shows how fond the eastern nations were of conveying their thoughts by hieroglyphics.

At Amadan there was a famous academy, the rules of which were, that the members of it should think much, write little, and speak as seldom as possible. Zeb, a learned doctor, celebrated all over the East for his great knowledge, hearing of a vacancy in this institution, hastened to the city in order to be elected. Unfortunately he arrived too late, for the place had already been filled by a candidate, who, like many in these times, owed his success to his power more than to his deserts. The president of the academy filled a vase so full of water that an additional drop would make it run over, by which the doctor was to understand that their society was too full to admit of another member.

The learned Zeb was retiring sorrowfully, when by chance he perceived a petal of a rose at his feet, which he seized with promptness, and placed it so delicately on the top of the water, that it did not disturb the liquid in the least. This ingenious allusion was received by the assembly with the greatest 
approbation, and the academicians testified by their unanimous applause, their consent to the reception of the illustrious $\mathrm{Zeb}$ as a member of their society.

Oriana, when confined a prisoner in a lofty tower, threw a wet rose to her lover to express her grief and love; and in the floral language of the East, the presenting a rosebud with thorns and leaves, is understood to express both fear and hope; and when returned, reversed, it signifies that you must neither entertain fear or hope. If the thorns be taken off before it is returned, then it expresses that you have every thing to hope; but if the leaves be stripped off, it gives the receiver to understand that he has every thing to fear. The pronoun $I$ is understood by inclining the flower to the right, and the pronoun thou by inclining it to the left.

The poet Bonnefons sent to the object of his love a nosegay consisting of a white and a red rose, the one to indicate the paleness of his complexion, caused by anxiety, and the other by its carnation tint, was to express the flames of his heart. The bouquet was accompanied by this verse :

“ Pour toi, Daphné, ces fleurs viennent d'éclore,

Vois, l'une est blanche, et l'autre se colore

D'un vif éclat: l'une peint ma paleur,

L'autre mes feux : toutes deux mon malheur." 
Thus the flower which Philostratus dedicated to Cupid is made to speak the language of love. We are told that some persons have passed through life without feeling the arrows of the young god; and we read of others who could not endure the sight or smell of roses. Mary de Medicis, it is said, detested roses even in paintings, and the Knight of Guise fainted at the sight of a rose. These strange aversions are unnatural, and the objects deserve our pity.

Man alone seems born sensible to the delight of perfumes, and employs them to give energy to his passions, for animals and insects in general shun them. The beetle is said to have such an antipathy to roses, that the odour of this flower will cause its death ; from which the ancients devised the allegory, to describe a man enervated by luxury, by representing him under the image of a beetle expiring surrounded by roses.

Madame de Genlis tells us that formerly the rose was considered so precious in France that in several parts of that country the inhabitants were not allowed to cultivate it, as if all but the powerful were unworthy of such a gift; and at other times we find it mentioned among the ancient rights of manors, to levy a tax or tribute of so many bushels of 
roses, for the provision of rose-water for their lord, whose table was also covered with roseleaves instead of napkins. The French parliament had formerly a great day of ceremony, called baillée de roses, because great quantities of roses were then distributed.

We presume that it was formerly more customary to use rose-water in this country than at present, as we find amongst the charges in the account of a dinner of Lord Leiyster, Chancellor of the University of Oxford, Sept. 5. 1570 : "For iij oz. of rosewatere, for boylde meats, and leaches, and gelleys, and drie leches, and marche payne, and to wash afore dimnere, and after dinnere, iij s. ix d."

Rose-water is still in such demand in Damascus, for the purposes of cookery, that many hogsheads of it are sold daily in the markets of that city.

As we now possess upwards of eight hundred different kinds of roses, it would be in vain to attempt the description of all the varieties and sub-varieties, which nothing short of the most minute inspection can discover, and the nicest pencil pourtray. To such of our readers as may wish to see the roses pictured, we recommend them to inspect the work which Miss Lawrence has published 
in this country, and Les Roses, par Redouté, published at Paris, in three folio volumes.

Of the roses which are natives of these islands, the British Botanist of 1820 notices twenty belonging to England, four to Scotland, one to Ireland, and one to the Scilly islands. These are made to form seven distinct species in the Hortus Kewensis, the most delightful of which is the sweet-brier, or eglantine, rosa rubiginosa or eglanteria.

" By sweet-brier hedges, bath'd in dew,

Let me my wholesome path pursue."

WARTON.

"Come, gentle air! and while the thickets bloom,

Convey the jasmin's breath divine,

Convey the woodbine's rich perfume,

Nor spare the sweet-leaved eglantine." SuEnstone.

It is noticed by Chaucer, as long back as the middle of the fourteenth century,-

"The grene herber

With sycamore was set, and eglatere."

This species of rose is found in chalky or gravelly soil, on heaths, or hedges, in most parts of Europe; but the size and fragrance of the leaf is greatly improved by cultivation, that has also produced six varieties of this fragrant-leaved brier, the most beautiful of which are the double-flowered and 
the double moss brier. It is hardly possible to scatter this shrub too thickly in the plantation, and when we pass hedges of this odorous thorny plant, after a spring shower, we feel not only delighted but refreshed by the fragrance.

The name of Eglantine, by which the sweetleaved brier is known, is taken from the French eglantier. That we so often find French names given to our native plants is not singular, as after the Conquest, French became the written language of this country for many centuries. The Greeks called all the wild roses or briers Kuvópodov, because the root was thought to cure the bite of a mad dog; and the Latins, for the same reason, named them Canina, and from them we call one of our hedge briers the Dog-rose.

It is the dog-rose, rosa canina, that decorates our hedgerows with its tall arching branches and lively odorous flowers in the months of June and July. From the petals of this blushcoloured wild rose, a perfumed water may be distilled, which is thought to be more fragrant than that from garden roses. The leaves of this brier, when dried and infused in boiling water, are often used as a substitute for tea, and have a grateful smell and sub-astringent taste.

The fruit of this brier also forms one of the 
greatest beauties amongst the autumnal tints, being of a bright scarlet, perfectly smooth and glossy, and of an elegant oblong shape. This brier is often called the Hip-tree, from the name of the fruit.

"Still hungering, pennyless, and far from home, I fed on scarlet hips and stony haws.

Hard fare ! but such as boyish appetite Disdains not."

Cowper.

Many persons eat this fruit with pleasure when mellowed by the frost. It was formerly much used as a conserve, the seeds being taken out, and the pulp beaten up with sugar. Gerard says, "The fruit, when it is ripe, maketh most pleasant meates and banketting dishes, as tartes, and such like." The fruit of the rose is nothing more than a fleshy urceolate calyx, from whence the stigma springs, and it afterwards becomes the repository of the true fruit or seed, after the manner of the fig, excepting that the seeds of the hip are divided by silky bristles, or prickly fibres, which cause great irritation on the primæ viæ, if eaten.

It is the strong shoots of this species of rose-tree that the largest kinds of garden roses are now grafted on; and by this means we see, instead of bushes, tall stems throwing out a 
head in imitation of the forest trees. Where it is desirable to raise them to a height above dwarf bushes, it has a good effect; as also when planted in flower gardens, as pinks and other flowers, may cover the ground with blossoms, whilst the rose forms a kind of parasol over them; but in general we prefer a rosebush to a tree of roses, and are better pleased to look into a rose than up to it. Delille notices this modern practice with that of keeping apple-trees in a dwarf state.

" Of old, the rose on lowly bramble sprung, While high in air the ruddy apple hung!

Now, strange reverse! the rose-tree climbs the skies, While scarce from earth our apple-trees arise."

The white field rose, rosa arvensis, is commonly called the White Dog-rose. This is much less fragrant than the last-mentioned. As the fruit of this kind ripens, it changes from an oblong into a globose shape. The styles of the flower, as soon as they have passed through the neck of the calyx, are compacted into a cylinder, resembling a single style, terminated by a knob composed of the stigmas, which distinguish it from the other species. It is said to be the most common rose in the west of Yorkshire, and it is generally mentioned as the rebel rose.

A young English lady appearing in com- 
pany at Paris with a sprig of orange flowers in her bosom, was thus complimented by a Frenchman for the clearness of her complexion, at the same time that he gave her a delicate hint that her bosom was more exposed than modesty allowed.

s6 Lovely Tory, why the jest, Of wearing orange in thy breast? Since this breast so clearly shows The whiteness of the rebel rose."

That both the white and the red rose were formerly considered rebellious emblems, the blood of our ancestors has fully proved.

"6 And here I prophesy. - This brawl to-day Grown to this faction, in the Temple Garden, Shall send, between the red rose and the white, A thousand souls to death and deadly night."

Shakspeare.

The idea of taking a red or a white rose, as an ensign for the parties who caused such dreadful devastation in this country for many ages, seems to have originated in the 'Iemple Gardens of London, if we may trust to poetical history, that says in King Henry the Sixth,

"Within the Temple Hall we were too loud; The garden here is more convenient."

In this scene Richard Plantagenet, Duke of York, is made to say, 
"Since you are tongue-ty'd, and so loath to speak, In dumb significants proclaim your thoughts;

Let him, that is a true born gentleman, And stands upon the honour of his birth, If he supposes that I have pleaded truth, From off this briar, pluck a white rose with me."

\section{To which Somerset answers,}

" Let lim that is no coward, nor, no flatterer, But dare maintain the party of the truth, Pluck a red rose from off this thorn with me.

Warroick. I love no colours, and, without all colour Of base insinuating flattery, I pluck this white rose, with Plantagenet. Suffolk. I pluck this red rose with young Somerset, And say withal, I think he held the right.

Vernon. Stay, lords, and gentlemen; and pluck no more, Till you conclude - that he, upon whose side The fewest roses are cropp'd from the tree, Shall yield the other in the right opinion."

\section{This being settled, Vernon says,}

"Then, for the truth and plainness of the case, I pluck this pale and maiden blosson here, Giving my verdict on the white rose side.

Som. Prick not your fingers as you pluck it off;

Lest, bleeding, you do paint the white rose red, And fall on my side so against your will.

Plan. Now, Somerset, where is your argument? Som. Here, in my scabbard; meditating that,

Shall die your white rose in a bloody red. Plan. Now, by this maiden blossom in my hand, I scorn thee and thy fashion, peevish boy."

From that time 1454, until the families were united in 1485 , civil war laid waste the fairest portions of our country, and the sons 
of one father often engaged in battle, and sometimes the father against the son, under the different banners of the red or the white rose.

Whom in this conflict I unawares have kill'd,

O heavy times, begetting stich events!"

"Is this our foeman's face,

Ah, no, no, no, it is mine only son ! -

Ah, boy, if any life be left in thee,

Throw up thine eye; see, see, what showers arise,

Blown with the windy tempest of my heart,

Upon thy wounds, that kill mine eye and heart.-

$\mathrm{O}$, pity, God, this miserable age! -

What stratagems, how fell, how butcherly,

Erroneous, mutinous, and unnatural,

This deadly quarrel daily doth beget! -

$\mathrm{O}$ boy, thy father gave thee life too soon, And hath bereft thee of thy life too late."

In times of terror, fear and superstition are generally seen hand in hand. During these ages of domestic wars, we are told that they discovered a rose-tree at Longleat, which bore white flowers on one side and red ones on the other side, prognosticating both the division and uniting of the two families.

" But oh! how alter'd was the mournful tone, When Harry Richmond, arm'd with title true, His baldrick 'cross his shoulders flung, And with enliv'ning trumpet, blew

A call to arms, that thro' the island rang!

His claim announcing to the English throne."

Dibdin. 
It was, as is pretended, upon the marriage of Henry the Seventh, to Elizabeth, the daughter of Edward the Fourth, that the rose first appeared with mixed petals of red and white, which is still acknowledged throughout Europe, as the emblem of that happy union, by the name of "York and Lancaster Rose."

Having just met with some verses on the white rose, entitled the " Lament of the Year 1745," we give them as being connected with the contending houses, and not as our party spirit, for we may safely say, as the Earl of Warwick did to John Beaufort, Duke of Somerset,

" Between two girls, which hath the merriest eye, I have, perhaps, some shallow spirit of judgement, But in these nice sharp quillets of the law,

Good faith, I am no wiser than a daw."

"Oh, thou pale, snowy rosebud, though rent and laid low

By the rude hand of power in the day of despair, Yet thou still in the breasts of the loyal shalt blow,

Full as lovely, as fragrant, as fresh, and as fair.

Though our bosoms no longer may glow with the dream

Of royalty righted, and exiles restored,

Yet still they may swell with the rapturous theme

Of the faith they long cherish'd, the prince they adored; And still they in silence may weep o'er the woes, Endured by the chieftains who bore the white rose. 
With that deep thrilling interest, where pleasure and poin Contend in the bosom and struggle for sway,

We muse on the emblem of loyalty vain,

And sigh o'er its fill on Culloden's dark day:

Yet the cloud that o'ershadowed the dawning so bright, And obscured with its darkness the valley and heath, With the beam of the meteor flashed radiance and light, And illumed with its splendour the pale field of death, And bright o'er the fallen its lustre arose, And hallowed their sufferings, their valour and woes.

Oh, still whilst our bosoms shall glow with the flame,

Which heaven itself in its mercy inspired, Shall awaken each thrill as it dwells on the fame

Of the heroes so loyal, devoted, admired. And still the loved emblems of loyalty true,

Shall honoured and blest in our bosoms remain, And whilst its white blossoms we pensively view,

We behold no dishonour, or sully, or stain; And ages to come shall admiring disclose, The virtues and fame of the pure snowy rose."

New Monthly.

Gerard tells us, that the double white rose formerly grew wild in the hedges of Lancashire, in great abundance, as briers. This we presume was the white dog-rose, which had become double by some accidental circumstance, and that the variety propagated itself by suckers and layers, in a soil which was suitable for that purpose.

" The sweetest rose where all are roses."

The most delightful rose of which the garden boasts is the Provence or provins rose,

VOL. II. 
rosa provincialis, and which has been claimed by the inhabitants of the south of France as a native of Provence, whilst the Dutch, says Gerard, consider themselves entitled to this flower, and say, as it first came out of Holland it ought to have been named the Holland rose, and not Provence rose; but it appears very evidently from Pliny, that neither of these countries can justly hold it as a native plant. He calls it a Greek rose, and thus describes it in the fourth chapter of his twentyfirst book, "The rose named Grcecula has its petals or flower leaves folded or lapped over each other so closely, that they will not open of themselves, unless they be forced with the fingers, and therefore always look as if they were in the bud, but when they are expanded they are the largest of all the roses." This account correctly corresponds with the nature of the Provence rose, which is often called the Cabbage rose, from the manner in which the petals cabbage or fold over each other. As this rose is so nearly allied to the damask rose, it is probable that the Greeks first obtained it from the vicinity of Damascus, and that the trivial change is owing to soil and cultivation. At what period this beautiful flower first found its way into English gardens is uncertain. Gerard speaks of it as no 
rarity in 1597. Hakluyt says, that the damask rose was brought in by Dr. Linaker, physician to King Henry the Seventh and his successor. But from the verses of Chaucer and other old poets, it appears that the garden roses were common in this country at a much earlier period, and we can hardly suppose that so many pilgrimages would be made to Rome and even to Jerusalem, without some one's bringing back plants of these flowers, that were then so commonly used in Christian churches, and so highly extolled for their medical virtues.

In those early days the principal gardens of this kingdom were attached to priories and other religious houses, and as the heads of these establishments had frequent communication with similar communities on the continent, we may safely conclude that so precious a gift as the rose would not pass neglected. From the luxurious manner in which the Romans lived in this country for many ages, and from their habit of wearing wreaths of roses at their banquets, it is more than probable that they introduced many kinds of their own roses into the gardens which they formed in this island. The principal varieties of the Provence rose are, the Common, Scarlet, Blush, White, Rose de Meaux, 
Pompone, Rose de Rheims, Childing's, Blanford, Rose St. Francis, Shailer's ; and the varieties of the Damask rose are, the Red, Blush, York and Lancaster, Red monthly, White monthly, Blush monthly, Great Royal, Blush Belgic, Red Belgic, Goliath, and Imperial blush, with many others that are yearly raised in various parts of the world by sowing the seeds.

THE MOSS ROSE. - Muscosa.

"The rose that hails the morning,

Array'd in all its sweets,

Its mossy couch adorning,

The sun enamour'd meets."

Tris elegant rose is generally supposed to be the offspring of the Provence rose, whilst others think it belongs to the family of centifolia, or hundred-leaved rose. It appears to have been quite unknown to the ancients, as they have left no description of a flower that resembles it, and it is too singularly beautiful to have escaped Pliny's notice, had it then been in existence. By Furber's catalogue it appears that it was cultivated here in 1724; but Miller first saw it in Dr. Boerhaave's 
garden in Leyden, in 1727. The learned Doctor not only corresponded with many botanical persons in this country, but visited England, and became a member of the Royal Society of London. It is therefore most likely that on its first appearance in this country, a plant would be forwarded to Leyden, for the inspection of a person that all Europe was then regarding as the star of the age.

Although the moss rose appears to be a plant of so short an existence, its birth-place is not satisfactorily known; but from all the accounts we can collect of its register, it appears to be a fortuitous child of England, as we have numerous accounts of its having been exported, but none of its importation into this island, nor has it been discovered elsewhere, excepting in a state of cultivation. Messrs. Lee and Kennedy, of Hammersmith, have within these last few years produced a perfectly single moss rose, which they pronounce to be only a variety of the common Provins rose. We must therefore conclude that the moss-like pubescence on the calyx and young branches, is owing to some accidental circumstance which this climate produces, as we are told that this variety loses its . mossiness, almost immediately when 
planted in Italy, and we have not yet heard of this rose having been in any instance raised from seed, for the single moss rose was reduced to that state from the double variety (either accidentally or intentionally) by a peculiar mode of cultivation. The single variety of the moss rose, as well as the double white moss rose, still continue scarce, and bring high prices to the nurserymen near London.

The moss rose is made the emblem of voluptuous love, and the creative imagination of the poet thus pleasingly accounts for this rose having clad itself in a mossy garment.

"The angel of the flowers, one day,

Beneath a rose-tree sleeping lay.

That spirit - to whose charge is given

To bathe young buds in dews from heavert.

Awaking from his light repose,

The angel whisper'd to the rose, -

' $O$ fondest object of my care,

Still fairest found where all are fair,

For the sweet shade thou'st given to me,

Ask what thou wilt, 'tis granted thee.'

'Then,' said the rose, ' with deepened glow,

' On me another grace bestow.'

The spirit paused in silent thought,

What grace was there that flower had not?

'Twas but a moment - o'er the rose

A veil of moss the angel throws.

And, robed in nature's simplest weed, Can there a flower that rose exceed ?"

M. Redouté, the author of a French pictured work on roses, seems displeased at our 
claiming the moss rose as originating in England: he says, " nous ferons observer qu'il n'est pas rare de voir les Iconographes Anglais considérer beaucoup de plantes comme indigènes au sol de leur pays, toutes les fois que le lieu dans lequel elles végètent naturellement leur est inconnu, circonstance qui doit faire rejeter toutes les assertions de ce genre."

Madame de Genlis tells us, that during her first visit to England, she saw moss roses for the first time, and that she took to Paris a moss rose-tree, which was the first that had been seen in that city; and she says, in 1810 , "the cultivation of this superb flower is not yet known in France."

Madame de Latour endeavours to do away this statement. In a high strain of compliment, she says, "when Madame de Genlis returned from London to Paris, she was become very celebrated, and the crowds of people who went to her house under pretence of seeing the moss rose-tree, were attracted thither by that lady's celebrity; and the modesty of Madame de Genlis alone could have led her into this error ; for this rosetree," she adds, "which is originally from Provence, has been known to us for several ages." 
M. Rossig, who has lately published a work on roses, with good coloured figures, says, that the moss rose is found on the Alps. But this information comes rather late, as it is improbable that a plant of such a size and singular beauty should have escaped the penetrating eyes of the various botanists who have herbalised so frequently on these mountains, as not to have left a species of grass or even moss unrecorded.

The moss rose is propagated by layers or suckers, which it sends up plentifully when growing in rich light garden mould, that is rather moist than over dry. When the branches are laid down they should be slightly bent so as to crack the bark, which will cause them to take root sooner. This beautiful rose is also increased by budding upon stocks of the other sorts, which is generally performed in the month of May; but these plants are not so durable as those raised by layers.

\section{THE HUNDRED-LEAVED ROSE. - Rosa Centifolia.}

THIs is the rose with which painters chuse to represent Love and Hymen. It is certainly a 
fine flower, being very double and of a deep crimson colour; but the perfume is very weak, and the petals do not hang so loose and gracefully as in many other species; and it has, from the regularity of its petals, been compared to a rose made by a turner, and therefore called Flos quasi tornatus.

This species of rose, which has become the parent of a most numerous variety, is a native of the mountains lying between 41 and 42 degrees north latitude, if we may trust to the best ancient natural historians that ever wrote on plants. Pliny says, in book xxi. chap. 4 . that the roses which grow about Campania, in Italy, and near Philippi, a city in Greece, are so double that they have a hundred leaves, and are therefore called Centifolia. "However," says this author, "these soils do not bring forth these hundred-leaved roses naturally, for it is the mountain Pangæus near adjoining upon which they grow naturally, but when transplanted into the neighbourhood of Philippi they become finer flowers than when on their native mountain ;" and he adds, that "these very double roses are not.so sweet as others." This author tells us, that Cæpio, who lived in the time of the emperor Tiberius, was of opinion, that the hundred-leaved rose had no grace in a gar- 
land either for smell or beauty, and therefore should not be used in chaplets. Loureiro mentions it as a native of China; but Theophrastus and Pliny clearly prove it to be an European tree.

Aiton does not notice the native place of this rose; and it is also omitted in Le Bon Jardinier of Paris, down to the present time. The able compiler of the Hortus Kewensis, tells us, from Gerard, that it was cultivated in our gardens in 1596. This appears to be an error, as Gerard in the original edition only notices this rose from the writings of the ancients ; Martyn has fallen into the same mistake, in his admirable edition of Miller.

We are not therefore able to discover at what time this rose was introduced, as it is not noticed by Parkinson, in his "Garden of Pleasant Flowers," of 1629 ; nor does it appear in his " Theatre of Plants," of 1640.

The principal varieties of this rose we give from the Kew catalogue, which are the Dutch Blush, Singleton's, Burgundy, Single Velvet, Double Velvet, Sultan, Stepney, Lisbon, Bishop, Cardinal, Blush Royal, Petit, Pluto, Monstrous, Fringe, Plicate, Two-coloured, and Shell. 
THE CINNAMON or MAY ROSE. - Rosa Cinnamoma.

"Ton frais bouton, d'une aimable couleur,

Du cinnamome exhale l'ambroisie:

Et Flore en toi, par une douce erreur,

Croit respirer les parfums de l'Asie."

Tris agreeably perfumed rose, which opens its small blossoms in our gardens about the end of May, is a native of Nice in Italy, and has been common in our pleasure-grounds for many ages, as Gerard tells us, in 1597, that it was then cultivated in this country, both in its single and double state. This rose loves a dry soil and sunny situation, and deserves a more frequent place in the shrubbery than modern plantation allows it, as its flowers appear a month before the common roses, and the bush grows tall enough to fill a middle situation amongst shrubs, where its smooth plum-coloured branches have a good effect. It is a favourite with our fair, as it may be worn in the bosom longer than any other rose, without fading, whilst its diminutive size, and red colour, together with a pleasant perfume, adapt it well to fill the place of a jeweller's broach. 
THE MUSK ROSE._Rosa Moschata.

" And each inconstant breeze that blows, Steals essence from the musky rose."

THIs species of rose owes its name to the fine musky odour which its numerous white blossoms exhale during the autumnal months. It is a native of Barbary, and grows wild in the hedges and thickets in the kingdom of Tunis; and the Tunisians cultivate it also for the sake of a highly odorous essential oil, which they obtain from the petals by distillation.

This rose has been found growing naturally in Spain by Robert More, Esq., who sent seeds to this country. We presume it was first planted in Spain, when the Moors overran the coast of that country.

Hakluyt tells us, in 1582, that we first obtained the musk rose from Italy. It was cultivated commonly in the time of Gerard, and as it sends forth large umbel bunches of flowers at the end of each branch, in the months of September and October, it forms an agreeable companion to the common China rose, which blossoms also plentifully at that season. 
The stalks of the musk rose are often too weak to support the large bunches of flowers that crown its branches. It therefore requires a support to keep them from the earth, unless it be planted with dwarf evergreens, that form a natural and beautiful prop to these delicate blossoms.

THE YELLOW ROSE. - Lutea and Sulphirea.

The single yellow brier rose, luica, is said to be a native of Germany, the south of France, and Italy; and the single orange-coloured rose, bicolor, is an Austrian rose.

That it was through these countries we first became acquainted with the yellow rose, there can be no hesitation in stating; but that they were originally brought from more eastern climates, seems equally çertain, since no ancient author that we have consulted, mentions a yellow rose of any description; and, had it been a flower created by the art of grafting, as was formerly imagined, we should, ere this, have discovered the fact. Ludovico Verthema tells us, in 1503, that he saw great quantities of yellow roses at Calicut, from whence we have no doubt, both the sin- 
gle and double varieties were brought into Europe by the Turks, as Parkinson tells us in a work which he dedicated to Henrietta, the queen of our unfortunate Charles the First, that the double yellow rose "was first procured to be brought into England, by Master Nicholas Lete, a worthy merchant of London, and a great lover of flowers, from Constantinople, which (as we hear) was first brought thither from Syria, but perished quickly both with him, and to all other to whom he imparted it: yet, afterwards it was sent to Master John de Franqueville, a merchant also of London, and a great lover of all rare plants, as well as flowers, from which is sprung the greatest store, that is now flourishing in this kingdom."

The double yellow rose, sulphurea, was unknown to us in 1597 ; but the single yellow brier was then common, as we find by Gerard.

The single yellow rose, lutea, blossoms freely in most situations, excepting in the vicinity of London, or other confined spots.

The double yellow rose, where it blossoms freely, is one of the most elegant flowers that any country has produced, and had nature bestowed on it the perfume that makes the Provence rose so delightful, it would be pronounced the acme of Flora's skill. 
The outer petals are of the most delicate golden yellow, whilst the inner ones are often of a tint approaching to copper colour, and so delicately thin and transparent, as even to surpass the carnation poppy in texture; and although the flower is exceedingly double, yet the petals hang with a looseness and elegance that scarcely can be conceived without beholding it. Van Os the elder has been the most happy amongst painters in giving that transparent and crumpled effect to this rose, which Van Huysum himself could never so perfectly accomplish. Sydenham Edwards has left a faithful representation of the double yellow rose, which is given in the 46th page of the Botanical Register.

We remember this species of rose much more common than at present, growing in open situations, and we have generally observed that it has prospered best in an eastern aspect, where buildings or shrubs have sheltered it from the midday sun. It loves a light soil, of a gravelly or sandy nature, but cannot endure confined or wet situations. We have seen it in great perfection in a garden at Petersfield, in Hampshire; and it prospers and flowers fieely in some parts of the South Downs, particularly at Findon, in Sussex. It seems much less affected by the 
cold than by low and damp situations; and we do not recollect having met with it in flower except in spots open to the east, which generally is considered the most pernicious to plants. The foliage of the double yellow rose is small, and of a beautiful bluish green, very light on the under side, whilst the stalks being of a delicate yellow-green, form a delightful graduation to the golden flower.

THE EVER-BLOWING CHINA ROSE. Semperfiorens.

WIIEN this species of rose was first introduced, in 1789, it was considered to be so delicate a plant, that it was kept constantly in the stove, and the smallest cuttings were sold for many guineas each. It was soon found to thrive in a common green-house, where it blossomed the whole winter, to the great admiration and no small amazement of all who could obtain sight of this far-fetched flower. As it was found to be of so easy a propagation, in a few years every country casement had the pride of sheltering this Chinese prodigy, until the cottager, for want of pence to purchase flowerpots, planted it in the open ground; when, 
as if it gloried to breathe in the air of this land of liberty, it soon surpassed in strength and beauty all the inmates of the "gardens, in which art supplies the fervour and the force of Indian skies."

We have no plant upon record, either of utility or beauty, that has spread itself so rapidly over the whole country as this rose has done in our own age. It now climbs up to look into the attic windows of the very houses where we once saw it peep out of the lower casement; and it is not uncommon to see its petals blush through a veil of snow in the month of December; a thing so unusual formerly, that no longer back than the year 1800, Mrs. Mary Robinson wrote the following verses on seeing a rose in flower at a cottage door on Egham-hill, on the 25th of October of that year.

"Why dost thou linger still, sweet flower?

Why yet remain, thy leaves to flaunt?

This is for thee no fostering hour -

The cold wind blows,

And many a chilling, ruthless shower, Will now assail thee, beauteous rose!"

Although it is acknowledged that few plants contribute more agreeably to ornament our shrubbery in the autumnal months than this Chinese rose, yet we would not

VOL. II. 
wish it to exclude or lessen the cultivation of the older and more beautiful species, but which, we fear, it has already done to a considerable degree. As the smallest cuttings of this rose will grow, we are not without the hope of seeing it creep into our hedgerows, where it would soon propagate itself both by suckers and seed; for it ripens its fruit in this climate as perfectly as those of our native briers, and the hips of the Chinese rose are particularly ornamental, from their inverted pear shape, fine orange colour, and large size.

The deep-red Clina rose was first introduced by Gilbert Slater, Esq. of Knotsgreen, near Laytonstone, in the year 1789; but this is still confined to the greenhouse, being of a much more delicate nature than the common China rose. The flowers are semi-double, and large in proportion to the plant, of a fine dark carmine colour, and of a delightful fragrance.

The China rose, which has been named Lady Banks's Rose, rosa Banksia, we hope to see soon hardy enough to leave the greenhouse, where it has occupied a place since the year 1807. This is a double-white rose, of very diminutive size, but producing such abundance of blossoms, as to render the branches extremely elegant. We are in- 
formed that it was discovered growing out of an old wall in China.

In pleasure-grounds it is scarcely possible to plant too many rose-trees, and they have the best effect when three or four plants of the same kind stand together. The Scotch or burnet-leaved rose, from its dwarf growth, forms a good foreground to other roses; and the neat little Rose de Meaux should advance towards the walks, whilst the more towering kinds may mix with shrubs of the middle class.

Where the lawn is interspersed with little clumps, fenced with basket-work, each clump or basket should be confined to one species of rose, or kinds that are quite opposite in colour; and as it is particularly desirable to keep these clumps successively in blossom during the season, those clumps which blossom the earliest and the latest should be divided by others that flower in the intermediate space.

Rosaries are formed in various devices; but the most common method is by planting the tallest standard rose-trees in the centre of a clump, around which the different species and varieties are placed according to their height of growth, the edge finishing by the dwarf kinds.

Rock work is sometimes covered with 
creeping roses, and surrounded with other varieties.

For covering arbours or trellis-work, the bracted rose, Rosa bracteata, commonly called Sir George Staunton's rose, which was brought from China in the year 1795, is the most proper, as it grows to a great height, and thick of branches that are covered with shining leaves of a very fine green. The flowers are single and perfectly white, of a strong and agreeable perfume: it blossoms in August and September.

The modes of retarding the flowering of the Provence and moss-roses, until the autumn are various; and as it is desirable to continue these beauties of the garden longer than they are naturally disposed to last, we shall mention the best means of obtaining this enjoyment. The most simple method is by cutting off all the tops of the shoots that have been produced the same spring, which should be done just before they begin to show their buds; this will cause them to make fresh shoots, that will produce flowers late in the autumn. It may also be done by transplanting the bushes in the spring, just as they have formed their buds, which should be cut off, but the roots must not be out of the earth long enough to become dry, and they gene- 
rally require watering when transplanted late, to obtain roses in October and November. On the continent, where much more pains are bestowed on the retarding of flowers than in this country, the rose-trees are dug up just as they begin to shew a leaf-bud, and the roots are instantly placed in a kind of mortar, formed of brick earth, which serves as a preservative plaster, whilst it debars the fibres of the roots from obtaining the necessary nutriment that would cause the usual growth of the plant. From this state of rest, the plants are removed into the clumps or flower borders in May or June, according to the time they are wished to be in blossom. When the season is dry, they will require frequent watering to ensure fine flowers. These plants should be kept in a cellar or a shed, where there is but little light.

The common Provence and moss-roses are the most esteemed for forcing, on account of their perfume.

“ "This soft family, to cares unknown, Were born for pleasure and delight alone. Gay without toil, and lovely without art, They spring to cheer the sense and glad the heart."

Mrs. Barbauld.

Yet this sweet emblem of love, like the 
human body, breeds a canker in its bosom, that often destroys its heart.

"She never told her love,

But let concealment, like a worm i'the bud, Prey on her damask cheek."

ShaKspeare.

"Death's subtle seed within,

(Sly, treacherous miner !) working in the dark,

The worm to riot on that rose so red,

Unfaded, ere it fell ; one moment's prey !"

YounG.

The principal enemy of the rose is a species of fly, called the rose Saw-fly, Tenthredo rosea, which pierces the tender flower-bud, and thrusts an egg into the puncture, which soon becomes a caterpillar, that nourishes itself by eating away the heart of the young flower and fruit down to where it joins the stalk. It then loses its supply of nourishment, droops to one side and dies, whilst the insect spins itself a descending rope, by which it reaches the ground, and there entombs its body in a silken shell, whilst its transformation takes place first into a chrysalis, and then a fly, which renews this work of devastation. There are several flies of this genus, that are all equally injurious to the rose-tree. These flies are furnished with a very remarkable instrument, in the shape of a saw, by which they make small holes in the 
bark of the young branches, where they deposit their numerous eggs, which on the succeeding summer are hatched by the warmth of the sun, and nourished by the ascending sap, until they assume the appearance of small green flies, in which state they issue from the bark in such numbers as to cover the tender shoots and leaves, on which they rest, to suck the nutriment of the plant. These flies may be known by a yellow body and black head, with four wings edged with black, and yellow legs spotted with black. Another species of rose-fly has a head and breast of violet colour, with a body of yellow; and legs and wings of pale violet. It may be seen in a summer's morning working on the branches of the rose-tree, and from its sluggish nature will suffer itself to be taken between the fingers. The branches where it has deposited its eggs are so vitiated by it, that they are easily discovered, as they generally swell to a greater size than the parts above or below, and they often become black on the under side: when examined with a glass, the eggs may be discovered. These branches should be carefully cut off; and when the plants are covered with these insects, it is desirable to brush them off with a bunch of feathers or young elder branches, as 
they fix themselves too fast to be washed off by water.

Insects may be destroyed by placing a chafing dish, with lighted charcoal under the bushes, and then throwing a little brimstone on the coals; but this must be done in small quantities, and carefully, lest the sulphur injure the plants.

The lady-bird, coccinella punctata, so named from the points or specks on its shell wings, hunts rose bushes to feed on the small insects vulgarly called blights.

The brier and Scotch roses are frequently attacked by the Cynips rosa, which, by puncturing the bark, occasions the production of those singular and beautiful flossy tufts, which are so frequently seen on wild roses. 'These rose galls contain several little cavities, in each of which is a small maggot. This substance was formerly used in medicine, under the name of Bedeguar.

The rose is too important a flower to have been overlooked by Asculapius, who in old times used every part of this plant, from the root to the yellow anthers within the blossom, for some particular purpose in medicine, as may be seen in the works of all the ancient medical authors. The kinds of roses principally used in modern practice, are the red and 
the damask. The latter is considered a safe and gentle purgative for children, when administered in infusion or by way of syrup.

The red roses are astringent, and particularly so when taken before they are fully blown; conserves are made of both these kinds of roses.

Ladies may make their own milk of roses, by simply adding one ounce of the oil of almonds to a pint of rose water, after which ten drops of the oil of tartar is to be added.

We shall conclude our history of the rose with the lines of the Ayrshire Ploughman.

" Never may'st thou, lovely flower,

Chilly shrink in sleety show'r!

Never Boreas' hoary path,

Never Eurus' pois'nous breath,

Never baleful stellar lights,

Taint thee with untimely blights !

Never, never, reptile thief,

Riot on thy virgin leaf!

Nor even Sol too fiercely view

Thy bosom blushing still with dew!

May'st thou long, sweet crimson gem,

Richly deck thy native stem;

Till some ev'ning, sober, calm,

Dropping dews, and breathing balm,

While all around the woodland rings,

And ev'ry bird thy requiem sings;

Thou, amid the dirgeful sound,

Shed thy dying honours round,

And resign to parent earth

The loveliest form she e'er gave birth." 


\section{RHODODENDRON.-RHODODENDRON.}

Natural order, Bicornes; Rhododendra, Juss. A genus of the Decandria Monogynia class.

" O'er pine-clad hills, and dusky plains, In silent state Rhodonia reigns, And spreads, in beauty's softest blooms, Her purple glories through the glooms." SHaw.

The Greeks named this flowering shrub Pododevdpov, Rhododendron, from podov, a rose, and $\delta \varepsilon \nu \delta \rho o v$, a tree. It was also called in that language Rhododaphne, the rose laurel. Pliny observes, that this plant was not so happy as to have a name given it by the Latins, and it is somewhat remarkable, that it should retain to this day the original name throughout Europe.

The foliage of this shrub is a poison to horses, asses, mules, sheep, and goats, \&c.; yet it was anciently esteemed one of the best counter-poisons to man, particularly against the venom of serpents.

Tournefort tells us that there is a kind of rhododendron about 'Trebizond, whose flowers 
the bee feeds upon, and the honey thence obtained drives those mad that eat of it.

"Ev'n as those bees of Trebizond, -

Which from the sunniest flowers that glad With their pure smile the garden round,

Draw venom forth that drives men mad!"

T. Moore。

The upper segment of the flowers of this plant performs the office of nectary. It is grooved in the middle, and is so fertile in the formation of honey, that you may observe a sweet globule in almost every expanded flower. There are in this part spots of a dingy purple, that indicate poison, and so well were the Romans acquainted with the poisonous nature of this honey, that they would not receive the Pontic honey in tribute, but obliged the unfortunate inhabitants of that neighbourhood to pay them a double portion of wax in lieu of it.

Dr. Turner, who wrote on this plant about the year 1568, says, "I have sene thys tre in diverse places of Italy, but I care not if it neuer com into England, seyng it in all poyntes is lyke a pharesey, that is beauteus without, and within a rauenus wolf and murderer."

Notwithstanding this appalling character, the Pontic rhododendron found its way into 
the British shrubbery in the year 1763, where it still continues to display its clusters of fine purple blossoms, during the months of May and June, to the delight of all the lovers of flowering shrubs. In the royal gardens at Kew there are groves of these plants, which, when in full flower, present a mass of purple beauties that are splendid beyond description.

The original birth-place of this shrub is thought to have been in the southern subalpine tracts of Caucasus, where it still abounds in wet places, particularly in beech and alder woods; but it is not now confined to the neighbourhood of the Black sea, as it has extended itself to many places of the Levant, and reached even to Gibraltar. A variety of this or a similar species of rhododendron is also distributed over a great part of Siberia, and has been observed through the deserts of Mogul Tartary, to China and Thibet. It grows very commonly in the pine forests; and in some parts in such profusion and so densely as to make whole tracts appear a sheet of purple in April and May. This species was introduced from Russia, by $\mathrm{Mr}$. Thomas Bell, in 1800. The leaves of this species are sometimes used as a substitute for those of the tea-tree. *

* Bot. Reg. 
Three beautiful species of this plant have been discovered growing within the same latitudes in America, where the rhododendron has been found to flourish in the old world.

Peter Collinson; Esq. had the honour to be the first who introduced the American rhododendron, maximum, in the year 1736. In the year 1786 Messrs. Fraser, nurserymen in Sloane-square, introduced the Carolina dotted rhododendron, punctatum; and about the year 1810, the same firm raised from seed the dotted-leaved rhododendron, which is a native of the mountains of Carolina. These American species have flowers of a fine pink colour or peach blossom, which form an agreeable variety with the rich violet tints of the former species.

That these plants are nearly allied to the genus azalea, is proved by the experiments of Mr. Herbert, of Spofforth, near Wetherby, who has succeeded in raising a new plant by scattering the pollen from the anthers of rhododendron, maximum, over the stigma of the common white glaucous-leaved azalea, from which seed has been raised, mule plants, which partake of the nature of both parents. It takes after the rhododendron in its coriaceous evergreen foliage, the number of its stamens, the redness and expansion of the 
limb of the corolla; after the azalea in the blueness of the leaves, the tapering of these towards each end, in the cylindrical elongation and whiteness of the tube of the corolla, \&c.

The rhododendrons change their foliage after the blossom is over, and the flower buds are formed of a considerable size in the autumn for the following summer.

We now reckon eleven distinct species of these plants, all of which require to be planted in bog earth, and not in situations too much exposed to the mid day or afternoon sun.

We have already noticed their proper place in the shrubbery in the introduction to this work. We shall add, that when they can be contrasted by the yellow Spanish broom, or other plants of a similar colour, it gives their blossoms an additional lustre.

Clumps of the flame-coloured azalea should shine near those of the purple rhododendron, for as they both flower at the same season the contrast is as rich as a purple robe wrought with gold. It requires the nicest judgment to intermix even those plants which contrast or harmonise the best.

"6 Not chaos like together crush'd and bruis'd, But, as the world, harmoniously confus'd, Where order in variety we see, And where, tho' all things differ, all agree." 
The rhododendron is propagated by layers and suckers, but it is more generally raised from its seed, which resembles small saw-dust. If the seed be covered deep with earth it will not vegetate, and it should be sown as soon as possible after it is ripe, either in a shady border, or in pots filled with fresh loam, and very lightly covered with fine earth. The pots are then to be plunged into the earth in a shady border, and covered with hand-glasses in hard frost; but they should be constantly uncovered in mild weather. When sown early in the autumn they appear in the following spring, and will then require to be shaded from the sun, and frequently refreshed with water during the first summer. When transplanted in the autumn the beds should be covered with moss, to secure them from the frosts of winter and the drought of summer.

The rhododendron is emblematical of the dangers that lurk about the imperial purple. 
208

THE WILLOW-LEAVED SPIRAA. - SPIRAA SALICIFOLIA, SPIRA FRUTEX.

Natural order, Pomacea. Rosacer, Juss. A genus of the Icosandria Pentagynia class.

_ "How far, beyond the transient glare Of fickle fashion, or of formal art, Thy flowery works with charm perennial please."

Mason.

This beautiful species of spiræa, that garnishes its taper stalks with spikes of fleshcoloured flowers so agreeably in the months of June and July, springs in the deserts to cheer the banished Muscovites, whom the tyranny of despotic rulers sends to waste their bloom of manhood in the dreary regions of Siberia.

" Peaceful and lowly in their native soil, They neither know to spin or care to toil;

Yet with confest magnificence deride

The vile attire, and impotence of pride." Prior.

This ornamental shrub begins to flourish about the banks of the river Oby, and from thence becomes more abundant about the 
Jenisea, and in the country beyond the lake Baikal.

It seems to love the soil of this country, as it has by some accident crept out of the garden into our hedgerows, where it has been found in Westmoreland, in many places on the borders of Winandermere, and also between Pooldridge and Colthouse, near Hawkshead, Cumberland, and in a wood at Hafod, Cardiganshire. From these circumstances some authors have supposed the spiræa salicifolia was a native of this country, but this opinion is refuted by the plant itself, which seldom or ever perfects its seed in this island, even under the most favourable circumstances of cultivation. It is increased rapidly in moist situations by suckers, and its whole height is one year's growth from the root, like the stalks of the raspberry plant. In rich ground the shoots are often five or six feet high, but in moderate soil not above three or four feet. The leaves are set alternately on the rods, and are of a bright green, and therefore should be planted with evergreens of a dark shade, which heighten the effect of the spikes or clusters of little flowers that form a conical top to each branch; and as the numerous stamens stand out much beyond the petals, and are of the same pink 
or flesh colour, it forms altogether a singular and pretty flower, but rather of a stiff than a graceful nature. They have a slight scent, just before the petals expand, and the colour is then of a fine rose tint, but when fully opened they are of a pale flesh colour; and as each of these small corollas has about twenty stamens, headed with a yellow anther, it may be called Titania's pin-cushion, as the racemes appear to be crowded with fairy pins.

It appears, from Rea's Flora, that the common spiræa frutex was cultivated in our gardens previous to 1665 .

This shrub is encreased by suckers, or by parting the roots in the autumn.

The Hortus Kewensis notices seventeen species of spiræa, besides several varieties. 


\section{SPRUCE KIR. - PINUS ABIES.}

\section{Natural order, Conifere. A genus of the Monocia Monadelphia class.}

" High o'er the pines, that with their darkening shade Surround yon craggy bank, the castle rears Its crumbling turrets."

Mickle.

"Here waving groves a chequer'd scene display, And part admit, and part exclude the day." Popk.

The Norway spruce, abies, is the loftiest of all the European trees, often attaining the height of 150 feet, whilst in shape it forms one of the most elegant pyramids of this genus of plants; and for the thickness of its foliage, and the beauty of its vivid green, it is so superior to the common Scotch fir, that it is now much more frequently planted in ornamental grounds than any other species of pine, excepting the larch.

The leaves of the spruce are set on the branches, solitary, and without order, but on all sides; they are slightly keeled on both sides, and shining on the upper surface. Both the catkins and the cones when young 
are of a purple colour; each cone contains about 365 seeds, being generally eight rows of scales, of twenty-three each, and every scale contains two seeds.

This towering tree is a native of the North of Europe, and abounds in the vast woods of Norway, from whence immense quantities of this timber are annually imported into this country for the purposes of building, it being the white deal so much used in modern houses.

It seems to have been cultivated in this country at an early period. It was noticed as long back as 1548; and Gerard tells us, in 1597, that he had seen it growing in Cheshire, Staffordshire, and Lancashire; and as this author had visited Norway, where he had seen " the goodliest trees in the worlde of this kinde," we cannot suppose that he could have been mistaken. Nor can we be surprised that Evelyn should only have noticed a few solitary trees of this kind, when Plot tells us, that during the civil contest in the reign of Charles the First, "wood has become so scarce, that it is a common thing to sell it by weight, not only at Oxford, but in other places in the northern parts of the shire; if brought to moreat (market), it is ordinarily sold for about one shilling the hun- 
dred weight, but remote from great towns it may be had for seven-pence," which, according to the value of money in that age, would be equal to nearly a half-penny per pound weight; and if we take into consideration that mineral coal was then but little used as fuel, it is not extraordinary that every tree fit to cut should then have bowed to the hatchet.

No sooner, however, was the nation in a state of quiet and settled govermment, than the poverty of the woods and forests was immediately discovered, and Evelyn sent forth his Silva, with the most persuasive arguments in favour of planting, to which we owe, even at this day, the existence of many noble trees.

The planting of trees seems to be almost a religious duty with those who have suitable lands, for as our ancestors planted for us, so are we in honour bound to plant for posterity. Those who plant oaks look forward to future ages only, and therefore deserve the highest commendation; but all our praise and admiration of such acts cannot be so valuable to them as their own satisfaction, which must arise amidst groves of their own planting, for there is a serene and settled majesty in woodland scenery, that enters into the soul, and dilates it, and fills it with noble ideas. It is 
observed that few men live to see the full beauty of the trees they plant. The cause of this is principally that they do not begin to plant until they are old, for youth is too frequently employed with the hewers to attend to the planter. But it is never too late in life to plant, and the beauty of young trees may be compared to the beauty which the parent discovers in his infant children; the pleasure of seeing them expand is perhaps quite equal to what is enjoyed when fully matured by time.

The Norway spruce fir offers particular advantages to the planter, as it is equally durable at all ages, like the larch, and therefore will bring a price whenever cut, even of the smallest dimensions; and as it grows perfectly straight, it soon becomes fit for scaffolding poles, and other similar purposes, and as it increases in size, for masts of vessels, \&c. Loudon observes, that this tree is peculiarly valuable as a nurse, from being evergreen, and closely covered with branches, by which radiating heat is retained; from its conical shape and rigid stem, by which it does not suffocate or whip the adjoining trees. It must be observed, however, that this tree will not thrive in all situations where the common pine and larch flourish, as the spruce 
loves a cold soil, and rather sheltered situations.

The finest specimens of these trees which this country now boasts of are at Blenheim, Harefield Park, and at Temple Newsham.

'The air that is impregnated with the exhalations of these trees is reckoned very wholesome, particularly for phthisical persons; and the fresh cones boiled in whey, and beer brewed with the tender tops of the branches of the spruce, are accounted good in inveterate scurvies.

From the resin which this tree yields by incision, Burgundy pitch and turpentine are procured.

The American spruce, alba and nigra.

The cones, both of the white and the black spruce, were sent from Virginia to England by Mr. Bannister, about the year 1700, and several trees were raised from them, in the gardens of Compton, Bishop of London, at Fulham, and at some other places. About the same time cones were also brought from Newfoundland, from which many fine trees were raised in Devonshire. 'The white spruce is known by a pale bluish-green leaf, and it is from this variety principally that the essence of spruce is obtained, which is so celebrated 
in forming spruce beer; but a decoction may be procured from the young shoots of either of the species of spruce, that answers every purpose for making this antiscorbutic beer, the most simple receipt for brewing of which, is to take sixteen gallons of water, and boil the half of it; put the water thus boiled, while in full heat, to the reserved part, which should be previously put into a barrel or other vessel; thereto add sixteen pounds of treacle, with a few table spoonfuls of the essence of spruce, stirring the whole well together; add half a pint of yeast, and keep it in a temperate situation, with the bung-hole open, for two days, till the fermentation is abated; then bottle it off, and it will be fit to drink in a few days afterwards. 


\section{SUMACH. - RHUS.}

Natural order, Dumosce. Terebintacee, Juss, $A$ genus of the Pentandria Trigynia class.

"Let fancy lead, And be it ours to follow, and admire, As well we may, the graces infinite Of nature."

Hurdis.

"Not a flower

But slows some touch, in freckle, streak, or stain, Of his unrivalled pencil. He inspires

Their balmy odours, and imparts their hues, And bathes their eyes with nectar, and includes, In grains as countless as the sea-side sands, The forms with which he sprinkles all the earth."

'THe name of Sumach for this shrub is the same by which it is distinguished by the Arabs. 'The Greeks called it Pous, rhus, and rhous, from the verb rheo, I run, or flow, on account of the nature of the root, which spreads itself to a great distance, sending up numerous suckers. 'The Latins followed the Greek name of this plant; but as its seed was anciently used for seasoning meat instead of salt, 
it was called Rhus Obsoniorum*, and Rhus Coriaria, from its use in dressing of leather, and for which purpose its branches are still in great demand among the Turks for tanning their Morocco leather. The elm-leaved sumach, rhus coriaria, grows naturally in India, Syria, about Aleppo and Rama, in Italy, Spain, and the south of France, and also near Algiers in Africa.

Dr. Turner says, in his Herbal of 1568, " The sumach groweth in no place of England, or Germanye, that ever I sawe, but I have sene it in Italy, a little from Bononye, in the mounte Appennine." It appears, however, to have been cultivated in this country previous to 1597 , as Gerard mentions it in his Herbal of that year; and from the Catalogue of the botanic garden at Oxford, it appears to have been planted there before the year 1648 .

The flowers of this species of sumach grow in loose panicules at the end of the branches, each panicule being composed of several thick spikes of flowers sitting close to the footstalks; they are of a whitish herbaceous colour, and

* The Tripoli merchants still find sale for the seeds of this shrub at Aleppo, where they are in common use there at meals to provoke an appetite, being ground into powder as we grind mustard seed. 
appear in July, but seldom if' ever ripen their seeds in England.

The Virginian sumach, rhus typhinum, is a native of North America, as its name imports. Parkinson is the oldest author who notices it in this country: he tells us, in 1629, that it was then "only kept as a rarity and ornament to a garden and orchard." This species of sumach was formerly called the Stag's-horn tree, from the branches being shaped like those of the stag's-horn, and like them covered with a soft velvet-like down, which, both in colour and texture, resemble that of a young stag's-hom.

This tree is both singular and beautiful, the flowers being produced in close tufts at the end of each branch, of a reddish purple colour, in the shape of a spearhead. They make their appearance in July, and are then succeeded by the seed, which is inclosed in a woolly succulent cover of a purple colour, which has a good effect during the whole of the autumnal months.

The leaves are long, and elegantly pinnated with six or seven pairs of leaflets, terminated by an odd one, which hang in a most graceful manner. The shrub grows from ten to fifteen feet in height, and therefore should fill a middle station in the shrubbery, between 
tall evergreens and lower shrubs. The variety this plant affords in the autumn, by the gay tints of its foliage, is not surpassed in beauty by any shrub we possess, as it is sometimes quite purple, and at others of a fine red, before it changes to its last feuillemort colour. It is one of the trees that is particularly handsome to look down upon.

This shrub, as well as the elm-leaved sumach, is used for tanning leather; and the roots are used in medicine in Virginia and Carolina.

The sumach sends up numerous suckers, by which means it is so easily increased, that there is little occasion to sow the seed when once a single plant is obtained. The Hortus Kewensis notices eleven species of this plant that will endure our winters, and nine species that require the greenhouse, and one the stove. 
SYCAMORE, or GREAT MAPLE. - ACER PSEUDO-PLATANUS.

Natural order, Trihilata. Acera, Juss. A genus of the Polygamia Moncecia class.

\footnotetext{
"Nor unnoticed pass

The sycamore, capricious in attire,

Now green, now tawny, and, ere autumn yet

Have changed the woods."

COWPER.
}

THE great maple-tree was called, in Greek,

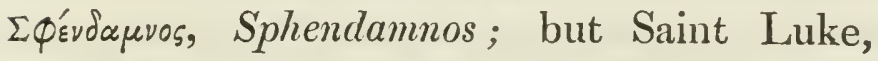
who wrote his gospel in Rome, probably changed the Latin name of this tree into

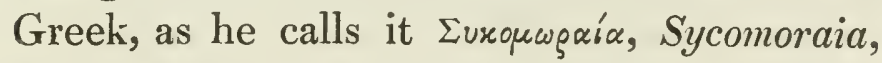
(chap. xix. ver. 4.), from whence we have evidently derived the name of Sycamore.

The sycamore became celebrated as being the tree on which Zaccheus climbed to see Christ pass on his way to Jerusalem, when the people strewed leaves and branches of palm and other trees in his way, exclaiming, "Hosanna to the son of David;" and to commemorate which, the Catholic Church still retains the practice of blessing branches 
of the palm-tree on the Sunday before Easter, which is hence called Palm Sunday. In Germany, they consecrate branches of willow, as that was supposed to have been one of the trees from which the disciples gathered boughs for the purpose mentioned, and this is also the tree which is still used for the same reason in many parts of this country. In Switzerland the pine is used. In France the box, excepting the southern provinces, where, as well as in Spain and Italy, the palm is still employed. *

Notwithstanding the Hortus Kewensis, and the British Botanist mention the sycamore to be a native tree of this country, we certainly cannot consider it in any other light than an exotic. Dr. Turner does not mention even having seen this tree in his time, 1568, and Gerard says, in 1597, "The great maple is a stranger in England, only it groweth in the walkes and places of pleasure of noblemen, where it especially is planted for the shadowe sake, and vnder the name of sycomore tree." Parkinson makes the same observation, in 1640, and says, "It is no where found wilde or naturall in our land that I can learne, but

* See the history of the palm-tree in the Pomarium Britannicum. 
onely planted in orchards or walkes for the shadowe's sake."

Evelyn says, positively, that it is not indigenous to our soil.

Chaucer, it is true, mentions the sycamore as long back as the fourteenth century; but as it is described by him in a kind of poetical dream, we conclude it was from the knowledge he obtained of this tree when abroad; but even if it were known in England in his time, it was evidently rare, as his verse insinuates; and as it may not be uninteresting to many of our readers to have Chaucer's description of an arbour, we give the following extract:

" Till it me brought

To a rich pleasaunt herber wel ywrought,

Which that benched was, and, with turfes new,

So small, so thick, so short, so fresh of hew,

That most like to grene woll, wot I, it was.

The hegge also - that yeden in compas,

And closed in allè the grene herber,

With sycamor was set, and eglatere,

Wrether in fere so well and cunningly,

That every braunch and lefe grew by mesure

Plain as a bord, of an height, by and by;

I se neuer a thing (I you ensure)

So well ydone; for he that toke the cure

It for to make, (I trowe), did all his peine

To make it pass, alltho that men have seine."

St. Jerome, who died in the beginning of the fourth century after.Christ, tells us, that he saw the sycamore tree which Zaccheus 
climbed up to see our Saviour ride in triumph to Jerusalem, which proved that it would stand long without decaying; and perhaps this motive induced religious persons in this country to plant it near their dwellings. Evelyn condemns the practice of planting sycamorès in gardens. He says, in his Silva, "It is much more in reputation for its shade than it deserves; for the honeydew leaves, which fall early, like those of the ash, turn to mucilage and noxious insects, and putrefy with the first moisture of the season, so as they contaminate and marr our walks; and are, therefore, by my consent, to be banished from all curious gardens and avenues." Vauxhall and Marylebone gardens were originally planted with sycamore-trees.

The sycamore timber was much more in request in the time of trenchers and wooden bowls than at present; for since the use of earthenware has become so common with all classes, the demand for this, and other soft white woods, has greatly decreased.

Like the birch tree, the sycamore gives out great abundance of saccharine juice, when tapped, either in the spring or autumn, from which wine was formerly made in this country; and Dr. Tongue tells us, in the Philosophical Transactions, vol. iv., that the sap of 
this tree is sweet and wholesome, and in a short time the trunk yields sufficient quantity to brew with; so that with one bushel of malt is made as good ale as four bushels with ordinary water. The sycamore has always been esteemed a good fire-wood, which in former ages was no small recommendation, and the timber is valuable for the interior parts of buildings.

The sycamore is highly ornamental in rural scenery, particularly in the neighbourhood of plantations of fir and pine, where a few scattered trees of this description should always be intermixed to relieve the monotonous appearance of the dark tints of those spiral trees; for in the spring the fine green of the sycamore leaf contrasts as agreeably as its varying foliage is embellishing in the autumn.

An enormous tree of this kind formerly stood before the Duke of Dorset's seat at Knowle, in Kent, which measured from twelve to fourteen feet in circumference.

It is not more singular than true, that we find those trees which are best enabled to resist the spray of the sea less frequently planted in those situations than elsewhere.

The sycamore thrives on the coast when planted there, even better than the elm; for, like the ash, it does not send out its leaves

VOL. II. 
until after the March winds are exhausted; and it sheds its foliage in the autumn, before the equinoctial gales commence. The tree is of quick growth; and if we may judge from those in the master's piece, at Sidney-Sussex college, in Cambridge, it is durable, as those trees were planted in 1607. That sycamore-trees may be planted to considerable advantage in many situations, may be judged from a statement that is made in a work entitled " Practical Economy," which tells us, that a piece of ground in Scotland, not worth thirty shillings per acre, for agricultural purposes, was planted with sycamores, and at the end of sixty years the trees fetched such a sum as paid fourteen pounds per acre per annum during that long period.

The flowers of the sycamore-tree are suspended in long bunches, and usually blow about the end of April, when, if their pollen be obtained and viewed through a microscope, each particle will be found of a globular shape; but if it be touched with any thing moist, the globules burst open with four valves, and they appear in form of a cross.

"What vast perfection cannot nature crowd Into a puny point!" Hurdis.

These trees are propagated by gathering 
the seeds in the autumn, when ripe, and sowing them as has been directed for the ash. In the spring they will appear, and, if the ground be tolerably good, will make a shoot of eighteen inches by the autumn. In the following spring they should be planted in the nursery in rows, two feet and a half from each other. Here they may remain till they are large enough to plant out for good, without farther trouble than taking off unsightly side branches, and digging between the rows every winter. 
SYRINGA, OR MOCK ORANGE. - Philaalphus.

Natural order, Hesperidec. Myrti, Juss. A genus of the Icosandria Monogynia class.

"The sweet syringa yielding but in scent To the rich orange ;"

Mason.

" Oh! who that loves with curious eye to trace Nature's least beauty, or most transient grace, Can walk a garden's cultivated ground, At morn, when flowers their fragrance breathe around, Nor feel, as he inhales the balmy air, And views the world of loveliness that's there, His genius and his taste grow more refin'd, And Fancy's vista open on his mind."

J. Player.

THE Syringa, which covers its branches so beautifully with ivory-coloured flowers, and embalms our groves with its fragrance so agreeably, in the months of May and June, has been made the emblem of memory, because when once we inhale this penetrating odour, it continues to follow us every where for a considerable time. 
"Oh! memory, thou fond deceiver,

Still importunate and rain, 'To former joys recurring ever,

And turning all the past to pain.

'Tho' like the world, the opprest oppressing,

Thy smiles increase the wretch's woe:

And he who wants each other blessing,

In thee must ever find a foe."

Goldsmith.

The Greeks named this plant $\Phi_{i} \lambda \alpha \delta \varepsilon \lambda \phi \circ$, from Ptolemy Philadelphus, king of Egypt; but on what account we are left to surmise. The name of syringa comes from the Greek word syrinx, flute, because it was one of the woods from which musical instruments were manufactured.

It is frequently called the mock-ormine, from the resemblance the flowers and their perfume have to those of the citrus tribe. The petals of these flowers are frequently used with black or Souchong tea, to which they give the flavour of gunpowder tea; and the young leaves are often sent to table with spring sallad, on account of their having the taste of fresh cucumbers.

The syringa mixes very agreeably with evergreens of a dark tint, as its own foliage is of a yellowish or apple green, and the white flowers are seen to greater advantage when interspersed with deeper coloured plants.

Q 3 . 
Although this shrub is never injured by the severity of our winters, yet it often suffers in the spring; and the beauty of the leaves and flowers are hurt when planted in exposed situations. One of the great recommendations of this plant is, that it will thrive in confined places, and under the shade and drip of trees, as may be particularly observed in the walks - of Kensington gardens, where there are many very old and lofty shrubs of this kind growing under the elms, where they scarce get a gleam of the sun's reviving beams. It is with particular pleasure that we see these fine grounds so well protected by keepers, and so improved in neatness; but it would still be a great improvement to these walks, were the borders enlivened with hardy native flowers, such as the primrose, blue bottle, wood anemonies, and other similar plants that love the shade; which would give the close-pent man an opportunity to peep at nature. But probably it is imagined that

\section{— such a gloom}

Suits well the thoughtful, or unthinking mind; The mind contemplative, with some new theme Pregnant, or indisposed alike to all."

Cowper.

'The native place of this odorifercus flower- 
ing shrub seems undecided on. Linnæus says, but with doubt, about Verona. Ray observed it near Mount Saleve in Savoy, far from any house; but he did not venture to pronounce it wild there. Haller and Krocker speak of it only as a denizen; and Allioni as of exotic origin. Villars says it is not indigenous to Dauphiné, though it is found in hedges far from habitations. From its being more familiar to the Greeks than to the Romans, who had no Latin name for this plant, we may safely surmise that it is a native of more eastern countries.

The syringa was common in this country in 1597 ; as Gerard tells us, that he liad great plenty of it in his garden.

The Carolina syringa coranarius was introduced in 1738 : this species is inodorous, and therefore preferred by those who find the perfume of the common variety too powerful. We certainly prefer this species for forcing, as we have frequently found the fragrance of the former kind oppressive when placed in warm rooms.

The syringa was found in New Zealand, by Captain Cook, whose sailors used the young shoots as a substitute for tea.

They found the infusion sweetly aromatic and fragrant; in a short time, however, it be- 
came very bitter. It was also found in the same place by Sir Joseph Banks.

The syringa thrives best in a light good earth; and as it throws up numerous suckers, it is easily propagated by them. It may also be increased by cuttings, planted in October, in a moist shady border, or by layers from the young twigs put into the ground in the winter, 
TRAVELLER'S JOY, OR COMMON VIRGIN'S BOWER. - CLEMATIS VITALBA.

Natural order, Multisiliqua. Ranunculacece, Juss. A genus of the Polyandria Polygynia class.

- " and let us o'er the fields, Across the down, or through the shelving wood, Wind our uncertain way.

- and let us read

The living page, whose every character

Delights, and gives us wisdom." Hurdis.

" These, Nature's works, the curious mind employ, Inspire a soothing melancholy joy."

Rev. Mr. White.

This native species of Clematis was first named Traveller's Joy by Gerard, in the year 1597; and we know no person who had a more just claim to give a name to a plant than this author, who was so indefatigable in discovering the history of our indigenous plants, and naturalizing others to our soil. English botanists have therefore preserved the name, through respect to this father of British herbalists. 
" It is," says this Elizabethian author, " called commonly Viorna quasi vias ornans, of decking and adorning waies and hedges, where people trauell, and thereupon I have named it the Traueiler's Joie."

It is called Clematis, from $x \lambda_{\eta}^{\prime} \mu \alpha$, viticula, sarmentum, because it climbs trees, by means of its pliant twigs, like those of the vine, and Virgin's bower, from its use in covering arbours and forming natural bowers. It abounds principally in the counties south of London, and particularly in hilly situations, where the soil is of a chalky nature. The hedges on the Surrey hills, as well as those in Kent, Sussex, and Hampshire, are often covered with this singular vine, the branches of which frequently extend to twenty feet or more, climbing every bush and tree in their neighbourhood by means of twisted petioles, with which they make their hold so secure that it appears almost like instinct to see how firmly they grasp the support they meet with, then falling in graceful festoons from bough to bough, or throwing themselves in all directions over the hedges,

"6 recompensing well

The strength they borrow with the grace they lend." 
The young branches are of a purple colour, and the leaves, which consist of two pairs of leaflets with an odd one, are of a yellow green. The flowers, which appear in July, are in axillary racemens, conjugate, leafy, dividing first into three, then into two smaller branches. The flowers are small, and have four petals, which are a little rolled back, of a greenish white, and they are slightly perfumed. But the principal beauty of this shrub consists in the singular manner by which the seed is covered by a downy substance, and the long plumose tail which is attached to each of these little seeds, which, being in clusters of about twenty, give the appearance of so many bunches of feathers; and the bushes are often seen from October to Christmas completely clad in these vegetable feathery tufts, which seem intended to convey them from hill to hill, where they are hunted by various birds for the sake of the seed, with as much avidity as the hawk hunts the lark. 'The shepherds often cut the old wood of this vine, which they light at one end, and smoke instead of a pipe of tobacco. 


\section{TRUMPET FLOWER. - BIGNONIA.}

Natural order, Personatc. Bignonice, Juss. $A$ genus of the Didynamia Angiospermia class.

"Fleurs charmantes! par vous la nature est plus belle; Dans ses brillans tableaux l'art vous prend pour modéle Simple tribut du cœur, vos dons sont chaque jour Offerts par l'amitié, hasardés par l'amour."

Delille.

This beautiful family of shrubs and climbing plants, which the discovery of a new world exhibited to us without a name, were by Tournefort called Bignonia, in compliment to Abbé Bignon, the librarian to Louis the Fourteenth. The English name of Trumpet flower has been given to this species of plants, because the corolla of the flower is of a tubular shape, somewhat resembling a trumpet.

The ash-leaved trumpet flower, Bignonia radicans, was brought from North America about the year 1640 ; and it is found to be 
be one of the most hardy as well as the most splendid of all the species of these plants, that have yet been introduced into this country. In its native country the Bignonia radicans fixes itself to the foresttrees in a similar manner to the European ivy, putting out little fibrous roots at every joint, from whence the trivial name of radicans.

In this country it is generally planted against a wall, where it strikes into the mortar of the joints so strongly as to support the branches as firmly as the strongest nails can do, although it sometimes reaches to the height of forty or fifty feet. The leaves are produced opposite at every joint, and are composed of four pairs of leaflets, terminated by an odd one, similar to those of the ash tree, but of a much richer green. The flowers have a cylindrical corolla divided into five lips of equal size, of a colour similar to carmine laid over an orange ground. The toothed calyx is persisting and of the same rich colour as the corolla; and as the flower buds are progressive, the branches have a display of blossoms from July to the beginning of November, for as some of the corollas drop off others open in succession. 
The flowers are produced in large bunches at the end of the shoots of the same year, and the effect is magnificent when the shrub is in full blossom. We have found this species of bignonia easily propagated by layers, or cuttings of the same year's growth, with about an inch of the former year's wood. This plant loves a rich soil, and a south aspect. Whilst young it is frequently injured by the ants, that devour the leaves even to a skeleton, and sometimes destroy the blossoms.

We have now about sixty species of this genus of plants, most of them eminent for the beauty of their flowers; but as the majority of them belong to tropical regions, we must not hope to see them mixing with the plants of the shrubbery.

The welted trumpet flower, bignonia venusta, which blossomed in the autumn of 1817, in the hot-house of Lord Liverpool, at Combe Wood, was raised from seed received from the Brazils, by Lady Liverpool; and as it is a native of the same neighbourhood as the common blue passion flower, we are not without the hope that it will be found equally hardy when it becomes enured to our climate. 
This magnificent flower, whose corollas are of the most vivid orange vermilion colour, is correctly represented in the 35th Number of the Botanical Register. 


\section{TULIP TREE. - LIRIODENDRON. - TULIPIFERA.}

Natural order, Coadunatc. Magnolice, Juss. A genus of the Polyandria Polygynia class.

This superb forest tree is named Liriodendron from $\Delta \varepsilon \nu \delta \rho o v$, and $\lambda$ eşrov, lily. As it is a tree bearing liliaceous flowers, it is also called Tulipifera, tulip tree, from the resemblance which the blossoms bear to that flower. The word tulip is of Turkish extraction, and given to the flower on account of its resembling a turban.

The vegetable world cannot present us with a more interesting object than a tree of such exalted stature, covered with a foliage so singular and beautiful, as is the tulip-tree of North America. Its spreading branches give an extensive shade, whilst they are covered with an immensity of large and variegated flowers, that appear placed on the boughs like so many porcelain vases, to catch the dews of heaven. 
It is hardly possible to contemplate this noble tree, without having all sordid and angry passions driven from the breast, and exchanged for those of peace and philanthropy. We wonder, therefore, that the poets, who are naturally lovers of trees, and have awakened our interest so much in favour of most others, should so long have neglected to sing the praise of this sylvan wonder of the new world, as to leave us without a head to our chapter.

Michaux tells us, in his work on the Forest Trees of North America, that the middle and western states abound with the Liriodendron tulipifera, some of which he measured, that were twenty-two feet and a half in circumference, five feet from the ground, and from one hundred and twenty to one hundred and forty feet in height. He tells us, that the timber is one of the most useful species of wood, being smooth and fine grained, easily wrought, and not liable to split, therefore desirable for the turner, as also for carving ornaments, pannels of coaches, chaise bodies, \&c. It is also used for forming canoes : and frequently the trees are of sufficient size to hollow into the shape of those boats, so that they are of one piece of timber. Kalm speaks of having seen a barn of considerable VOL. II. 
size, the sides and roof of which were made of a single tulip-tree, split into boards.

Mr. Catesby, in his Natural History of Carolina, says, there are some of these trees in America which are thirty feet in circumference. There is one inconvenience attending this wood, which is, that it contracts and expands itself more than almost any other timber.

The bark is an aromatic medicinal agent: it is often pounded, and given to horses that have the bots. The roots of the tulip-tree are said to be as efficacious in agues as Jesuits' bark.

In America, these trees are distinguishable at a great distance, even when they have no leaves upon them, as the boughs are unequal and irregular, making several bends or elbows. Kalm observes, that it is very agreeable, at the end of May, to see one of these large trees, with its singular leaves, covered for a fortnight together with flowers, which have the shape, size, and partly the colour of tulips.

The leaves of this tree are generally from four to five inches broad, and about the same in length, of a singular shape, being what is termed abrupt, truncatum, appearing as if their ends were cut off with scissars; the side lobes are rounded, and end in blunt 
points. The upper surface of the leaves is smooth, and of a lucid green; the under side is of a pale green; and as they are supported on foot-stalks of four inches long, they hang and move in a very graceful manner. The flowers are produced at the end of the branches; they are, like the tulip, composed of six petals, three without and three within, which form a sort of bell-shaped flower that encloses the fruit, which is a kind of cone that has a stigma to each globosity. The filaments are numerous, and crowned with linear anthers, growing longitudinally to the sides of the filaments. The petals are of a greenish white, marked near the base with ochre yellow, and spotted with red, that gives them a fine appearance, particularly to look into; but they fall short of that gay appearance which most people expect at first seeing them, from the name being the same as that of the flower so celebrated for its gaudy colours. The flowers appear in July and August, but we know of no instance of their having ripened seed in this country.

The Hortus Kewensis notices the introduction of this tree into England, as long back as 1663; and Ray tells us, that it was cultivated by Bishop Compton, at Fulham, in 1668. When first it was raised in this country, it 
was kept in pots and tubs, and housed in the winter, it being supposed to be of too tender a nature to live in the open air; but in this state it made but little progress, whilst one that was planted amongst other trees, in a wilderness or gardens of the Earl of Peterborough, at Parson's Green, near Fulham, by its growth soon convinced the gardeners of the mistake they had made. This was the first tulip-tree which flowered in this kingdom.

When the hardy nature of this beautiful tree was known, many were planted in different parts of the country, some of which have arrived to a large size, especially those that were set in a rich moist soil.

The finest trees of this kind that we have seen are in the gardens of the Earl of Egremount, at Petworth, in Sussex, one of which has a trunk, that at seven feet from the ground measures ten feet three inches in circumference; it then branches into seven limbs, three of which are five feet eight inches each in girth, and the other four limbs are three feet nine inches each. The height of the tree is about ninety feet, and its boughs extend to a circle of one hundred and eightyninefeet, or sixty-three feet diameter.

There are also some tulip-trees, of great 
bulk and beauty, at Wilton, the seat of the Earl of Pembroke; at Waltham Abbey, and many other places, in various parts of the country. The late Marquis of Londonderry took great delight in a tree of this kind, which grew on his lawn at Craysfoot, in Kent; where long may it remain, sacred, as a memento to mankind, that the most exalted situations are often the most perilous, and that happier hours may be spent under the shade of Liriodendron, than near the blazing splendour of a throne.

\section{— Who, that lives,}

Hath not his portion of calamity?

Who, that feels, can boast a tranquil bosom?

Mrs. Robinson.

Mr. Darby, at Hoxton, and Mr. Fairchild, are said to have been the first who raised tulip-trees in any quantity from seeds, and from them the gardens abroad were chiefly supplied. The original tree at Parson's Green is quite destroyed; not so much by age as by the other trees which were suffered to overhang it, and rob it of its nourishment, from a fear of taking them down, lest by admitting the cold air to the tulip-tree it would be injured.

The French gardeners notice the following varieties of this tree: Ist, Liriodendron acu- 
tiloba, with lobes acute, acuminated: 2dly, L. obtusifolia, with obtuse leaves: $3 \mathrm{dly}, L$. integrifolia, with leaves entire: 4thly, L. flava, yellow-flowered. This last variety deserves the preference, because its flower is larger, of a bright yellow, and sweet perfume.

These trees are propagated by seed, that is now annually imported from America; and it is also increased by layers; but these are commonly two or three years before they take root, and the trees so raised are seldom so fine as those raised from seeds; but, like all other stinted plants, they flower sooner. When raised from layers, we should recommend the branches to be ring-barked, which would facilitate the obtaining roots.

The tulip-tree prospers best in a light, loamy soil, not too dry.

A tree of such extraordinary stateliness and beauty deserves a more frequent place in ornamental plantations than we yet find it occupying. It is a proper ornament for the park, and would, in this situation, become a more durable monument, to commemorate any local or family event, than those generally raised of stone or marble, whilst the difference of expence would be found to be as pence are to pounds. 


\section{TAMARISK. - TAMARIX.}

Natural order, Succulenta. Portulacea, Juss. A genus of the Pentandria Trigynia class.

" On yon rough craig,

Where the wild tamarisk whistles to the sea blast."

H. DAvY.

" Their powers mysterious let thy knowledge shift, Their useful poisons, and their healing gift; Where'er they rise, no part of earth is lost, Since e'en the desert may its beauty boast."

DeLilLe.

Thrs flexible shrub is the Mupirn of the Greeks, and the Myrica and Tamarix of the Latins. The latter name is supposed to have been derived from the Hebrew Tamaris, (abstersio,) on account of its abstergent qualities. It was a celebrated medicinal plant with the ancient Arabians, from whom the Latin authors seem to have borrowed their knowledge of the virtues of this plant; and the high encomiums which these Aisculapian writers bestowed on the tamarisk, induced Grindall, Archbishop of Canterbury, to in- 
troduce it into this country, as a specific in disorders of the spleen. Camden, in his Life of Elizabeth, notices that the tamarisk was first brought into England by Archbishop Grindal; and in the Remembrances for Master S., by Richard Hakluyt, 1582, we are told, likewise, that "when this archbishop returned out of Germany, he brought into this realm the plant of tamariske from thence, and this plant he hath so increased, that there be here thousands of them ; and many people have received great health by this plant." *

Dr. Turner writes fully on this plant, in his Herbal, that was published in 1568; when it appears to have been unknown in this country; for he observes, "It may be named, in English, Tamarisk, because, as we want the bushe, so also we have no name for it in England." This author tells us, that he "saw it in dinerse landes in Italy, in an yland betwene Francolino and Wenish, in Germany, in diuerse places about the Ren, not far from Strasburg; and in Rhetia, in a stony place, som tyme of yeare used to be ouerflowen with the Rhene."

Gerard notices, that it grows in Germany, Spain, Italy, and in Greece; and he tells us, that both species of this plant grew in his garden in 1596. 
Later botanists mention it as a native plant, because Mr. Giddy, and W. G. Mason, Esq. found it growing on St. Michael's Mount, Cornwall, in the year 1794, as also near Hurst Castle, Hants; and Dr. Goodenough saw it near Hastings, in Sussex; but this is by no means satisfactorily proving it to be indigenous to our soil; as in all probability it sprang from cultivation in the two latter places, and from some accidental circumstance on the former spot, for it is of so easy propagation, that the least sprig of it will often take root when thrown on the earth; and its not maturing its seed in this country is a sufficient proof of its foreign origin.

The tamarisk has been frequently celebrated in the verses of the ancient poets: Homer mentions it as the tree against which Achilles laid his spear before he plunged into the Xanthus, to pursue the routed Trojans. It is introduced in the Pastorals of Theocritus, and Virgil has noticed it several times in his Eclogues. Its name may also be found in several passages of the poems of Ovid.

The Romans considered it an accursed plant, and frequently speak of it as the unhappy tamarisk, as it was used for wreaths to put on the heads of criminals. But as a remedy for diseases of the spleen, it was con- 
sidered of such efficacy, that drinking-cups were made out of this wood for those that - laboured under this complaint; and the physicians ordered their patients to eat out of dishes formed from tamarisk-wood.

The magicians used it to impose upon the credulous by their pretended magical powers; and they ascribed qualities to this plant too much against common reason and decency to mention. Pliny mentions its use for besoms amongst the Romans.

It is found abundantly on the mountains of Dauria and Caucasus in the Russian empire; and the Russians and Tartars use a decoction of the twigs in the gout and rheumatism, and contusions of the limbs, as a fomentation; they also drink it in case of internal injury. They make handles for whips, \&c. of the wood.

Dr. Smith remarked this plant in great plenty in Italy, about Sinigaglia, and all along the hedges near the sea, where the sheep preferred it to every other food, never touching any other vegetable while that remained. It grows plentifully also on the coast in Algiers, as well as in Japan. In some places it grows to a tree of middle size; but in England it remains as a shrub, seldom exceeding fourteen or sixteen feet in height. 
The tamarisk thrives in bleak situations by the sea-side, where most other trees and shrubs are cut off by the blast; for the branches of this plant are so pliable, that they bend without resisting the slightest gale, thus reminding us of the fable of the reed and the oak, or the lines of Hurdis.

" And so the storm,

That makes the high elm couch, and rends the oak,

The humble lily spares. A thousand blows,

That shake the lofty monarch on his throne,

We lesser folks feel not. Keen are the pains

Advancement often brings. To be secure,

Be humble; to be happy, be content."

We have few shrubs more graceful than the tamarisk, its slender branches being covered with a chesnut-coloured bark, and garnished with very narrow leaves, lying over each other like the scales of fish, and of a fine brightgreen colour. This plant is in appearance between the cypress and the common heath. Its flowers appear in July, and are produced in taper-spikes at the ends of the branches; they are very small, and set close all round the spike, of a lilac colour, with red anthers. These are succeeded by oblong, acute-pointed, three-cornered capsules, filled with small downy seeds.

When planted in the shrubbery, the tamarisk should mix with plants of broad and fixed 
foliage, as the laurel or holly. It is also calculated to cover the sides of hills, where it is desirable not to take off the view by taller trees; but its principal advantage over most other shrubs is in marine gardens, where it soon acquires sufficient height to protect rosebushes and other low flowering shrubs. The tamarisk is a deciduous tree, although, when in foliage, it has all the character and appearance of an evergreen shrub.

'The tamarisk is easily propagated by planting cuttings of the last summer's growth in a moist soil. The German sort grows naturally in low watery grounds, and is an agreeable ornament to the banks of lakes or rivers.

"Admit it partially, and half exclude, And half reveal its graces." 


\section{VIRGINIAN CREEPER. - HEDERA QUINQUEFOLIA.}

Natural order, Hederacece. Caprifolia, Juss. $A$ genus of the Pentandria Monogynia class.

"T There is a grace in wild variety Surpassing rule and order."

The Virginian creeper, when allowed to climb the trunks of forest trees in ornamental plantations, adds greatly to the beauty of such scenery, by the ever varying colours of its foliage, from green to yellow and brilliant red. In these situations it forms natural and beautiful wreaths and garlands amongst the boughs of its supporter, where, by the gaiety of its tints, it has the effect of the most lively blossoms. The stalks of this climbing plant are provided by nature with the means of fixing themselves to the bark of trees or the crevices of rocks or walls, by means of little fibres, which insinuate themselves, like those of the common ivy ; and it is therefore frequently planted to cover walls and other buildings, particularly as it thrives in confined 
situations, and will flourish in the smoke of large towns.

We remember its covering the entire end of a house in Mortimer Street, in London, where rural scenes and rural sounds are so much out of fashion, that the owner, we are told, cut down this American climber to prevent having his house indicted as a nuisance, for harbouring sparrows, whose twittering commenced too early in the morning for those whose evening parties begin at midnight. These little chirping choristers may not think themselves singled out by this persecution, since Handel himself was indicted for calling forth the strains of the organ at too early an hour for the fashionables in that quarter of the town.

We cannot forbear relating, in this place, the singular devastation that was committed on some rural scenery, in a street leading out of the Strand, where the wife of a respectable tradesman, who never passed her

\section{-__ " brick-wall bounds}

To range the fields and treat her lungs with air,

Yet felt the burning instinct-over head,"

on the leads of her house contrived to form a grove of myrtles, geraniums, and such other plants as Covent Garden affords. Thus she 
managed to peep at nature, without the fear of fences being broken by neighbouring cattle, or trampling sportsmen treading down her fairest hopes, which, however, were soon spoiled by a host of enemies as ravenous as unexpected. The adjoining house was occupied by a furrier, who, finding his muffs and tippets required air, placed them on his leads also, where the heat of the sun soon gave birth to numerous insects, which, escaping from the eggs concealed in the hairs of the fur, flew to the new created Babylonian garden, and there fixed themselves, until every leaf was destroyed; and it was only by the interference of mutual friends and neighbours, that damages were not sought in the Court of King's Bench.

The Virginian creeper grows naturally in all the northem parts of America. It was first brought from Canada into Europe, but at what exact period is uncertain. Parkinson is the oldest writer who notices this plant: he mentions it in 1629, under the title of Virginia Vine; but observes, that it would be more proper to call it Virginia Ivy, which it resembles nearer than the vine; but M. Jussieu is of opinion that it should be removed to the genus Vitis or Vine.

The flowers of this plant are of a greenish 
colour, hanging in little bunches, and are succeeded by berries of a black hue. This fruit is used as a purgative and emetic, and the leaves form a caustic for drawing issues and keeping them open. This plant may be raised from seed, and is easily increased by layers or cuttings, and it will grow in any aspect or soil,

WALNU'T-TREE. —See Pomarium Britannicum. 
VIRGIN'S BOWER. - CLEMATIS.

Natural order, Multisiliqua. Ranunculacex, Juss. A genus of the Polyandria Polygynia class.

" "Tis a bower of Arcadian sweets."

"Where odorous plants in evening fair, Breathe all around ambrosial air."

Green.

'THE sweet-scented virgin's bower, Clematis flammula, whose clusters of small white flowers shed such an agreeable fragrance over our morning and evening walks, during the months of July, August, and September, is a native of the south of France, Italy, the Grisons, \&c., and was cultivated in this country by Gerard, previous to 1596. Yet it is not become so common as might have been expected from its easy propagation, hardy nature, and above all, from its delightful perfume, which greatly resembles that of the hawthorn, excepting that it is not so powerful, and therefore more agreeable to people in general, being less offensive to the head. This climbing or creeping plant

VOI.. II. 
is a proper ornament for rustic porches or arbours, and it may also be planted so as to climb the trunks of laburnums and other trees in the shrubbery; thus giving the grace of a second flowering. We observed the sweetscented clematis planted in the flower parterres of the royal gardens in Paris, where it was tied to a stake and kept cut as a shrub, by which means it was very ornamental, being covered with white blossoms, and at the same time throwing the fragrance of May over the whole gardens. Great quantities of these plants, when in blossom, are also brought to the flower market of that city, in pots, and meet with a ready sale.

The name of Clematis is derived from the Greek $x \lambda \eta^{\prime} \mu \alpha$, because these plants climb trees, by means of their pliant twigs, like the vine. The sweet-scented species is distinguished by the trivial name of Flammula, on account of the burning sensation the leaves give to the tongue.

'The purple virgin's bower, Clematis viticella, is a native of the woods of Spain and Italy, and was also one of the plants which Gerard cultivated in his garden at Holborn, in the times of good Queen Bess. He calls it the Ladies' Bower, "from its aptness to make bovers or arbours in gardens." But this 
species was previously propagated in England by Mr. Hugh Morgan, as early as 1569. The flowers of this kind of clematis are of a bell shape, and generally of a dingy blue or purple colour, although there is a variety of it with red flowers, as also one with double blossoms. The long-flowered virgin's bower, Clematis cylindria, was introduced from North America in the year 1802, by Messrs. Gordon and Thompson, nurserymen, at Mile-End. This species is much more ornamental than the former one, as the flower-petals are of a fine violet colour, edged with white, and white in the inside. 'The yellow-flowered virgin's bower, Clematis ochorlenca, is also a native of North America, where it was observed by Bannister, and cultivated in this country in 1767, by Mr. James Grordon. This species flowers in June and July.

The best mode of propagating these plants, is by laying down the branches in the beginning of July, soon after they have made their first shoots, for it is these young branches of the same year, which take root most freely. When increased by cuttings, they should be planted in March, in pots filled with good earth, and plunged into a moderate hot bed, shaded from the sun, and watered two or three times a week, and in less than two 
months they will have taken root, when they should be gradually inured to the open air.

These plants all require some support, and an open sunny situation, and never appear to so much advantage as when climbing the trunks of trees, or covering alcoves or thatched cottages.

The Hortus Kewensis enumerates sixteen different species of these plants, besides several varieties, all of which are hardy enough to bear the severity of our winters, excepting one from Japan and one from Minorca, that require the greenhouse, and one from Jamaica requiring the stove. 


\section{WILI.OW. - SALIX.}

Natural order, Amentacea. A genus of the Dicecia Diandria class.

Their pendent boughs, stooping as if to drink."

COWPER.

"Thus o'er our streams do eastern willows lean In pensive guise; whose grief-inspiring shade, Love has to melancholy sacred made." Delince.

"To the brook and the willow that heard him complain, Ah willow! willow!

Poor Colin went weeping and told them his pain."

ROWE.

The weeping willow, Salix Babylonica, so much admired when waving its long and slender pendulous branches over our lakes and rivers, is a native of eastern countries, and grew anciently by the waters of Babylon, as its trivial name indicates. It was on this tree that the unhappy Israelites hung their harps, and bemoaned their beloved Jerusalem, during their captivity, and which is so 
pathetically expressed in the following beautiful lines:

" $\mathrm{By}$ the rivers of Babylon, there we sat down, yea, we wept, when we remembered Zion.

We hanged our harps upon the willows in the midst thereof."

Psalm cxxxvii.

The Jews were commanded by the Levitical laws, to keep the festival of the new moon after the harvest, in which they were directed to hold a branch of the willow of the brooks in their hands, singing Hosannah.**

We still retain the appellation of the harvest moon in our almanacks, but our praises and thanksgivings for the bounteous gifts of nature are but feebly and rarely sung in these days of refinement.

'The religion of the ancients consisted greatly in national and public praise and thanksgiving, which must appear on reflection equally desirable with public prayer, since we know not what to ask for our good; but we may always be assured that our joyful expressions of gratitude must be acceptable to the Giver of all good things.

It is related, that Alexander the Great, whilst at Babylon, amused himself in a boat. on the waters of the Euphrates, which ran through that city; and that as the boat passed 
beneath a willow which hung over the river, his crown was taken from his head by the projecting branches, and fell into the water, but was immediately recovered by an expert diver, who happened to be in attendance. This event was considered as the omen of his premature dissolution.

Delille says, in a note in "L'homme des Champs," "Tournefort is the first that made us acquainted with the willow with branches inclined, called the weeping willow. It is even probable that Europe is indebted to this naturalist for it."

It has been stated that we owe the weeping willow to Pope; and this idea was strengthened by a paragraph which appeared in the St. James's Chronicle, August 25 to 27. 1801, that says, "The famous and admired weeping willow, planted by Pope, which has lately been felled to the ground, came from Spain, enclosing a present to the late Lady Suffolk. Mr. Pope was in company when the covering was taken off; he observed, that the pieces of stick appeared as if they had some vegetation, and added, "perhaps they may produce something we have not in England." Under this idlea he planted it in his garden, and it produced the willow-tree that has given birth to so many others." 
Madame de Genlis mentions, in a little work on natural history, that the two finest weeping willows in England, are at Twickenham, in the garden of Pope, standing on a terrace that is watered by the Thames. These two willows, she adds, are equally remarkable for their bulk, and for the surprising extent of their branches, which form two large groves.

The Hortus Kewensis informs us that the Babylonian willow was planted in this country as early as 1692, at which time Pope was only four years of age; therefore those planted by him at T'wickenham, conld not have been the first known in this country.

The celebrated Dr. Samuel Johnson planted a willow of this species in his childhood, near the cathedral in the city of Litchfield, his native place, which has long been shown as a curiosity, both on account of its enormous size, and the popularity of this writer.

The very name of this elegant tree is sufficient to inspire a degree of sadness which is not lessened by the numerous melancholy sonnets that have been written on it, until we scarcely behold a weeping willow without expecting to meet with a sepulchral monument of "Poor Mary Anne," or some other slighted lover, over whom this cmblem of 
grief waves its dishevelled hair in silent sorrow. Lovers formerly made their garlands of this willow, the branches of which are very pliable.

This species of willow grows spontaneously on the coast of Persia, and is planted every where in the Chersonesus Taurica. It is also frequent in China, where we may suppose it is a favourite tree, from the firequent representations the people give of it on their China ware. It is also cultivated in Cochinchina.

The weeping willow is pictured in a view of the village of 'Tomnau, drawn by John Nievhoff, July 3. 1655, in his way to Pekin, with the embassy which the Dutch sent to the Emperor of China in that and the following year; but there is no name given, or particular remark made on this tree: he merely says, "This empire doth also very much abound with trees; not only such as grow in Europe, but several others of a more strange nature, not known in our parts of the world."

Of all the aquatic trees the weeping willow is the most ornamental, when planted in its natural situation. It gives a kind of polish to the scenery, where either natural or artificial lakes are admitted, and, when accompanied by a clump of three or four poplars, its 
effect is greatly heightened by the contrast. This tree is not calculated for what is termed rural or woodland scenery; its softness of tint, and peculiar gracefulness of growth, seem to make it a proper plant for refined or embellished landscapes. It is an excellent tree to plant by the side of fish-ponds, as it is generally found to lean over the water, and by this means afford shade to the fishes, which are frequently lilled by the rays of the sun in hot summers, where there is no shade on the water; and the smaller the pool, the greater is the necessity to give it shade. 'This tree also affords an agreeable canopy to the angler.

"Beneath the quirering sliade,

When cooling vapours breathe along the mead, The patient fisher takes his silent stand, Intent, his angle trembling in his hand:

With looks ummored, lie hopes the scaly breed, And eyes the dancing cork and bending reed.

Our plenteous streams a various race supply, The bright-eyed perch with fins of Tyrian dye, 'The silver eel, in shining volumes roll'd, 'The yellow carp, in scales bedropp'd with gold, Swift tronts, diversified with crimson stains, And pikes, the tyrants of the watery plains." Pope.

'The weeping willow is one of the first trees that gives out its leaves in the spring, and it retains them longer than most other deciduous trees. We hare froguently seen it in the depth 
of winter exhibiting its graceful branches, covered with hoary frost, forming the most magnificent spectacle imaginable, at one moment reminding us of a tree sculptured from the purest alabaster, and the next representing a superb chandelier of glass.

The French distinguish this species of willow by the name of the Grand Signior's or Babylonian Parasol.

'The generic name of the willow, Salix, is derived from salive (to leap), because, as the herbalists observe, "It groweth with that speed that it seemeth to leap ;" and the Greeks called it iт์́, for the same reason-

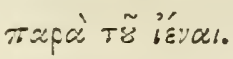

The latest edition of the Hortus Kewensis enumerates sixty-five distinct species of willow; and the British Botanist of 1820 names fifty-six species of this plant, as natives of our soil.

In the terribly superstitious time of the Bruids, itols were formed of the branches of these trees, which were woven into baskets, of sufficient size to hold a great number of persons, who were consumed together, for the purpose of impressing the ignorant with awe, that they might with greater facility continue their horrid impositions.

Herodotus tells us, that the Scythians had 
diviners, who made their conjurations and divinations with wands of willow. We have already so frequently noticed the religious cheats and the abominable rites of the Pagan priests, that we have nothing left but to express our gratitude that we are permitted to live in the blessed days of Christianity.

"Willows in twigs are fruitful."

VIRGIL.

"On willow twigs employ thy weaving care." $I b$.

'The pliant twigs of these trees appear to have been employed for domestic purposes from the earliest ages. The shields of the ancients were woven with wicker-work, and covered with the hides of oxen.

"And bending osiers into baskets weaved." VirGiL.

'The ancient Britons served up their meats in osier baskets and dishes; and so expert were they in this kind of wicker-work, that their baskets were objects of great admiration to the Romans, which we learn from the following epigram of Martial :

Barbara depictis veni bascauda Britannis, Sed me jam mavult dicere Roma suam.

Lib. xiv. Ep. 99.

"A basket I, by painted Britons wrought, And now to Rome's imperial city brought."

Osier baskets were the first manufactured articles that were exported from these king- 
doms. These baskets were of very elegant workmanship, and bore a high price in Italy. Juvenal notices them among the extravagant and expensive furniture of the Roman tables in his time.

Adde et bascaudas, et mille escaria. Sat. xii. v. 46. "Add baskets, and a thousand other dishes."

In early days, the Britons, as well as the inhabitants of other countries, for want of proper tools for sawing large trees into planks, formed their vessels or boats of osiers, and the flexible branches of trees interwoven as close as possible, and covered with skins. *

It was in such slender vessels as these, probably, that some bold adventurers first launched out from the nearest coast of Gaul, and passing the narrow sea that flows between, landed in an auspicious moment on the shores of this inviting island; and being followed by others of both sexes in their successful attempt, began to people the country which they had discovered. This much at ieast is certain, from the concurring testimony of many authors, that the most ancient Britons made use of boats of this construction for several ages.

- Cres. de Bel. Civ. 1. i. c.54. 
Pliny tells us, that Timæus, a very ancient listorian, whose works are now lost, had related that the people of Britain used to sail to an island, at the distance of six days' sailing, in boats made of wattles, and covered with skins. These kinds of boats were still in use here in Crsar's time, who acquaints us that he transported his army over a river in Spain, in boats macle in imitation of those that he had seen in Britain, which he thus describes: " 'Their keels and' ribs were made of slender pieces of wood, and their bodies woven with wattles, and covered with skins."

These ancient British vessels are also described by Lucan and Festus Avienus :

" Primum cana salix, madefacto vimine, parum Texitur in puppim, casoque inducta juvenco Victoris patiens, tumidum circumnatat amnem. Sic Venetus stagnante Parlo, fusoque Britannus Narigat oceano."

Luc. Phars. "Rei ad miraculum

Navigia junctis semper aptant pellibus, Corioque vastum sæpe percurrunt salum."

Fest. Avienus in Oris. Marit.

Solinus gives the same account of the boats in which the ancient inhabitants of Ireland and Caledonia used to pass the sea which divides these two countries: "The sea which dows between Britain and Ireland is so mupiet 
and stormy, that it is only navigable in summer, when the people of these comntries pass and repass it in small boats made of wattles, and covered carefully with hides of oxen."

Gibbon observes, that "if the fact were not established by the most unquestionable evidence, we should appear to abuse the credulity of our readers by the description of the vessels in which the Saxon pirates ventured to sport in the waves of the German Ocean, the British Channel, and the Bay of Biscay. 'The keel of their large flat-bottomed boats was formed of light timber, but the sides and upper works consisted only of wicker, witl a covering of strong hides. These boats drew so little water, that they could easily proceed fourscore or an hundred miles up the great rivers; their weight was so inconsiderable, that they were transported on waggons from one river to another; and the pirates who had entered the mouth of the Seine, or the Bhine, miğht descend with the rapid stream of the Rhone into the Mediterranean."

In Herodotus * we meet with a curious description of the vessels in which the Armenians navigated the Euphrates. 'These vessels were quite flat and round like a shield, composed of willow, covered with hides or skins. 
They were laden generally with palm wine and worked by two men, and on board there was carried one live ass or more according to the size of the raft, which was various. When these vessels arrived at Babylon, which was always their destination, the owners, after having disposed of their cargoes, put up the wicker-work of their boats to sale, and loading the asses they had brought with them with the hides, returned again to their country by land, to perform a similar journey in a similar manner. The impetuosity of the current of the Euphrates made it impossible for them to return by water.

The willow also formed a defence from the unhallowed tread of man over the mouldering corpse of his friends and ancestors.

" Those graves with bending osier bound, That nameless heare the crumbled ground."

Parnell.

'The uses of the willow are perhaps equal to those of any other species of our native trees. Scopoli observes that it supports the banks of rivers, dries marshy soil, supplies bands or withes, feeds a great variety of insects, rejoices the bees, yields abundance of fire-wood, affords nourishment to cattle with its leaves, and yields a succedaneum to Je- 
suit's bark. To which the venerable Evelyn adds, "all kinds of basket work, pill-boxes, cart saddle trees, gunstocks, and half pikes, harrows, shoemaker's lasts, heels, clogs for pattens, forks, rakes, perches, rafters for hovels, ladders, poles for hop vines, hurdles, sieves, lattices for the turner in making tops, platters, small casks and vessels, especially to preserve verjuice in; pales, dorsers, fruit baskets, cans, hives, trenchers, trays," \&c. \&c., to which we may add cricket bats, and numerous other articles where lightness and toughness of wood are desirable.

The wood of the willow although tender, has the property of whetting knives like a whetstone; therefore all knife boards should be formed of this tree in preference to any other.

The bark of the common white willow will tan leather and dye yarn of a cinnamon colour. The Arabs distil their celebrated calaf water from the catkins of any species in which they are fragrant. They use this water as a cooling beverage, or as a febrifuge. In Persia they obtain one of their most esteemed perfumes from the flowers of several kinds of willow.

The downy substance that covers the seeds VOL. II. 
of several species of willow, particularly the bay-leaved, Salix pentandria, forms the soft and warm lining of the nests of the goldfinch and some other birds, from whom we have learnt to collect it as a substitute for cotton in stuffing mattresses and chair cushions, \&c., and when mixed with a third part of cotton, it has been advantageously used for candlewick and many other similar purposes.

The Germans collect it for the purpose of making wadding, so much used in ladies winter dresses, and a useful ordinary paper may be formed of this cottony substance.

The dry husks of these trees remaining after the flowers and seeds are fallen, are wholesome as food, people in times of famine having lived upon them boiled in water.

Some of the kinds of willow, particularly the white willow, will grow to large and lofty trees; they have been seen nine feet in diameter, or twenty-seven feet in circumference, and when perfectly hollow, will give vigorous shoots and flowers by means of the bark. The crack willow, Salix fragilis, grows to be one of the largest trees of this genus.

The osier, Salix viminalis, is much cultivated in osierholts, for making hoops and the larger sorts of baskets, hampers, cradles, bird-cages, \&c. Putcheons and weels for catching eels 
are formed from the twigs of this tree, whilst its trunk prevents the banks of rivers from being washed away by the force of the current.

The basket osier, Salix fissa, is principally propagated in the fens, and is preferred to all other willows or osiers for basket-work.

The great round-leaved sallow, Salix caprea, delights in a dry rather than a moist soil; it is generally used for hurdles, and the trunk is admirable for many purposes with the turner. This tree is known by its round or rather oval leaves, which are rough and waved, indented at the top and woolly underneath. The catkins are very large, and white, and appear early in the spring, on which account they are much resorted to by the bees, on their first coming out of their hives at that early season, when few other flowers are expanded, and the quantities of pollen which the numerous anthers of this plant give, enable them to obtain both food and wax in abundance.

All the sorts of willows are easily propagated by planting cuttings or sets either in the spring or auturnn, but the spring is found to be the most favourable time for this purpose; and as they are quick growing trees, they should oftener invite the attention of those 
who have lands suitable to their cultivation, for as they make almost immediate profit, it must be desirable to attend to their propagation, particularly in those tracts of lands fit only for this purpose, and which at present produce little to the owners; but if planted with osiers and willows of different kinds, would turn to as good account as the best corn land. Martyn says the best time for planting these cuttings in the osier grounds is February, for if they are planted sooner, they are apt to peel, if it proves hard frost, which greatly injures them. These plants are cut every year, and if the soil be suitable they will produce a great crop, so that the yearly produce of one acre has often been sold for fifteen pounds, but ten pounds is a common price, which at the present time is much better than corn land can be made to pay.

In extensive shrubberies several kinds of willows may be admitted, both for ornament and variety, particularly the triandrous, or long-leaved, three-stamened willow, Salix triandra, which gives out such abundance of catkins in the months of April and May; which, by their bright yellow colour greatly enliven the scene, and at the same time render the air agreeable, by the scent which they exhale. 
The male tree should be selected for this purpose, because the female tree quickly sheds its catkins.

The silver-leaved willow, alba serica, should be planted for the contrast it forms with dark evergreen shrubs, and the rosemary-leaved species may also be intermixed with great advantage in many situations.

These species of trees are very interesting to the botanist. In the Linnean system they are ranged in the $22 \mathrm{~d}$ class, called Diocia, from the Greek, meaning two houses, because this class includes the unisexual plants, viz. the male and female flowers being produced on different roots or distinct trees. This class, therefore, in some respects, assimilates the animal and vegetable economy; for in the plants which are perfectly diccious, it is known that the female plants produce no fertile seed, without the proximity of the male plant when in flower. For some curious instances of this fact we refer the reader to our history of the date-bearing palm-tree in the Pomarium Britannicum.

The galls on the leaves of willows are usually of a roundish or oblong figure, and equally protuberant on each side of the leaf, and of a pale green at first; but afterwards of a yellowish, and finally of a red colour. 
When these galls are opened, there is found in them a worm, resembling a caterpillar in figure, with about twenty legs. This creature, when the gall is young, is blue; it afterwards becomes greenish; and finally, when the gall becomes red, it is white. This insect seems to eat in its prison more voraciously than any other gall insect whatever ; for while the gall increases in size, it becomes also thinner in every part, so that the creature, at the proper time, has but little difficulty to get out. When the time of the last change of this insect draws nigh, it leaves the tree, and descends to the earth, where it makes its way into a proper place, and then becomes a nymph,out of which at a proper time issues a four-winged fly, which in its turn lodges its eggs in the leaves of the willow, from whence spring thousands of insects, which become the food of birds, who, in their turn are devoured by man. Thus the willow assists to convert particles of earth and mineral substances, first into vegetable, and then into animal substance, for the subsistence and nourishment of the buman frame, which in its turn is swallowed by the hungry grave,

"Where toil and poverty repose." 


\section{YEW-TREE. - TAXUS.}

\section{Natural order, Conifera. A genus of the Diocia Monadelphia class.}

"s 'The sacred yew, so fear'd in war."

"And the tougher yew

Receives the bending figure of a bow." VIRGIL.

"Th' elastic yew, whose distant wound

With England's rivals heap'd the ground."

ON beholding this sable evergreen, the mind is naturally carried back to the times of bows and arrows, when the yew was as celebrated for causing death and devastation in the field of battle, as the modern engine is at present, which levels rank and file by the dreadful balls that are vomited from its sulphureous mouth.

The Persians, who in the Scripture are called Elamites, were the most expert archers in the world; and Homer thus speaks of the ancient inhabitants of Crete,

"Cydonians, dreadful with the bended yew." 
Virgil notices the elasticity of this wood in the Æneis.

"This foul reproach Ascanius could not hear With patience, nor a vow'd revenge forbear; At the full stretch of both his hands, he drew, And almost join'd, the horns of the tough yew."

Of all the European nations, the English are generally allowed to have been the best archers;

" Skill'd in fight, their crooked bows they bend:"

and to their dexterity in the use of this weapon, is ascribed many signal victories, particularly those of Cressy, Poictiers, and Agincourt, over the French; and that of Hamildon over the Scots. And long before these famous battles were fought, Henry the Second had succeeded in the enterprise of conquering Ireland, chiefly by the use of the long bow, with which the Irish were at that period (1172) entirely unacquainted.

The reputation of the English as skilful archers does not pass unnoticed by Tasso;

"Maggior alquanto è lo squadron Britanno:

Guglielmo il regge, al re minor figliuolo, Sono gl' Inglesi sagittarj." .

Canto I. Stanza 44. 
The yew, however, proved fatal to three of our kings. Harold was killed by an arrow at the battle of Hastings, in Sussex. William the Second was slain by an arrow in the New Forest, Hampshire ;

" Lo, Rufus, tugging at the deadly dart,

Bleeds in the forest like a wounded hart." PopE.

and Richard Cœur de Lion received his death wound from the same weapon, at the siege of the castle of Chalus, near Limoges, in the department of Upper Vienne, in France.

The Cheshire men are supposed to have been the most expert in the exercise of the bow, as it is related that in the year 1397, in the reign of Richard the Second, Westminster-hall being in an extremely ruinous state, that monarch built a temporary room for his parliament, formed with wood and covered with tiles. It was open on all sides, that the constituents might see every thing that was said and done; and to secure freedom of debate, he surrounded the house with four thousand Cheshire archers, with bows bent and arrows knocked ready to shoot. This fully answered the intent, for every sacrifice was made to the royal pleasure. * 
In Switzerland the yew-tree is onty found on the Hatemberg, and the inhabitants of these mountains hold it in great veneration, because formerly they made their cross-bows and wooden lances from it, and then it was forbidden under the most severe penalties, to cut it for other purposes. These simple mountaineers still call it William's tree, in memory of their expert archer William Tell.

Various have been the reasons assigned for planting these trees in our churchyards. The most probable cause seems to us to have originated in the scarcity of this wood, which would naturally be the case as agriculture spread itself over the country, for no farmer could be safe in turning his cattle into fields, where this baleful evergreen offered its poisonous foliage to their bite. And as it appeared necessary to retain this tree for the sake of its assistance in warfare, it is probable that every parish was obliged to plant a certain number of them in their respective churchyards, where they would be secure from the cattle; for had it been merely planted there for the purpose of decorating our churches at Christmas and other festival days, we should have seen the holly planted for the same purpose, which is still more in use for that purpose. 
From what we learn respecting the age of these trees in general, they appear to have been planted about the time of the conquest, 1066; and the same custom seems to have been attended to in Normandy at that period, as Bernardin de Saint Pierre says, "I have seen in Lower Normandy, in a village churchyard, an aged yew planted in the time of William the Conqueror; it is still crowned with verdure, though its trunk cavernous, and through and through to the day, resembles the staves of an old cask."

That our ancestors relied on the yew-tree as a basis of their strength, in the same manner as we now rest on the oak for defence, is too well authenticated to admit a doubt. "Of it," says Mr. Gilpin, "The old English yeoman made his long-bow, which he vaunted, nobody but an Englishman could bend. In shooting he did not, as in other nations, keep his left hand steady, and draw his bow with his right: but keeping his right at rest upon the nerve, he pressed the whole weight of his body into the horns of his bow. Hence arose the English phrase of bending a bow; and the French of drawing one."

In the days of archery, England could not supply its bowyers with a sufficient quantity of yew, and they were obliged by statute to 
import staves of it for making bows, and sometimes at very high prices. All Venetian ships with every butt of Malmsey or Tyre wine, were to import ten bow staves, as the price had risen from two to eight pounds per hundred.

By one of the ancient statutes, a bow of foreign yew may be sold for no more than six shillings.

By the fifth of Edward the Fourth, it was directed that every Englishman in Ireland, and Irishman dwelling in with Englishmen, shall have an English bow of his own height made of yew, wych, hazel, ash, or auburn (supposed to be alder). But " as for brasell (says Roger Ascham) elme, wych, and ashe, experience doth prove them to be but mean for bowes, and so to conclude, ewe of all other things is that, whereof perfite shootinge would have a bowe made."

The thirty-third of Henry Eighth, c. 9., recites the great price of yew bows made of elke (probably elbe) yew; and reduces it to three shillings and fourpence.

From the end, however, of Henry the Eighth's time, archery seems to have been chiefly considered as a pastime. Yet by the eighth of Elizabeth, c. 10., the price of bows is regulated; and thirteenth of Elizabeth, 
c. 14., enacts, that bow staves shall be brought into the realm from the Hanse towns and the eastward.

The comparative value of a yew with other trees, in former times, may be seen from the following table, taken from the ancient laws of Wales.

A consecrated yew, its value is a pound. An oak, its value is six score pence.

A mistletoe branch, its value is three score pence.

Thirty pence is the value of every principal branch in the oak.

Three score pence is the value of every sweet apple-tree.

Thirty pence is the value of a sour apple-tree. Fifteen pence is the value of a wood yew-tree. Seven pence half-penny is the value of a thorn-tree.

Four pence is the value of every tree after that.

The great value set upon a consecrated yew, in the above table, in comparison with a common tree of the same kind, induces me, says Mr. Martyn, among other reasons to think, that the yew was commonly planted in churchyards, rather from motives of superstition, than on account of its utility in mak- 
ing bows, as many have supposed, for a single tree would have afforded a very scanty supply for this purpose. We might have been induced to have formed the same conclusion, had we found but one tree of this kind in each churchyard, but even at the present time it is not unfrequent to see several. In the churchyard at Aberystwith there are eleven yew-trees, the largest of which is twenty-four feet in circumference; and in Mamkilad churchyard there are twelve fine yew-trees; which proves that it was not confined to the planting of a single tree.

It is very natural that the yew should be considered a funeral tree from its having so long occupied a place in our cemeteries, and our fore-fathers seem to have been particularly careful in preserving this tree sacred, the branches of which they carried in solemn procession to the grave, and afterwards deposited under the bodies of their departed friends.

* Let's talk of graves, of worms, and epitaphs; Make dust our paper, and with rainy eyes, Write sorrow on the bosom of the earth, Let's choose executors, and talk of wills."

Shakspeare.

"6 Now from yon black and funeral yew, That bathes the charnel house with dew."

Parnell. 
Our learned Ray says, that our ancestors planted the yew in churchyards, because it was an evergreen tree, as a symbol of that immortality which they hoped and expected for the persons there deposited. For the same reason this and other evergreen trees are even yet carried in funerals, and thrown into the grave with the corpse in some parts of England and Wales. But we are persuaded that this custom was taken from the Romans, and may be traced back even before their existence, or before the doctrine of the immortality of the soul was preached or made known. The custom of carrying fragrant herbs and branches of such shrubs or trees as would prevent infection, is of great antiquity, as well as considerable utility; and of this ancient custom we have frequently spoken in our history of cultivated vegetables; and Statius tells us, that garlands of yew were usually carried at funerals.

"Beneath —, that yew-tree's shade,

Where heaves the turf in many a mouldering heap, Each in his narrow cell for ever laid,

The rude forefathers of the hamlet sleep." Grax. "The grave, dread thing,

Men shiver when thou'rt named,

Well do I know thee by thy trusty yew, 
Cheerless, unsocial plant! that lov'st to dwell Midst skulls and coffins, epitaphs and worms; Where light heel'd ghosts, and visionary shades Beneath the wan cold moon (as fame reports) Embodied thick, perform their mystic rounds. No other merriment, dull tree! is thine." BlaIR.

The dark foliage of the yew-tree seems well calculated to give a solemnity to the village churchyard, and its wide extending branches offer their shade to the rustic Sunday politicians, until the treble bell anounces the time of prayer.

"On Sunday, at the old yew-tree,

Which canopies the churchyard stile,

Forced from his master's company,

The faithful Trin would mope awhile;

For then his master's only care

Was the loud psalm, or fervent prayer;

And, 'till the throng the church-yard path retrod, The shepherd's patient guard lay silent on the sod.

Mrs. M. Robinson.

All nations agree in making this tree the emblem of sorrow, and our poets are not backward in condemning and adding to the revolting character of a tree, whose wood was dedicated to war, and its shade to the dead.

\section{"Where sheds the sickly yew}

O'er many a mouldering bone its nightly dew."

DARWIN. 
The baleful influence of this tree has been greatly exaggerated, and its beauties transformed into objects of disgust and terror. It is unjustly accused of destroying all vegetation by its blast, whilst its beautiful berries have been compared to drops of blood.

The yew is not more remarkable for its toughness and elasticity, than for the fine colour and beautiful grain of its wood.

"Whilst the distinguish'd yew is ever seen,

Unchanged his branch, and permanent his green."

This tree is still to be found in some of our old gardens, and it is common in most of the gardens in Holland, where the art of ancient clipping and cutting is still preserved in all its gloomy stateliness and formal regularity. Vases, pyramids, or globes of yew, are the finish of each angle, whilst in other places, monstrous birds, dragons, and bears, are shaped and modelled out of these trees, as if instead of showing its natural beauties, it was intended to represent the ancient guardian of the garden as recommended by Columella of old, who says,

_ " Chuse the trunk of some huge antient tree;

Rough hew it, use no art; Priapus make.

Him, in the middle of the garden, place,

VOL. II. 
And to him, as its guardian, homage pay, That from your ripening fruits he may deter The plundering boy; and with his threatening scythe, The robber from intended rapine keep." Lib. 10.

That the yew-leaves are a deadly poison is now too well known to require our reciting the opinions of Dioscorides, Galen, Pliny, and other ancient authors; and that its effects are as baneful to man as they are to beasts, we feel it a duty to state, since many fatal accidents have arisen from its juice being administered to children for the purpose of destroying worms. In an age when the affiuent have so munificently established dispensaries throughout the kingdom for distributing medicines to the poor, there can be no excuse for the ignorant dabbling with dangerous herbs, and they should be as particularly cautioned to avoid hungry quacks, as one would the advice of needy lawyers.

Unfortunately the quacks try their arts on the simple, and the attornies on the needy, Johnson says truly,

"Their ambush here relentless ruffians lay, And here the fell attorney prowls for prey."

The profession of medicine has always abounded in men of the greatest liberality and philanthropy. 
" Patient in all their trials, they sustain

The starts of passion, the reproach of pain;

With hearts affected, but with looks screne, Intent they wait through all the solemn scene;

Glad if a hope shonld rise from nature's strife,

To aid their skill and save the lingering life;

But this must virtue's generous effort be,

And springs from nobler motives than a fee." Crabbe.

As few people would in this age be able to plead ignorance of the poisonous nature of yew-leaves, it is a doubt whether their administering this fatal juice to children against worms would not subject them to a trial for murder, in case of accident.

Julius Cæsar, in his Commentaries, says that Cativulces, king of the Eburones, poisoned himself with the juice of the yew. Aubrey relates a case of two women who died from a drink of it ; and Dr. Percival of Manchester mentions another of three children, who were killed by a spoonful of the green leaves, which was given them for worms; they died without agony, or any of the usual symptoms of vegetable poisons. The same quantity of the dried leaves had been given the day before without effect.

A clergyman, who was curate in Sussex, informed me (says Dr. Martyn), that a young lady and her servant, his parishioners, being seized with an ague, were advised to take a 
decoction of rue, which they unhappily mistaking for yew, sent to the churchyard, where a large old tree grew, and gathered a quantity of the leaves, of which they made a decoction, and drank it upon going to bed. The next morning they were both found dead. This was Sunday; on the Thursday following, the clergyman was called upon to bury them; he performed the office on the servant, but the young lady had so fine a bloom on her countenance, that they entertained hopes of her being in a state of suspended animation, and accordingly tried the experiments usual in such cases, but without success ; they determined, however, not to bury her at that time, but kept her until the ensuing Saturday, and even then the corpse remained totally unchanged. What made it more remarkable was, that the accident happened in November, and the weather was of that damp murky kind in which flesh keeps the worst.

We shall point out the pernicious effects of yew on animals in general, that those who possess this tree may take the proper precautions to keep their cattle from it; and we shall also advise such as have yew-hedges in their gardens, to direct their gardeners to burn or bury the clippings, for when thrown carelessly away, serious accidents have frequently 
occurred by their having been eaten by some animal. In August 1822, a valuable riding horse belonging to E. Nicholas, Esq., of Ringmer, in Sussex, was turned into a close where some sprigs of yew-tree (which had been clipped off in the course of the day by the gardener,) were thrown with other rubbish. The horse ate of the yew-tree clippings, and afterwards drank at a pond, which caused the animals almost immediate death.

It frequently happens that due caution is not taken to secure these trees, because we do not recollect their having been the cause of accident, and we observe generally an antipathy in animals to them; yet these very animals may, under various circumstances, be induced to eat of it, when least expected, as happened at Chelmsford, in Kent, in January. 1823 ; when Messrs. Woodward and Co. of that town, turned three of theirvaluable horses into a small close, adjoining which was a yewtree. The snow then lay so thick upon the ground as to hide every other vegetable; the yew-tree therefore, by its tempting verdure, became irresistible. In about three hours from the time that the horses were turned out in perfect health, and full of play, two of them were found dead. Veterinary surgeons were sent for, who soon discovered that these 
animals had eaten of the poisonous tree, and a great quantity of it was found in their stomachs. It appeared that these horses had died without even a struggle.

A filly nine months old, which had been turned in at the same time, although somewhat affected, was saved by the prompt administration of proper antidotes.

Martyn says, in his edition of Miller, "the twigs and leaves of yew, eaten in a very small quantity, are certain death to horses and cows, and that in a few minutes. A horse tied to a yew-hedge, or to a faggot-stack of dead yew, shall be found dead before the owner can be aware that any danger is at hand: the writer has been several times a sorrowful witness to losses of this kind among his friends; and in the isle of Ely had once the mortification to see nine young steers or bullocks of his own all lying dead in an heap, from browzing a little on an hedge of yew, in an old garden, into which they had broken in snowy weather. Even the clippings of a yew-hedge have destroyed a whole dairy of cows, when thrown inadvertently into a yard."

Linnæus says, horses and cows refuse the yew, but sheep and goats eat it with impunity ; but in this instance the learned botanist is in error, at least as far as relates to sheep. 
Some years back Mr. Stubbs, a farmer at Lancing, near Worthing, bought a flock of sheep at a west-country fair, which arriving home late in the evening, were turned into a little grass court at the front of his house; in. which were some yew-hedges, on which the sheep browzed, and in the morning, the greater. part of the flock were dead.

It is true that the yew-trees in the sheepwalks on the Surrey hills, and other places, appear to have had their lower branches browzed on by these animals; but it is also true that a sheep is frequently found dead, and that it is passed over without enquiring into the cause.

Martyn mentions a circumstance where six or eight sheep perished by browzing on this tree.

Of the fruit of this tree Theophrastus says, it is eaten by some persons, being sweet, and considered harmless; but Dioscorides says, the berries bring on a dysentery. However, like most other boys, I have frequently eaten them in my youth, without inconvenience ; and old Gerard tells us, in his usual quaint style, that when he was young, and went to school, he and divers of his school-fellows did eat their fills of the berries of this tree. In Kensing- 
ton gardens, the author of this work observed a middle-aged man gathering these berries, and on enquiring for what purpose they were intended, he was informed that they were esteemed good for a cough, and that he, as well as all his family, had frequently eaten quantities of them for that purpose with success.

Mr. White, in his History of Selborne, says,

In a yard, in the midst of a street, till very lately grew a middle-sized female yew-tree, which commonly bore great crops of berries. By the high winds usually prevailing about the autumnal equinox, these berries, when ripe, were blown down into the road, where the hogs ate them. It was remarkable, that though barrow hogs and young sows found no inconvenience from this food, yet milch sows often died after such a repast; a circumstance that can be accounted for only by supposing that the latter, being much exhausted and hungry, devoured a larger quantity."

It is probable that this injury was caused by the swallowing of a great quantity of the black stones which contain the seed, and not from the mucilaginous pulp which surrounds them, as we observe the wasps are very fond of this fruit, and it will be observed that they 
touch no poisonous berry, and are generally attracted by the most delicious and nourishing fiuits.

The fruit of this tree is of a singular nature, having only that of the Gualtheria similar to it, and we are of opinion that it should rather have been called an open drupe than a berry. In its early state it resembles an acorn in miniature, but in the ripe state the cup becomes of a coral colour, and of a glutinous nature, enclosed in an exceeding fine transparent skin, in which the seed is set, covered by a shell that becomes black as it reaches maturity. We have fiequently observed this fruit on the trees as late as the middle of November, and we noticed them in full flower on the 20th February 1822, in Kensington gardens.

The flowers come out from the side of the branches in clusters; the male flowers having many stamina, are more conspicuous than the female; these are generally upon different trees, as the class Diocia, in which it is placed, denotes; but we meet with some of these trees that have both male and female flowers on the same tree. 'The pollen of these flowers is said to be injurious to bees.

The yew-tree is still found growing in the wild state in many parts of the Surrey hills, 
particularly near Reigate, but more abundantly in the vicinity of Dorking.

Evelyn notices it in the latter place in the time of Charles the Second: he says in his Silva, "He that in winter should behold some of our highest hills in Surrey clad with whole woods of these trees, and box, for divers miles in circuit (as those delicious groves of them, belonging to the honourable, my noble friend, the late Sir Adam Brown, of Bechworth-castle), from Box-hill, might, without the least vio. lence to his imagination, easily fancy himself transported into some new or enchanted country; for, if in any spot in England,

Hic ver assiduum, atque alienis mensibus astas. VIRGIL.

\section{— "Tis here}

Eternal spring and summer all the year."

Mr. Pennant says the yew is to be found wild upon the hills that bound the waters of the Winander, and on the face of many precipices of different places in this kingdom. Mr. Lightfoot says, that it is found here and there in the Highlands of Scotland in a truly wild state; and that at Glenure, near Glencreran, in Upper Lorn, there are the remains of an old wood of yew.

In some parts of Buckinghamshire, it comes up in great abundance from the berries spontaneously. 
In Ireland it was evidently, says Mr. Templeton, very plentiful in former times, being at present common in a fossil state; but it is not now found there, except in cultivation.

Cæsar mentions the yew as very common in Gaul and Germany, and it has been found in North America and Japan.

Its natural situation is in mountainous woods, or more particularly the clefts of high calcareous mountains.

We do not remember a single instance of having met with any young yew-trees being planted in churchyards; and, as many of the old ones are fast approaching to the age of Methusalem, we cannot expect to retain them many ages longer. We shall, therefore, notice some of the most celebrated that are now in existence, and hope soon to be able to record the planting of others; for although we acknowledge there is no actual necessity for these trees occupying a space in the cemetery, yet we have a veneration for the old customs of our ancestors, when they are void of harm, and stripped of superstition; and it must be confessed that no other tree is so well calculated to cast that solemnity over the burialground as the tree we have ever been accustomed to behold in this situation. The yew-tree may be safely transplanted at any 
moderate age, and although it is not of very quick growth, it arrives at a great bulk, and endures perhaps as long as any tree known.

In the church-yard of Aldworth, in Berkshire, is a yew-tree of prodigious bulk, the trunk measuring nine yards in circumference at upwards of four feet from the ground. The shape is very regular, of an urn-like form; the branches spread to a considerable distance, and rise to a great height. All recollection of its age is entirely lost.

There is one of an extraordinary size at Petersham : and another at Lord Newberry's, in the old palace garden at Richmond, planted three days before the birth of Queen Elizabeth.

Mr. Lyson mentions one in the churchyard at Totteridge, the girth of which, at three feet from the ground, is twenty-six feet: and another in Woodford churchyard, which girths at the same height eleven feet nine inches; and at four feet and a half from the ground, fourteen feet three inches. - The spread of its boughs forms a circumference of about one hundred and eighty feet.

Evelyn notices a yew-tree in the churchyard of Crowhurst, in Surry, which was ten yards in compass. "Another in Braburne churchyard, not far from Scotshall, in Kent, 
which being fifty-eight feet eleven inches in circumference, will bear near twenty feet in diameter : not to mention the goodly planks, and other considerable pieces of squared and clear timber, which had been hewed and sawn out of some of the arms only torn from it by impetuous winds. Such another monster is also to be seen in Sutton churchyard, near Winchester."

Several fine old trees are to be seen on some sandy rocks about two miles from Withyam, and five from Tunbridge.

Near the church at Hedson, in Bucks, is a fine growing yew-tree, which measures twenty-seven feet in circumference. There are other large trees on the chalk hills of the same county; and a shady walk of them in the garden of Bradenham-house, near West Wycombe, the branches of which would make excellent bows.

There is a large yew-tree standing in the churchyard at Henfield, in Sussex, whose extending branches cast a thick shade over all the graves in the angle in which it stands. This part of the burial ground is fenced with a holly-hedge, that adds considerably to the gloom of the spot.

The author, when at school in that village, was induced to join five other boys, all about 
fiom ten to twelve years of age, in a frolic that might have created the greatest alarm, and strongly caused a belief that spectres did arise from the grave and walk the earth in embodied shapes. We all slept in the same room; and as the weather was hot, and the moon shining bright, it was proposed that we should descend into the yard for the purpose of getting some water to drink. When there, the beauty of the night tempted one of the party to propose a run. This was instantly agreed to, as well as the leaving our night-clothes in the school-room. The foremost boy bent his course through some fields to the churchyard, where we all followed in a state of nature. It was then proposed that we should show our courage by running round the church separately; and as the moon then shone bright, every object was as visible as in day, excepting under the yew-tree, where we had appointed our resting-place; but whilst dancing over the graves, to reach the place, our attention was suddenly arrested by a figure rising slowly from the earth, which fixed us all to the spot before we reacned the shade which darkened the quarter where the spectre stood, and which our first fright magnified into a monster. It becameerect and motionless, with eyes fixed on us, 
who were also in a state bordering on petrifaction, until the boldest of our party proposed, in a whisper, that we should take hands and go to the spot to see what it was that stood in our way: but the moment we advanced, the object darted from the shade towards the path, where we followed it, and soon recognized the figure of a well-known smuggler, who kept an inn in the village. His fears gave wings to his heels, yet we overtook him, and seizing him by the frock, soon convinced the affrighted Boniface that we had not yet been under ground. He very properly reprimanded us, and told us that he had really imagined that we had come from the graves, but added that such another frolic would be the death of us all. However, if we would go back to the yew-tree, he would give us something to prevent catching cold. Here he produced a small cask of Hollands gin which had been hid in the hedge, and after making a hole with a gimblet, and putting in a quill which he carried with it, we all sucked out of the cask, making him promise never to divulge whom he had seen, and which, for his own sake, he kept sacred. We all returned to our chamber, slept soundly, caught no cold, and never after heard a ghost 
story, but we thought of the Henfield yewtree.

There is a yew-tree in Martley churchyard, Worcestershire, about twelve yards in circumference. In the churchyard at Ashill, in Somersetshire, are two very large yew-trees, one fifteen feet round, with a vast spread of branches, extending $\mathrm{N}$. and S. fifty-six feet. The other divides into three large trunks just above the ground, but many of the branches are decayed. Two trees are now growing on the hill above Fountain's Abbey, near Ripton, which, in 1770 , measured in circumference from thirteen feet to twentysix feet six inches. At Mill Hill, Hendon, in Middlesex, are four beautiful yew-trees, which, in 1797, measured from seven to nine feet each in circumference.

In the churchyard at Aberystwith, are eleven yew-trees, the largest twenty-four feet, and the smallest eleven and a half in circumference.

Mr. Pennant mentions one in Fontingal churchyard, in the Highlands of Scotland, the ruins of which measured fifty-six feet and a half in circumference.

In Ireland, there is a yew-tree at Mucrus Abbey, having one great stem, two feet in diameter, and fourteen feet high, with a vast 
head of branches spreading on every side, and filling the area of the cloisters. Mr. White says, in his history of Selborne, "In the churchyard of this village is a yew-tree, whose aspect bespeaks it to be of a great age: the body is squat, short, and thick, and measures twenty-three feet in the girth, supporting a head of suitable extent to its bulk. This is a male tree, which in the spring sheds clouds of dust, and fills the atmosphere around with its farina. As far as we have been able to observe, the male trees become much larger than the females; and most of the yew-trees in the churchyards of this neighbourhood are males; but this," says Mr. White, "must have been matter of mere accident, since men, when they first planted yews, little dreamed that there were sexes in trees." But we find quite the contrary to this in all the old authors on plants, who speak of male and female trees as familiarly as at the present time, although they had not defined the principles by which vegetables propagated their species. Pliny observes, that when the male trees of the date-bearing palms are cut down, the female trees become widows, and bear no more fruit.

The Latin name of this tree, Tarus, is derived from the Greek Táśs (arrangement), because the leaves are arranged on the branches 
like the teeth of a comb. Some etymologists consider it to have been derived from ró $y_{0}$ (a bow or arrow). Pliny says, that according to some, the toxica, or poison, used for arrows, was called taxica, from this tree; but these poisons were so named from rókov. Others derive it from taxo, in the sense of reprehendo, culpo: this being a poisonous tree.

The yew is easily propagated from seed, which should be sown in the autumn, as soon as ripe, without being cleared from the pulp. The soil should be fresh and undunged, and the situation shady; and the seed should be covered about half an inch thick with earth. The bed must be kept free from weeds, and moistened by watering. In two years the plants should be removed into other beds, and planted in rows about a foot asunder.

The yew may likewise be increased by cuttings of one or two years' growth, planted in a shady border, at the beginning of April, or the end of August. No tree bears transplanting, when old, better than the yew; so that hedges of a considerable height may be formed of it where it is desirable to shut out walks, or hide objects in the shrubbery.

Halifax, in Yorkshire, owes both its name and importance to this tree, if we may credit a story related by Camden, who tells us, that 
it was formerly a despicable village called Hauton; but that the numerous pilgrimages made to that place, and the great and rich oblations which the superstitious left behind them at the sacred yew-tree, caused the rise of this town. The story relates, that an amorous priest falling in love with a pretty maid, who refused his addresses, cut off her head; which being hung upon a yew-tree till it was rotten, the tree became so sacred, not only whilst the virgin's head hung on it, but as long as the tree itself lasted, that the people went in pilgrimage to it, plucking and bearing away branches of it, as a holy relic, whilst there remained any of the trunk, persuading themselves that the small fine veins and filaments resembling hairs, between the bark and the body of the tree, were the hairs of the virgin. 'The name of Halifax imports holy hair.

The timber of this tree is employed by the cabinet-makers and inlayers, and was formerly in great repute for the cogs of mills, axle-trees, and the bodies of lutes, theorboes, and other musical instruments. Mr. Boutcher asserts, upon his own experience, that the wooden parts of a bedstead of yew will not be approached by bugs. 



\section{ADDENDA.}

\section{BUTCHER'S BROOM. - RUSCUS.}

Natural order, Samentacea. Asparagi, Juss. A genus of the Diocia Syngenesia class.

"Where'er we gaze, above, around, below, What various tints, what magic charms, are found!" Byron.

" - easie things, that may be got at will, Most sorts of men doe set but little store."

Spencer.

THis singular and beautiful evergreen shrub, that embellishes our native thickets, deserves a more frequent situation in ornamental shrubberies. It seldom exceeds three feet in height, and therefore is particularly calculated to clothe the foreground of these plantations, and to intermix with the mezereon, the lavender, and other diminutive shrubs, where the rich blue green of its stiff and sharppointed leaves at all times forms a happy contrast; and. which are no less gay than curious

$$
\text { x } 3
$$


during the winter months, when its bright scarlet fruit appears placed on the centre of the upper surface of the leaf, in a manner different from any other native plant we possess.

The flowers appear in March and April; they are of a diminutive size, and of a greenish white colour, forming a small star on the leaf when expanded. But, on close examination, the flowers will be found not to grow out of the leaf, but on a pedicle from the bosom of it, which is immersed beneath the outer coat, whence it may with ease be dissected.

The ancients considered this plant a species of myrtle, as its Greek name indicates,

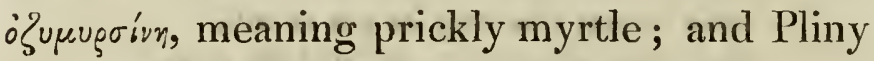
tells us, that the Latin name in his time was Chamcemyrsine and Oxymyrsine. In French it is named Houx Frelon, and Petit Houx, little holly; and in English it is frequently called Kneeholm, Kneeholly, and Kneehulver. The name of Butcher's Broom was given to it from the custom of binding it into besoms for sweeping butchers' blocks, and defending their meat from flies.

M. Jussieu ranges it in the family Asparagi; and the young shoots, which spear out of the ground in a similar manner, were formerly gathered and eaten like asparagus. 
Gerard tells us, that it formerly grew upon Hampstead-henth, and it may still be found in many places in the southern and midland counties of this country; but it will not thrive in northern countries, nor will it bear the winter of Sweden.

It is also a native of Asia and Africa, and was in ancient times greatly esteemed for its medicinal qualities, the root being recommended as an aperient and diuretic in dropsies, urinary obstructions, and nephritic cases.

Dioscorides highly extols its deobstruent and diuretic powers. Riverius relates a case of dropsy successfully treated by a decoction of the roots. Bauchin and several other writers give strong cases of its effects in dropsy; but it is in the early stage of dropsy that this medicine is of the most value.

Etmuller strongly commends this plant as a valuable remedy in scrophulous tumors and ulcers; he recommends a drachm of the powdered root to be taken every morning. It is but little used in modern practice; but may perhaps be again restored to its former celebrity, when some other simples are discarded from the Materia Medica. 


\section{GUM CISTUS. - CISTUS LADANIFERUS.}

Natural order, Rosacea. Cisti, Juss. A genus of the Polyandria Monogynia class.

Coeval race with man! for man you smile;

Why not smile at him too: you share indeed

His sudden pass; but not his constant pain."

YOUNG.

THE beautiful family of plants comprised under the tribe of Cistus are sufficient to form a separate and interesting work.

The transient nature of their blossoms extend through their numerous race, from the most minute that creeps the rock, to the tallest shrub that heads their family. None can be found to possess a flower which lives to see a second sum. But as they have a great profusion of flower-buds, this imperfection is the less regretted; and we find them emblematical of popular favour, smiling on this spray to-day, on that to-morrow, ever changing, ever gay; but no sooner received than withered., But,

__ " ye painted populace!

Who dwell in fields, and lead ambrosial lives:

In morn and evening dew your beauties bathe,

And drinl the sun, which gives your cheeks to glow ;" 
you feel none of the pangs that pain the disappointed man, who survives you to endure the noxious vapour and the blast of winter.

The gum cistus is scarcely surpassed by any of the vegetable ornaments of the shrubbery, as its flowers are both conspicuous and beautiful, from the month of June to the end of August, being of the size of a middling single rose. 'The petals are of a clear white, with a fine purple spot at their base, and crumpled like the petals of the poppy. "The shrub grows to the height of from four to six feet, and spreads to a considerable extent; the foliage is of a dingy green on the upper surface, and whitish on the under side, and remains on the branches all the winter. The whole plant exudes a sweet glutinous substance in warm weather, which has a very strong balsamic scent, and perfumes the air to a great distance. Mr. Swinburn remarks, that the cistus, which grows in great abundance in the waste lands of Sicily, exhaled so powerful an effluvium, when the sun had been risen some time, that it quite overcame him. Fable informs us, that the Greeks named this plant K $\sigma^{\circ} 5$, from a youth named Cistus; but naturalists suppose it to have been so called, because the seed is inclosed in a cisla, or capsule. 
The Latins adopted the same name, which has been followed by all the European languages.

In English, it is frequently called the Rock Rose, because it grows naturally in rocky soil and situations. The trivial name of Ladaniferus is added to this species of cistus, because in warm climates it produces a gum or drug called Ladanum; which is a medicine of great antiquity, and considerable utility in pharmacy.

Dioscorides relates, that ladanum was formerly collected by means of goats, which, browsing on these shrubs, returned to their sheds with their beards loaded with a glutinous substance collected from the leaves of the cistus, which the peasants combed off, and formed into little lumps.

Tournefort tells us, that the common way of gathering the ladanum, when he was in the Levant, was by brushing it off the leaves with a sort of whip, composed of many lashes, or straps, to which it adhered; and from these it was taken off with knives, and formed into Iittle cakes. Bellonius also notices, that it is collected by slightly brushing the shrub, in the heat of summer, with a kind of rake, having several straps or thongs of leather fixed to it, instead of teeth. 
There are two sorts of ladanum in the shops. The best, which is very rare, is in dark-coloured masses, of the consistency of a soft plaster, which becomes still softer on being handled. The other is in long rolls, coiled up, and much harder than the preceding, and not so dark. 'The first has commonly a small, and the last a very large admixture of fine sand, blown upon the juice from the sandy soil where it is found. The best ladanum is brought from Candia and other places in the Archipelago; where the perfume of this drug is so greatly esteemed, that both the Greek and Turkish ladies carry little balls of it to smell to : the fume of it is - said to comfort the brain. Outwardly applied, it strengthens the stomach, and stays vomiting ; and it is said to be an excellent balsamic in dysenteries and hoarseness.

Dale says, it mollifies, digests, maturates, and attenuates; and that, externally applied, it softens, and is anodyne, and good for the toothache, heartburn, pains of the stomach, and hysteric fits. The chief use of ladanum in modern practice is in fuming, its fragrant smell having made it a coustant ingredient in such preparations. Sometimes it is used in troches; and in the Paris Pharmacopocia, there is a pectoral troche in which there is a 
good quantity of ladanum, with musk and amber. The ancients steeped the flowers of the cistus in their wines that had become tart, to correct the effects of their acidity; and this resinous union, nauseous as it may appear to us, is still liked by the natives throughout the Peloponnesus, who continue to mix resin to correct the newness of their wine, and render it fit for immediate consumption.

The dedication of the cone of the pine-tree to Bacchus is traced by Chateaubriand, with some plausibility, to this custom.

At what period the gum cistus was first cultivated in England is uncertain. In 1568, Turner says, "I haue sene it in Italy in certaine gardines, and ones in Englande, in my lordes gardine at Sion."

It grows spontaneously on the hills in Spain and Portugal; but they do not collect the ladanum in these countries.

The gum cistus flourishes best in a sheltered and warm situation, and thrives well on the sea coast, when not too much exposed to the cutting winds. It is propagated by seeds, and also from cuttings. 


\section{ADDENDA ro THE LARCH;}

FROM THE OBSERVATIONS AND EXPERIMENTS OF HIS GRACE THE DUKE OF ATHOLL.

THE introduction of this most valuable tree into Scotland, at least into the county of Perth, took place in the year 1738 ; when a highland gentleman (Mr. Menzies, of Glenlyon, Perthshire), brought a few small plants from London, his servant carrying them on horseback on the top of his portmanteau.

Some of these plants, says his Grace, he left at Monzie, near Crieff, some at Dunkeld, and the remainder he carried home; where some have been cut, within these few years, of a great size. The four left at Monzie are in full vigour; the largest, nearly twelve feet in circumference, at three feet and a half above the ground. Those left at Dunkeld are also in full vigour. Some were placed in a greenhouse, but not thriving, were turned out; one of which is about twelve feet in girth, at three feet and a half above the ground, and is computed to contain four loads of solid timber, or two hundred feet. The largest measured, in 1819, eighty-nine feet in height. At one foot 
from the ground, it girthed seventeen feet eight inches; at three feet, twelve feet seven inches; at ten feet, ten feet four inches; at twenty feet, nine feet seven inches; at forty feet, seven feet eleven inches; at sixty feet, four feet eight inches ; at seventy feet, three feet two inches. It contained three hundred feet, or six loads of timber.

Some years elapsed after these trees were planted before any more larches were set at Dunkeld. A few, however, were planted at Blair in that interval. But the larches planted between the years 1740 and 1750 were inconsiderable in point of number; for the planting of the rocky mountains round Dunkeld, with a view to their growing wood, which has since been done, would at that time have been treated as a chimerical idea.

The Duke of Athol has now been in the habit of cutting larch timber, for different purposes, for thirty years; and as yet, he says, he has met with no instance to induce him to depart from the opinion,- - that larch is the most valuable acquisition, in point of useful timber, that has ever been introduced into Scotland; and he states, that he has cut and used larch from fifty to sixty years' growth, and that the small larch which were thinned out of plantations, were used for 
upright paling, rails, and hurdles. Those fit for sawing, were sawn through the middle; the smaller used round, with the bark on, and proved more durable than oak copse-wood of twenty-four years' growth.

Boats built of the larger timber have been found sound, when the ribs, made of oak forty year's old, were decayed; and we find that the Duke has for some years past had all his ferry and fishing-boats built of larch.

In mill-work, and especially in mill-axles (where oak only used formerly to be employed), larch has been substituted with the best effect. In cutting up an old decayed mill-wheel, in 1818, those parts of the watercogs, \&c., which had been repaired with larch about twenty years before, though black on the surface, on the hatchet being applied, were found as sound and fresh as when put up.

There is not a sufficient quantity of larch, of fit growth, to bring that wood into general use for common purposes; but such as has been cut and sold, has brought two shillings per foot; in some instances more. In the year 1812, the Duke of Athol sold a larch-tree, of fifty year's' growth, for twelve guineas; and at the same time he was offered twenty pounds for another, which he declined cutting. In 1818, he cut twenty larch-trees from a clump 
where they stood too thick, but left the finest trees standing; for these twenty trees his Grace received one hundred guineas, being at the rate of two shillings per foot. The largest of the twenty trees measured one hundred and five feet in length, five feet eleven inches in girth, at four feet from the ground, and contained ninety-four square feet of timber. One of the trees measured one hundred and nine leet in length; but being drawn up by standing too close, did not contain so much solid wood as the first.

The lower range of the Grampian Hills, which extend to Dunkeld, are in altitude from one thousand to one thousand seven hundred feet above the level of the sea ; and a range of mountains, one thousand two hun.dred feet above the level of the sea, is now planted with larch. 'They are in general barren and rocky, composed of mountain schist, slate, and ironstone. Up to the height of twelve hundred feet, larches are planted, and grow luxuriantly; where the Scotch fir, formerly considered the hardiest tree of the north, cannot rear its head. In considerable tracts where fragments of shivered rocks are strewed so thick that vegetation scarcely meets the eye, the larch puts out as strong and vigorous shoots as are to be found in the valleys below, or in the most sheltered situations. 
The Duke of Atholl had planted about a thousand Scotch acres on similar mountains, in 1819, and which has been continued since, placing Scotch fir only in the wet grounds, where larch will not grow, and mixing spruce on the highest points, finding from experience that that tree is next in value to the larch, and thrives in alpine situations almost equally well.

We are informed by his Grace, that of all the larch he has had cut, he has never met with one instance of decay. But that he has seen larch cut in wet situations and tilly soil, on low moors, which, at forty years of age, were decaying at the heart. The larch is certainly an alpine tree, and does not thrive in wet situations.

The comparative value of larch and Scotch fir is such, that when the Duke of Atholl sold a larch of fifty years' growth for twelve guineas, a fir of the same age, and in the same soil, brought only fifteen shillings.

The larch, from being a deciduous tree, is never broken by snow, and very seldom torn by the winds; whilst a heavy fall of snow will destroy, in one night, and break down sometimes more than a third of a fir plantation. 


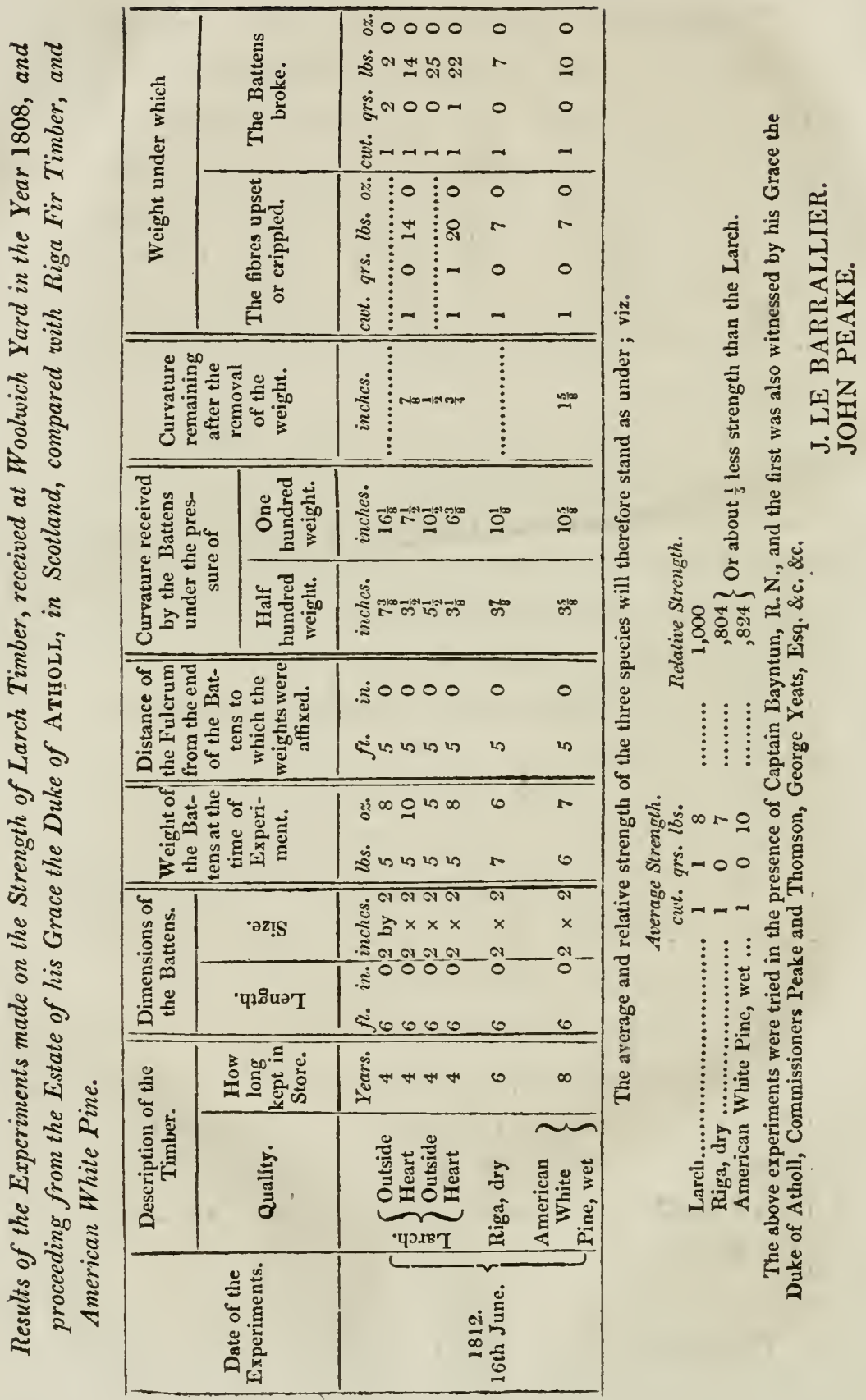


Results of Experiments, on the transverse Strength of Timber, made at Mr. Atkinson's, Grove End, St. John's Wood, on Thursday, March 12th, 1818.

The pieces were each an inch square, except No.3., which was only 8-10ths of an inch in breadth. The numbers in the Table show the weights it would have borne if it had been an inch square; the pieces were supported at each end, and were loaded by putting $5 \mathrm{Ibs}$. at a time into a scale suspended from the middle; - the distance between the supports 30 inches.

\begin{tabular}{|c|c|c|c|c|c|c|}
\hline $\begin{array}{c}\text { Description of } \\
\text { Timber. }\end{array}$ & $\begin{array}{l}\text { No. 1. } \\
\text { Nenel } \\
\text { Timber. }\end{array}$ & $\begin{array}{l}\text { No. } 2 . \\
\text { Red } \\
\text { Larch. }\end{array}$ & $\begin{array}{c}\text { No. } 3 . \\
\text { Red } \\
\text { Larch, old } \\
\text { and very } \\
\text { dry. }\end{array}$ & $\begin{array}{l}\text { No. } 4 . \\
\text { English } \\
\text { Oak. }\end{array}$ & $\begin{array}{l}\text { No. } 5 . \\
\text { English } \\
\text { Oak. }\end{array}$ & $\begin{array}{l}\text { No. } 6 . \\
\text { Riga } \\
\text { Timber. }\end{array}$ \\
\hline $\left.\begin{array}{l}\text { Compar. stiffness - } \\
\text { or the weight that } \\
\text { bent each piece } \\
\text { half an inch }\end{array}\right\}$ & 145 lbs. & $80 \mathrm{lbs}$. & 93 lbs. & $60 \mathrm{lbs}$. & 65 lbs. & 125 lbs. \\
\hline $\left.\begin{array}{l}\text { Compar. strength- } \\
\text { or the weight that } \\
\text { broke each piece }\end{array}\right\}$ & $212 \mathrm{lbs}$. & 253 lbs. & 295 lbs. & 222 lbs. & $231 \mathrm{lbs}$. & 212 lbs. \\
\hline $\left.\begin{array}{l}\text { Compar. extensibi- } \\
\text { lity - or the space } \\
\text { through which the } \\
\text { middle had bent at } \\
\text { the time of fracture }\end{array}\right\}$ & 2.25 inch. & 3 inches. & 2.75 inch. & $2 \cdot 5$ inches & $1 \cdot 4$ inch. & 1.3 inch. \\
\hline $\left.\begin{array}{l}\text { Weight of a cubic } \\
\text { foot of each kind } \\
\text { of timber in the } \\
\text { nearestwhole num- } \\
\text { ber }\end{array}\right\}$ & 34 lbs. & 40 lbs. & 31 lbs. & 41 lbs. & 46 lbs. & $30 \mathrm{lbs}$. \\
\hline Remarks. & $\begin{array}{l}\text { Broke } \\
\text { short. }\end{array}$ & $\begin{array}{l}\text { Splin- } \\
\text { tered. }\end{array}$ & $\begin{array}{l}\text { Broke } \\
\text { short. }\end{array}$ & $\begin{array}{l}\text { Broke } \\
\text { short. }\end{array}$ & $\begin{array}{l}\text { Splin- } \\
\text { tere } d\end{array}$ & $\begin{array}{l}\text { Broke } \\
\text { short. }\end{array}$ \\
\hline
\end{tabular}

As the strength of small pieces depends much on the position of the annual rings, the pieces were placed as nearly alike in this respect as possible. When the pieces were in the position in which they were broke, the dark lines or portions of the annual rings that appear in the section of a piece were vertical. - From the results exhibited in the preceding Table, it appears very clearly, that Larch is best adapted to resist the force of a body in motion;-but to leave no doubts in this respect the following experiments were made. 


\section{Experiments on the Resilience of Timber.}

The pieces were each an inch in depth, and laid upon supports thirty inches apart. The weight fell between two vertical guides (similar to a pile engine), upon the middle of the piece.

\begin{tabular}{|c|c|c|c|c|c|}
\hline $\begin{array}{l}\text { No. of } \\
\text { Exper. }\end{array}$ & $\begin{array}{l}\text { Description of } \\
\text { Timber. }\end{array}$ & $\begin{array}{l}\text { Breadth } \\
\text { of the } \\
\text { Piece. }\end{array}$ & Weight. & $\begin{array}{c}\text { Height from } \\
\text { which the } \\
\text { Weight fell. }\end{array}$ & Effects. \\
\hline No. 7. & $\left\{\begin{array}{c}\text { Oak, same kind } \\
\text { as No. } 4 .\end{array}\right\}$ & 1 inch. & 7 lbs. & 48 inches. & Broke. \\
\hline No. 8. & $\left.\begin{array}{l}\text { Larch, same kind } \\
\text { as No. } 2 . \\
\text { The same } \\
\text { The same } \\
\text { The same } \\
\text { The same } \\
\begin{array}{c}\text { The same,convex } \\
\text { side upwards }\end{array} \\
\text { The same }\end{array}\right\}$ & $\begin{array}{c}\text { I } \text { inch. } \\
\cdots \ldots \ldots \ldots \\
\cdots \ldots \ldots \ldots \\
\cdots \ldots \ldots \ldots \\
\cdots \ldots \ldots \ldots\end{array}$ & $\begin{array}{c}7 \text { lbs. } \\
\ldots \ldots \ldots \ldots \\
\cdots \ldots \ldots \ldots \\
\cdots \ldots \ldots \ldots \\
\cdots \ldots \ldots \ldots\end{array}$ & $\begin{array}{ll}48 & \text { do. } \\
54 & \text { do. } \\
60 & \text { do. } \\
66 & \text { do. } \\
72 & \text { do. } \\
72 & \text { do. } \\
42 & \text { do. }\end{array}$ & 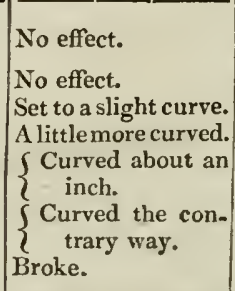 \\
\hline No. 9. & $\left.\begin{array}{l}\text { Larch, same kind } \\
\text { as No. } 3 . \\
\text { The same }\end{array}\right\}$ & $\begin{array}{l}0.8 \text { inch. } \\
\ldots \ldots \ldots \ldots\end{array}$ & $\begin{array}{c}7 \mathrm{lbs} . \\
\ldots \ldots \ldots \ldots\end{array}$ & $\begin{array}{ll}48 & \text { do. } \\
54 & \text { do. }\end{array}$ & $\begin{array}{l}\text { No effect. } \\
\text { Broke. }\end{array}$ \\
\hline No. 10. & $\left.\begin{array}{l}\text { Oak, same kind } \\
\text { as No. } 5 . \\
\text { The same }\end{array}\right\}$ & $\begin{array}{c}1 \text { inch. } \\
\ldots \ldots \ldots \ldots\end{array}$ & $\begin{array}{c}7 \text { lbs. } \\
\cdots \ldots \ldots \ldots\end{array}$ & $\begin{array}{ll}48 & \text { do. } \\
54 & \text { do. }\end{array}$ & $\begin{array}{l}\text { No effect. } \\
\text { Broke. }\end{array}$ \\
\hline No.11. & $\begin{array}{l}\text { English Oak } \\
\text { The same }\end{array}$ & $\begin{array}{c}1 \text { inch. } \\
\ldots \ldots \ldots \ldots . . .\end{array}$ & $\left|\begin{array}{c}7 \mathrm{lbs} . \\
\ldots \ldots \ldots \ldots \ldots\end{array}\right|$ & $\begin{array}{ll}54 & \text { do. } \\
60 & \text { do. }\end{array}$ & $\begin{array}{l}\text { No effect. } \\
\text { Broke. }\end{array}$ \\
\hline
\end{tabular}

No. 11 was a dark-coloured and apparently very strong piece of wood; specific gravity 0.872 or $54 \frac{1}{2} \mathrm{lbs}$. per cubic foot. * On the whole, then, it appears, that Larch is superior to oak in stiffness, in strength, and in the power of resisting a body in motion (called resilience): and it is inferior to Memel or Riga timber in stiffness only.

I am, Sir, yours, \&c.

\section{THOMAS TREDGOLD.}

Grove End, March 16, 1818.

* These experiments were made in the presence of His Grace the Duke of Atholl, Lord Prudhoe, Lord James Murray, John Deas Thomson, Esq., William Adair, Esq., Mr. Geo. Bullock, and Mr. Atkinson, architect to the Ordnance. 


\section{IN D EX.}

Acacia, i. 39. By whom introduced, 42. Use of the timber, 44. Where to be planted, 45. How propagated, 47.

Age, old, the emblem of, i. 259.

Alder, i. 60. Its ancient use, 61. Where to be planted, 63.

65. Use of the timber, 64. 66. Medicinal properties, 67. How propagated, 68.

Alexander the Great, anecdote of, ii. 262.

America, the importance of the discovery, ii. 64. Its effect on the system of botany, i. 41 .

Amiability, the emblem of, i. 309.

Apollo's temple by whom robbed, i. 110 .

Arbor vitæ, i. 51. Great quantity at Père la Chaisc, 54. Use of the wood, 56. Medicinal properties, 57. How propagated, 58 .

Arbutus, i. 69. Its ancient name, 70. Its flowers adapted to the season, 73. Soil, 74. How propagated, 75. 77.

Archers, ancient, ii. 279.

Ash, i. 79. Fabulous account of, 80. Used for spears, $i b$. Serpents will not approach it, 82. Superstition respecting the ash, 83. Situation, 84. Profit of the wood, 86. Of great size, 89. Used for fodder, 91. How propagated, 95.

— weeping, i. 95.

- manna, i. 96.

Aspen, i. 102. Its tremulous nature accounted for, $i l$. Superstition respecting, 103. Use of the timber, 104. Atholl, the Duke of, his plantation of larch, ii. 17. 
Bachelor, the origin of the name of, i. 114.

Bay, i. 106. Why named laurus, 107. Superstition respecting, 108. Thought to purify the air, $i b$. Wliy named nobilis, 113. Used to crown poets, 114. Its early use in England, 116.

— tree at Virgil's tomb, 117. Situation, 118. How propagated, 121.

Beauty, the emblem of, ii. 149.

Birch, i. 123. Origin of the nanie, 124. Natural climate, 125. Ancient use of the bark, 126. Reflections caused by this tree, 128. Situation and use of the timber, 131.

- wine, 130.

Bird cherry, i. 134. Use of the fruit, 136.

Bladder senna, i. 138. Good to fatten sheep, 140. Medicinal quality, $i b$. Native soil, 141.

Bond of love, the emblem of, i. 294.

Botany, the pleasure of this study, i. 72.271.

Box-tree, i. 144. Native soil, 145. Use of the wood, 146. Used to colour hair, 148. Soil and situation, 150.

Broom, i. 151. Situation, 153. Uses of, 156. Medicinal properties, 159. Use in veneering, 160.

Butcher's broom, ii. 309. Natural history of, 310. Qualities, 311.

Cassine, evergreen, i. 291.

Cedar of Lebanon, i. 162. Planted by the Jews, 164. Antiquity of its use, 165. Durability of, 167. Used to preserve writings, $i b$. Character of, 168 . When introduced, 169. Remaining at Libanus, 172. Natural history of, 175 . Thought to purify the air, and inspire religious thoughts, 176. Soil and situation, $i b$.

Chaste love, the emblem of, i. 41 .

Churches, why decorated with holly at Christmas, i. 281.

Clematis. See Virgin's Bower.

Clipping of trees, by whom introduced, i. 302.

Cornel, i. 179. Ancient and modern use of, 182.184. Situation, 185.

Cornelian cherry, i. 185. The fruit described, 187. 
Coquetry, the emblem of, ii. 75 .

Cypress, i. 188. Fabulous account of, 189. Why planted by the Turks, 190. Singular use of a cypress-tree, 191. Native soil and durability, 192. Ancient use in building ships, 194. Where first noticed in England, 196. Where to be planted, 199. 201. How propagated, 203.

Danger, the emblem of, ii. 207.

Daphnephoria, origin of the festival, i. 111.

Darius, anecdote of, i. 227.

Diana, the origin of her temple, i. 229.

Dogwood, i. 179.

Edda of Woden, allegory from, i. 81.

Eglantine, ii. 169.

Elegance, the emblem of, i. 48.

Elm, i. 205. Thought not to be a native, 207. Ancient use of, 209. Why planted in the church-yards of France, 211. Forms the principal boulevards of France and Spain, 211. Great size of, 213. 216. When planted in St. James's Park, 215. Beauty of, 216. Varieties of, 219. Use of the timber, 220.

Evaporation of leaves, i. 98.

Evergreens, remarks on planting, i. 198.

Fashion, her influence in planting, ii. 53.

Fir, i. 225. Natural history of, 226. To whom dedicated, 228. 231. Native soil, 233. Why named fir, 234. Not to be pruned, 236. Situation, 237. Use of the timber, $i 6$. Good for fodder, 239. silver, i. 241.

— hemlock, i. 246. balm of Gilead, i. 245 .

-- spruce, ii. 211.

Flowers, how doubled, i. 258.

-

- the drawing of, recommended as the proper study for females, i. 11 .

Forsaken, the, the emblem of, ii. 44.

Foresight, the emblem of, i. 280.

Friendship, the emblem of, i. 326. 
Furze, i. 274. Native climate, 248. Planted for effect, 249, Its use, 251.

Game-laws, remarks on, i. 253.

Gardens, their delight, i. 10. of the ancients, i. 12. of Babylon, i. 13. of England, the ancient, i: 16.

Gardening, the modern taste introduced, i. 17 .

German flutes, observations on, i. 148.

Gorse, i. 247.

Gray's Inn Gardens, by whom planted, i. 214.

Groves, sacred, i. 231.

Guelder rose, i. 256. Derivation of the name, 258. Soil, $i b$. Situation, 26.

Gum cistus, ii. 312. Natural history of, 313. Situation, 316. Halifax, why so named, ii. 306.

Hawthorn, i. 260. Ancient use of the flowers, 261. Superstition respecting, 263. Use in rural economy, 268. Seeds how to be sown, $i b$. Where to be planted, 270. 272 . with double flowers, i. 267. with yellow berries, i. 270 .

Heath, i. 274. Situation of, 276. Species, 277. Use in domestic economy, 278.

Holly, i. 280. Why used to decorate churches, 281. Derivation of the name, 282. Superstition respecting, $i b$. Varieties of, 285. Recommended for hedges, 286. Situation and soil, 288. Use of the wood, 289. Natural history, and how propagated, $i b$.

Honey, how procured in ancient times, i. 158.

Honey-dew, i. 98.

Honey-suckle, i. 293. Derivation of the name, 295. Varieties of, 297. Soil and situation, 298.

Hope, the emblem of, i. 261.

Hornbeam, i. 301. Soil and situation, 306.

Hospitality, the emblem of, 281.

Ivy, i. 323. Greatly regarded by the ancients, 324. Crowns of, by whom worn, 324. 326. Its supposed antipatly to the vine accounted for, 328 . 
Ivy, not a parasitical plant, 330. Its effects on timber, 331 . On houses, 332. Natural history, 334. How propagated, 336. Use of the root, 335 .

Jasmine, i. 309. Tuscan tale respecting, 311. Recommended for cottage-gardens, 315. How propagated, $i b$. yellow, when introduced, i. 316.

Judas-tree, i. 318. Description of, 320. How propagated, 321.

Laburnum, ii. 1. Where to be planted, 4. Use of the wood, 5. 7. Hares and rabbits, their fondness for, 6. How propagated, 7 .

Ladanum, how obtained, ii. 314.

Larch, ii. 8. Esteemed by the ancients, 9. Great size of a tree seen at Rome, 10. Native place, 11. Fabulous origin of, $i b$. Natural history of, 13. When first planted in this country, 14. The planting encouraged, 16. Frigate built of, 17. 19. Extensive plantations of, 17. 317. Its beauty in furniture, 18. Its increase, 20. It resists the flames, 10. 22. Durability, 23. Used by artists, 25. Improves the ground, 27. Size and value of those cut by the Duke of Atholl, 319. At what altitude planted in Scotland, 320. Comparative value with the Scotch fir, 321. Experiments on the strength of the timber, 323 .

Laurel, ii. 28. When known in Europe, 29. Native place, 32. Poisonous quality, 33. A hill planted with, 35. How propagated, 36. Medicinal properties, 37.

$\longrightarrow$, of great size at Stanmer, ii. 36.

Laurestine, ii. 39. Native place, 40. Where to be planted, 41.

Lilac, ii. 43. Hardy nature, 45. Why named syringa, 46. When introduced into Europe, 4.5. Where to be planted, 50. How propagated, 52.

$\longrightarrow$, Persian, ii. 50.

$\longrightarrow$, Chinese, ii. 51.

Lime or linden, ii. 53. The bark used to write on, 54. Native soil, 55. Great size of, 57. Use of the timber, 59. How propagated, 63.

Louis XIV., anecdote of, i. 120. 
Love, the emblem of, ii. 88.

Magnolia, ii. 64. Why so named, 67. Description of, 65 . When introduced, 67. Fine trees at Goodwood, 68. Species of, 69.

Manna-ash, where indigenous, i. 96.

Manna, its nature, i. 97. How gathered, 99. Why so called, 101.

Maple, ii. 71. The wood esteemed by the ancients, 72 .

May-day, festival of, i. 264.

Melancholy, the emblem of, ii. 261.

Memory, the emblem of, ii. 228.

Mezereon, ii. 75. Native place, 77. Medicinal properties, 80.

Mock orange, ii. 228.

Mnuntain-ash, ii. 83. Ancient use of, 84. Use of the fruit, 86.

Myrtle, ii. 88. Ancient use of, 89. Wreath of, when first worn, 91. Used as spice, 92. Native climate, 92. Fabulous account of, 88. 92. When introduced, 94. Of great age in England, 95. Loves the sea air, 96. Soil and propagation, 98.

Nectary of flowers, its use, i. 295.

Nettle, greatly esteemed in Egypt, i. 55.

Ornamental plantations, their advantage, ii. 110.

Osier, ii. 274. Propagation and situation, 275.

Parks, antiquity of, i. 18.

Passion-flower, ii. 100. Superstition respecting, 101. How propagated, 106. Its fruit, $i b$.

Père la Chaise, noticed, i. 199., and ii. 159.

Perfumes, noxious to animals, i. 167.

Peter the Great, anecdote of, i. 286.

Pheasants, their native place, i. 139.

Pine, ii. 108. Prospers in poor soil, 109.

- Weymouth, when introduced, ii. 111. Where to be planted for ornament, 112. Law made respecting, ib. Soil, 113.

Pine garlands, to whom awarded, i. 230. 
Plane, ii. 114. Regarded by the ancients, 115. Great size of, 117. When introduced, 119. Not subject to blight, 121. Endures the smoke of London, 122. Soil, 123.

Plantations, remarks on, i. 20. 35. of larch, ii. 17.

Planting commendable, ii. 213.

Plants, native, love of, i. 8 .

- growing in singular situations, i. 331. - their various means of climbing, i. 25.

Pleasure-gardens, beneficial to health, i. 2.

Poet-laureat, why so called, i. 114.

Poplar, ii. 124. Garlands of, by whom worn, 125. Native soil, 127.

Po, or Lombardy, when introduced, 129. Planted by the peasants in Naples, 130. Use of the wood, 131. Quick growth, 133.

Portugal broom, i. 155.

— laurel, ii. 136. Fruit good for pheasants, 138. Hardy nature, 140. How propagated, $i b$.

Privet, ii. 142. Situation, 143. 147. Use of the fruit, 144. 146, 147. Thrives in the smoke of London, 143.

Profit obtained by planting ash-trees, i. 86 . oaks, i. 88 firs, i. 238. 245.

Ptolemy Philopater, anecdote of, i. 327.

Quicksets, i. 268.

Rhododendron, ii. 202. Poisons honey, 203. When intro. duced, 204. How propagated, 207.

Richard the Second, anecdote of, ii. 281.

Rogation-week, why so called, i. 133.

Rose, ii. 148. Noticed by oriental poets, 152. Otto of, how discovered, 153. Fabulous account of, 154. Etymology of its name, 157. Why used as a symbol of silence, 156 . Greatly used by the ancients, 157. Planted on graves, 158. Used in religious worship, 161. Consecrated rose sent to Henry the Eighth, 162. Superstition respecting, 164. Use in floral language, 166. Formerly precious in France, 167. Number of varieties, 168. Native species, 169. 
Rose, dog, why so named, ii. 170. Used to graft on, 171 . white, 173. Why used by the house of York, $i b$.

- Province, 177. Native place, 178. When introduced, 179. Varieties of, $i b$.

- moss, 180. Poetical account of, 182. How propagated, 184.

- hundred-leaved, 184. Native place, 185. Varieties of, 186.

- cinnamon, or May rose, 187.

- musk, 188.

— yellow, 189.

- China, 192.

— Lady Banks's, 194.

Rose-trees, observations on planting, 195. Mode of retarding the flowers, 196. Kinds recommended for forcing, 197.

Rose, its medicinal properties, ii. 200.

—- blight and insects that injure these plants, 198.

Rose, acacia, i. 48. How propagated, 50.

Sacred woods of the ancients, i. 181.

Sea-coast, what trees recommended for, i. 84 .

Shrubbery, ii. 251. Origin of, i. 1. Its utility, 2. Remarks on planting, 26. How embellished, 29.

Silver fir, i. 241. When introduced, 242. Soil, 243.

Solitude, the emblem of, i. 275.

Sorrow, the emblem of, i. 188., and ii. 288.

Spanish broom, i. 153.

Spiræa frutex, ii. 208.

Spruce fir, ii. 211. Early cultivation, 212. Purifies the air, 215.

American, ii. 215.

beer, how made, ii. 216.

Strawberry tree. See Arbutus.

Sumach, ii. 217. When introduced, 218. How propagated, 224.

Sweet briar, ii. 169.

Swiss peasants, their summer-emigration, i. 158.

Sycamore, ii. 221. Noticed by Chaucer, 223. The sap used in beer, 224. Of great size, 225. How propagated, 226. 
Syringa, ii. 228. Domestic use of, 229. Situation, 230. How propagated, 232.

Tamarisk, ii. 247. Superstition respecting, 249. Situation, 251.

Terrific, the general love of, i. 4 .

Tiberius, his dread of lightning, i. 108.

Traveller's joy, ii. 233.

Trees, distinguish remarkable spots, i. 171. Correct a putrid air, 195.

Trumpet-flower, ii. $2360^{\circ}$

Tulip-tree, ii. 240. Great size of, 241. When introduced, 243.

Under the rose, origin of the saying, ii. 156.

Versailles, the garden of, 302.

Vessels or boats, of what anciently composed, i. 61. ii. 269.

Villa, why so called, i. 46.

Virgil, pretended dream of his mother, i. 117.

Virgin's bower, ii. 257. How propagated, 259. Situation, 260. wild, ii. 233.

Virginian creeper, ii. 253. Medicinal properties, 256.

Voluptuous love, the emblem of, ii. 182.

White thorn, i. 260.

Willow, ii. 261. Species of, 267. Ancient use of, ib. Utility of, 272.

—, weeping, by whom introduced, ii. 263. Situation, 265.

$\longrightarrow$, natural history of, 277.

boats of great antiquity, ii. 269.

Wood, when sold by weight, ii. 212.

Woodbine. See Honey-suckle.

Yew, ii. 279. Why planted in church-yards, 282. 285.

Laws respecting this wood, 284. Why considered a funeral tree, 286. Poisonous nature, 290. Fatal to cattle, 293. Natural history, 297. Where found wild, $i 6$. Remarkable yew-trees, 300. Derivation of the name, 305. How propagated, 306. Use of the wood, 307. 
LoNnON:

Printed by A. \& R. Spottiswoode, New-Street-Square. 

